UNIVERSIDEADE DE SÃO PAULO

FACULDADE DE FILOSOFIA, LETRAS E CIÊNCIAS HUMANAS

DEPARTAMENTO DE HISTÓRIA

PROGRAMA DE PÓS-GRADUAÇÃO EM HISTÓRIA SOCIAL

\title{
ÁGORA, DÊMOS E LAÓS : OS MODOS DE FIGURAÇÃO DO POVO NA ASSEMBLÉIA HOMÉRICA \\ - contradições, ambigüidades e indefinições -
}

Alfredo julien

Tese apresentada ao Programa de Pós-Graduação em História Social, do Departamento de História da Faculdade de Filosofia, Letras e Ciências Humanas da Universidade de São Paulo para a obtenção do Título de Doutor em História Social

Orientador: Prof. Dr. Francisco Murari Pires 
Serviço de Biblioteca e Documentação da Faculdade de Filosofia, Letras e Ciências Humanas da Universidade de São Paulo

Julien, Alfredo.

Ágora, dêmos e laós : os modos de figuração do povo na assembléia homérica - contradições, ambigüidades e indefinições / Alfredo Julien ; orientador Francisco Murari Pires. -- São Paulo, 2006.

$214 \mathrm{f}$.

Tese (Doutorado - Programa de Pós-Graduação em História Social. Área de concentração: História Social) - Departamento de História da Faculdade de Filosofia, Letras e Ciências Humanas da Universidade de São Paulo.

1. Homero, 750 a.C. 2. Poesia épica (Crítica e interpretação) - Grécia Antiga. 3. Grécia Antiga (Organização social; História). 4. Cultura grega antiga 5. Hermenêutica. I. Título. 


\title{
FOLHA DE APROVAÇÃO
}

\author{
Alfredo Julien \\ Ágora, dêmos e laós : os modos de figuração do povo na assembléia homérica - \\ contradições, ambigüidades e indefinições
}

Tese apresentada ao Programa de Pós-Graduação em História Social, do Departamento de História da Faculdade de Filosofia, Letras e Ciências Humanas da Universidade de São Paulo para a obtenção do Título de Doutor.

Área de Concentração: História Social

Aprovado em:

\section{Banca Examinadora}

Prof.DR.

Instituição: Assinatura

Prof.DR.

Instituição: Assinatura

Prof.DR.

Instituição: Assinatura

Prof.DR.

Instituição: Assinatura

Prof.DR.

Instituição: Assinatura 
À meu pai (in memoriam) e minha mãe, pela dedicação generosa e abnegada, raízes de tudo que construí. 


\section{AGRADECIMENTOS}

Pela dedicação generosa, tanto em sala de aula ministrando cursos sempre fecundos, como em tantos outros momentos, muitas vezes não formais, nos quais o papel de amigo, mestre e professor reuniam-se em sua pessoa. Pelos conselhos e ensinamentos. Pelo conhecimento da língua de Homero, que neste trabalho me foi tão útil. Por todas as conversas que tivemos, agradeço ao professor Henrique Murachco: ponto de partida desse percurso acadêmico.

Atenção especial também registro ao meu professor orientador Francisco Murari Pires pela paciência, confiança e, principalmente, pela philia com a qual me abrigou. Obrigado pela orientação, graças a qual pude seguir meu caminho. Muito desse trabalho é o resultado da leitura pessoal que tive de suas aulas, comentários e textos.

Agradeço também à professora Maria Luiza Corassim e ao professor André Malta Campos pelas sugestões apresentadas no exame de qualificação. A atenção que dispensaram à minha pesquisa e os comentários construtivos e generosos foram importantes para a cristalização deste trabalho.

Ao professor Anito Steinbach, agradeço pela revisão textual, mas de antemão declaro que se incorreções ainda persistem a responsabilidade é do autor, que não apresentou o texto todo para a revisão e exigiu prazo mínimo para a feitura do trabalho. Agradeço pelo trabalho e pelas noites acordado que destinou a esta tese. 
Agradeço à Universidade Federal de Sergipe, em especial ao Departamento de História, pela paciência e solicitudes demonstradas sempre que necessário. Aos meus alunos, de todos os tempos, pela experiência que me proporcionaram. Ao pessoal da biblioteca central da Faculdade de Filosofia, Letras e Ciências Humanas, como também ao das secretarias da pós-graduação, pelo atendimento sempre gentil e prestativo.

E de forma especial, pelo afeto e carinho que envolve, agradeço a Amanda, minha esposa querida, e ao Neto, o filho que a vida me trouxe de presente, pelo companheirismo diário e pelo prazer da vida. Devo muito a eles, inclusive a escolha da epígrafe que abre esse trabalho.

Enfim agradeço a todos os amigos que permitiram a experiência do diálogo, tão necessária ao exercício do pensamento, em especial, à France e Juvino. 


\section{VERDADE}

A porta da verdade estava aberta, mas só deixava passar meia pessoa de cada vez.

Assim não era possível atingir toda a verdade, porque a meia pessoa que entrava só trazia o perfil de meia verdade.

E sua segunda metade voltava igualmente com meio perfil. E os meios perfis não coincidiam

Arrebentaram a porta. Derrubaram a porta.

Chegaram a um lugar luminoso onde a verdade esplendia seus fogos.

Era dividida em metades

diferentes uma das outras.

Chegou-se a discutir qual a metade mais bela. Nenhuma das duas era totalmente bela.

E carecia optar. Cada um optou conforme seu capricho, sua ilusão, sua miopia 


\section{RESUMO}

JULIEN, A. Ágora, dêmos e laós: figurações do povo na assembléia homérica contradições, ambigüidades e indefinições. 2006. 214 f. (Tese de Doutorado) Faculdade de Filosofia, Letras e Ciências Humanas da Universidade de São Paulo, São Paulo, 2006.

Na epopéia homérica, a ágora, a assembléia do povo, constitui espaço privilegiado de interação social, servindo de cenário para a figuração de eventos importantes para a condução da trama, tanto da llíada quanto da Odisséia. No âmbito dos estudos homéricos, aqueles que se dedicam à análise histórica dos poemas têm feito largo uso desses episódios, na busca de chegar a explicações coerentes a respeito dos modos de operação da sociedade retratada na narrativa. Qual seria o papel das assembléias na sociedade homérica? Qual seria a constituição social do povo presente nessas reuniões? Seria ela conformada aos moldes de uma sociedade de caráter patriarcal ou refletiria as instituições das nascentes póleis arcaicas? Ou seria pura ficção, um amálgama de elementos contraditórios, não retratando uma sociedade que tivesse tido existência fora dos textos?

O principal obstáculo para o encaminhamento dessas questões encontrase na própria natureza dos textos homéricos. Elas são caras à nossa forma de perceber o mundo, mas não encontram eco no texto. Os poemas não apresentam registros que possibilitem respostas precisas para elas. Quando as questões que animam a interpretação buscam a clara delimitação das instâncias organizacionais da sociedade figurada na llíada e na Odisséia, a 
memória preservada, no registro épico da ágora homérica, apresenta-se para nós permeada de ambigüidade e indefinições, que, para serem rompidas, necessitam de esquemas de referências que possibilitem contextos a partir dos quais se possa empreender a análise.

No presente trabalho, apresentam-se reflexão sobre a forma como a crítica especializada tem contornado tais problemas de interpretação e proposta de hermenêutica das cenas de assembléia na épica, tendo como fio condutor as questões da conformação da ágora como elemento definidor do estatuto da vida civilizada; da oposição entre assunto público e privado; e da natureza social do povo presente nas assembléias

Palavras-chave: Homero. Épica. Hermenêutica. Historiografia. Pólis. 


\begin{abstract}
JULIEN, A. Ágora, dêmos e laós: portraits of the people in Homeric assembly contradictions, ambiguities and unclear settings. 2006. 214 f. (Doctoral Thesis) - Faculdade de Filosofia, Letras e Ciências Humanas da Universidade de São Paulo, São Paulo, 2006.
\end{abstract}

In Homeric epic poems, the ágora, the assembly of the people, constitutes a privileged space of social interaction. It serves as stage set for portraying important events for plot conduction, both in the Iliad and the Odissey. In scope of Homeric studies, those engaged in historical analysis of the epic poems have made wide use of these episodes in search of coherent explanations, regarding the operational ways of the society portrayed throughout the narrative. Which would be the role of the assemblies in the Homeric society? Which would be the social constitution of the people present in these meetings? Would it be conformed to the moulds of a society of patriarchal character or would it reflect the institutions of the rising archaic pólis? Or would it be pure fiction, an amalgam of contradictory elements, not portraying a society that had had existence out of the texts?

The main obstacle for the guiding of these questions meets in the proper nature of the Homeric texts. They are so dear to the way we perceive the world, but they don't find any echo in the text. The poems do not present registers that make possible accurate answers for the asked questions. When the questions that liven up the interpretation search the clear delimitation of the organizational instances of the society depicted in the Iliad and in the Odyssey, the memory 
preserved in the epic register of the Homeric ágora comes out pervaded by ambiguity and unclear settings, that, to be breached, need design of references that make possible contexts from which the analysis can be undertaken. This work presents a reflection on the form as the specialized critic has contoured such problems of interpretation and a proposal of hermeneutics of the assembly scenes in the epic, having as conducting wire the questions related to the conformation of the ágora as defining element of civilized life; the opposition between public and private subject; and the social nature of people present in the assemblies.

Keywords: Homer. Epic. Hermeneutics. Historiography. Pólis. 
1 - INTRODUÇÃO 


\section{1- Introdução}

Local de encontro da comunidade, a agorá talvez seja um dos espaços mais emblemáticos da cultura grega antiga. Lugar de trocas, deliberações e debates. Espaço cívico do exercício da palavra, no qual, pela primeira vez, muito dos questionamentos políticos e filosóficos que hoje compõem a alma ocidental receberam algum tipo de equacionamento.

A palavra grega agorá é utilizada para denominar tanto o espaço físico constituído pela praça pública, como o social representado pelas assembléias deliberativas da comunidade. Segundo Chantraine (1968), agorá é o nome da ação referente ao verbo agueíro, reunir. Em grego alfabético significaria "assembléia do povo" e, também o local em que se realizava essa assembléia. Claude Mossé (2004, p.32) observa que desde a fundação das primeiras cidades coloniais, no século VIII, nelas se reservava um lugar para a futura agorá: local em que se cruzavam as principais vias e, freqüentemente, era erguido um túmulo em honra ao fundador da cidade.

A assembléia é amplamente empregada no esquema de composição da narrativa homérica como espaço de interação social, não se caracterizando por um

\footnotetext{
1 Embora tenhamos empregado a forma transcrita "ágora" em nosso título, no copo do texto utilizaremos a forma grega transliterada, mantendo o acento na forma e no local em que se encontra no grego. Ver Murachco, 2001, p.41 .
} 
elemento marginal que aparece de forma isolada em alguns momentos da narrativa. Sua ampla utilização remete à familiaridade com que Homero tratava sua existência. A sociedade retratada por ele tem na assembléia um de seus principais eixos de organização. Local de celebrações cívicas, de discórdias desintegradoras e de pacificação de contendas.

$\mathrm{Na}$ llíada, aqueus e troianos organizam dez assembléias. Em todas figuram situações relevantes, pontuando a condução da trama. Na primeira ${ }^{2}$, figuram os episódios que dão início à narrativa e levam a querela entre Agamêmnon e Aquiles. Nela, Agamêmnon recusa o pedido de resgate feito por Crises, sacerdote de Apolo, em prol da libertação de sua filha que estava cativa do Atrida. Como conseqüência, ofendido, o sacerdote recorre ao deus, que, então envia a peste avassaladora ao acampamento aqueu. Diante da mortandade, Aquiles convoca uma assembléia, a segunda ${ }^{3}$. Nela, Calcas, o adivinho, diz que a causa do flagelo fora a ofensa de Agamêmnon, e que o deus só aplacaria sua cólera se a cativa fosse entregue ao seu pai. Agamêmnon aceita restituí-la, porém exige que os aqueus the concedam outro prêmio, fornecendo-Ihe outra escrava. Aquiles, buscando demovê-lo dessa idéia, discute com ele. A contenda resultou nefasta. Aquiles retira-se dos combates e pede à sua mãe, a deusa Tétis, que interceda junto a Zeus, para que seja vingado. Zeus aquiesce e, maquinando um plano, incita Agamêmnon, por intermédio de um sonho, a reiniciar os combates aos troianos. Então, de manhã, o Atrida levanta-se e

\footnotetext{
2 llíada. 1.17-52.

${ }^{3}$ llíada. 1.53-307.
} 
convoca uma assembléia ${ }^{4}$, a terceira. A reunião foi tumultuada. Nela, Agamêmnon, em uma estratégia controvertida e muito debatida pela crítica, propõe a retirada, motivando a debandada dos homens em direção às naus. É Odisseu quem convence a tropa retornar. Ao final, os aqueus estão novamente determinados a retomar os combates. Então, se reagrupam e avançam em direção à cidadela de Tróia. Os troianos recebem a notícia do ataque reunidos em assembléia, a quarta ${ }^{5}$, e se preparam para a luta. Quando cessam os combates desse dia, reunidos em uma assembléia, a quinta ${ }^{6}$, os troianos elaboram uma proposta de paz. Os aqueus recebem-na e rejeitam-na, também reunidos em uma assembléia, a sexta ${ }^{7}$. Ao final do segundo dia de batalha, aqueus e troianos novamente reúnem suas assembléias. Em uma delas, a sétima ${ }^{8}$, Heitor promete destruir os aqueus. Ao mesmo tempo, na outra, a oitava, em um momento de desespero, Agamêmnom propõe a fuga ${ }^{9}$, desta vez recusada. Ao final do terceiro dia de batalha, quando Pátroclo foi morto, troianos e aqueus reúnem suas assembléias. Entre os troianos, Heitor insistiu em permanecer com suas tropas fora dos muros da cidade e manter o cerco, embora advertido por Polidamas de que não deveria tomar tal atitude, pois Aquiles, em breve, retornaria aos combates para vingar a morte do amigo ${ }^{10}$. Nesse mesmo momento, Aquiles, também em uma assembléia, a décima ${ }^{11}$, comunica aos aqueus que retornaria aos combates, selando, assim, a sorte do líder troiano.

\footnotetext{
${ }^{4}$ Ilíada. 2.41-52; 86-399.

5 Ilíada. 2.786-810.

6 Ilíada. 7.344-380.

7 Ilíada. 7.381-411.

8 llíada. 8.489-411.

9 llíada. 99-88.

${ }^{10}$ llíada. 18.243-313.

${ }^{11}$ Ilíada. 19, 40-ss.
} 
Dispostas em duplas, com paralelismos de conteúdos, as assembléias estão bem articuladas no plano da narrativa, como se pode visualizar de maneira mais clara no quadro sinóptico apresentado abaixo

\begin{tabular}{|c|c|}
\hline $\left.1^{\mathrm{a}}\right)$ ofensa a Crises & $\left.2^{a}\right)$ reparação ao sacerdote e a querela \\
\hline $\left.3^{a}\right)$ aqueus retornam aos combates & $\left.4^{a}\right)$ troianos recebem notícia do ataque \\
\hline $\left.5^{\mathrm{a}}\right)$ proposta de paz troiana & $\left.6^{a}\right)$ aqueus rejeitam-na \\
\hline $\left.7^{a}\right)$ Heitor promete destruir aqueus & 8a) Agamêmnom propõe fugir \\
\hline 9â)Heitor propõe manter cerco & 10ª)Aquiles volta aos combates \\
\hline
\end{tabular}

Nas duas primeiras, são narrados eventos que levam à querela entre Agamêmnom e Aquiles, retratando-se, na primeira, a ofensa a Crises, na segunda, a sua reparação. Nas duas seguintes, Troianos e Aqueus põem-se novamente a lutar. Cada dia de combates termina com uma assembléia realizada de cada lado, nas quais ambos avaliam suas situações e propõem ações para o dia seguinte: manter o ataque, propor a paz ou até a fuga. Na llíada, a assembléia constitui o principal cenário, em que Homero articula suas personagens em situação de convívio social $^{12}$.

\footnotetext{
${ }^{12} \mathrm{Na}$ llíada, outros dois episódios em que se faz referência importante à agorá é o do "Escudo de Aquiles (18.478-608) e um relato Nestor sobre eventos transcorridos em sua juventude (11.670-761).
} 
$\mathrm{Na}$ Odisséia, embora o cenário social, por qual as personagens se movimentam, seja mais variado, a assembléia também é apresentada como um importante espaço de interação. É pela convocação de uma que Telêmaco dá início às suas ações para resolver a questão aflitiva em que se encontrava ${ }^{13}$, pedindo para que os pretendentes abandonassem sua casa e um navio com tripulação, para que pudesse viajar com a finalidade de obter notícias de seu pai. Telêmaco não obtém sucesso completo na reunião. Os pretendentes não abandonam sua casa, porém consegue que Ihe forneçam o navio para a viagem. Ao receberem a informação da partida dele, os pretendentes ficam preocupados. Temem que ele esteja tramando as suas mortes, então planejam matá-lo. É na agorá que os pretendentes se reúnem, após tomarem conhecimento que Telêmaco escapara da emboscada que preparam para ele. É uma reunião restrita, ninguém além deles participa dela. O que eles não sabiam é que Odisseu já se encontrava e meditava uma forma de dar-lhes a morte. Também na agorá de Ítaca, após Odisseu ter consumado sua vingança, os parentes dos que foram mortos clamam por vingança e reúnem forças para lutarem contra ele ${ }^{14}$. Na Odisséia, a agorá não é somente mencionada no cenário de Ítaca. Ela também está presente entre os Feácios ${ }^{15}$ e os Lestrigões ${ }^{16}$, povos fantásticos visitados por Odisseu em suas errâncias, e sua ausência é explicitamente citada entre os Ciclopes.

\footnotetext{
13 Od.2.1-259.

14 Od.24.413-64.

Na Odisséia, a agorá não é somente mencionada no cenário de Ítaca. Ela também está presente entre os Feácios (Od.6.1 - 13.80) e os Lestrigões (Od.10.80-132), povos fantásticos visitados por Odisseu em suas errâncias, e sua ausência é explicitamente citada entre os Ciclopes.

${ }^{15}$ Odisséia $6.1-13.80$.

${ }^{16}$ Odisséia $10.80-132$.
} 
O papel das assembléias na épica chama a atenção dos estudiosos que se dedicam aos aspectos sociais e históricos dos poemas, motivando um intenso debate no qual podemos delinear algumas diretrizes balizando as discussões. Entre elas, destaca-se o interesse pela função das assembléias, no conjunto das instâncias organizativas, e a composição social dos grupos que a freqüentaria. Quais grupos formariam a sociedade homérica? E as assembléias seriam puramente consultivas ou teriam capacidade decisória?

O debate relaciona-se diretamente com a questão da emergência da pólis, buscando responder em que medida elas se aproximariam ou se distanciariam da organização social caracterizada pela cidade estado na Grécia Antiga. Hammer (1998) observa que mesmo um exame superficial nos estudos homéricos revela a visão quase axiomática de que a épica homérica retrataria um mundo pré-político. Segundo ele, tal constatação derivaria da tradição interpretativa de fundo aristotélico, que identificou a Cidade-estado independente como eixo de referência para a reflexão sobre a organização social no mundo grego antigo. Essa tradição ter-se-ia adequado bem ao arcabouço científico-antropológico, trabalhado por inúmeras gerações de classicistas, que enfatiza em suas abordagens da épica homérica a análise de estrutura, função e o desenvolvimento de taxionomias do sistema político e social, desenvolvendo uma noção de política ligada à emergência de estruturas e instituições específicas identificadoras de funções que eram exclusivamente (ou primariamente) políticas. A pólis autônoma, nessa linha de raciocínio, conteria os arranjos institucionais necessários para levar a cabo as funções políticas de alocação de recursos, a imposição de valores e o julgamento das disputas, condições que estariam ausentes na épica. 
Runciman (1982, p.351), fixando a linha evolutiva que, a partir de uma sociedade sem Estado, conduziria ao surgimento do Estado na Grécia Arcaica, estabelece quatro estágios, marcando esse processo: 1) o estágio primitivo original das comunidades sem estado, 2) as sociedades que apresentariam uma organização caracterizada pelo que ele chama de semi-estado, 3) as que apresentariam características do que chama de proto-estado e, finalmente, 4) as sociedades estatais. Semi-estado e proto-estado seriam sociedades que teriam transposto o estágio "sem Estado" das primitivas reuniões de caçadores, pastores nômades, cultivadores de roças, ou das casas patriarcais autônomas, como apresentadas, segundo ele, no mito dos Ciclopes. Porém, as sociedades semiestatais ainda não portariam potencial inerente para o progresso em direção à organização do estado. A proto-estatal sim. Segundo Runciman, a sociedade homérica caracterizar-se-ia por ser semi-estatal, pois ainda não possuiria os elementos que poderiam levá-la à constituição da pólis. Faltar-lhe-iam funções governamentais especializadas, a centralização da força coercitiva, e a organização de estruturas estáveis.

Halverson (1986, p.1-8) observa que a épica não teria dimensão política significativa, pois não conteria nem uma dimensão organizacional nem psicológica da vida comunitária. Para Posner (1979, p.27), Homero retrata uma sociedade prépolítica, caracterizada pela ausência de Estado, na qual a assembléia não constituiria um corpo governamental. Os seus membros teriam o direito de ser ouvido, mas nenhum poder de decisão. Para Finley (1998, p.32), no "Mundo de Ulisses", a assembléia ainda estaria longe de ter condições para executar as funções que exerceu na experiência da pólis clássica. 
A assembléia está no centro do debate sobre a organização social apresentada em Homero. É nela que a comunidade se consubstancia e se manifesta. É na sua forma de funcionamento e do papel que exerce, como instância deliberativa e decisória, que, principalmente, pode-se detectar o nível de organização comunitária que caracterizaria a sociedade retratada nos poemas.

O predomínio da opinião quase axiomática, como diz Hammer, de que a epopéia retrataria uma sociedade pré-política não é um fator que impede o debate e a discussão a respeito do seu papel na épica homérica. Se há concordância a respeito da condição pré-politica que marcaria a sociedade homérica, o mesmo não acontece ao se tentar caracterizar que tipo de sociedade pré-política seria essa, e em que medida ela estaria mais próxima ou mais distante do mundo da pólis. Nesse sentido, as discussões em torno da assembléia homérica assumem um papel capital. Por ser ela uma instância central da organização da cidade estado, é por meio de sua caracterização que se busca determinar as semelhanças e as diferenças que a épica guardaria com a pólis grega. A principal linha de questionamento, orientando a condução desses trabalhos, são as perguntas que se fazem a respeito da função das assembléias no conjunto das instancias organizativas da sociedade homérica e da composição social de seus elementos.

A reflexão que se apresenta nesta pesquisa tem por um de seus objetivos fixar os limites dessa prática hermenêutica, observando que os poemas apresentam formas sociais que não são passíveis de serem delimitadas de maneira clara e precisa e que, por conseqüência, pensar a sociedade homérica em termos de classe social com uma nítida delimitação de suas esferas organizativas, tendo como modelo o mundo clássico, leva-nos a uma aporia que, para ser rompida, necessita de procedimentos analíticos e pressupostos com os quais se possa modelar o que 
se apresenta como indefinido, abrindo, assim, caminho e ditando trilhas pelo terreno movediço do que se convencionou chamar de "sociedade homérica".

Devido às indefinições do texto, os poemas homéricos constituem-se um material difícil de ser apreendido pela interpretação. Terreno fértil que, regado pela multiplicidade de abordagens teórico-metodológicas geradas pelos modernos métodos de análise, permite aos pesquisadores percorrerem sempre novos e variados caminhos. Para quem pretende se debruçar sobre o assunto, tal situação surge como um cenário confuso e de difícil aproximação. É como entrar em um labirinto cujos corredores são formados pela profusão de interpretações existentes sobre o assunto. Labirintos são sempre arriscados! Quando se decide penetrá-los, não é possível antever se obteremos sucesso ou não na empreitada, já que, em razão de opções indevidas, o risco de se perder pelas encruzilhadas é sempre muito grande! Como, então, deveríamos proceder para adentrar em um debate, que aparentemente se mostra inextricável?

Com a figura do labirinto, não queremos dizer que, em meio à diversidade de interpretações, existiria uma verdadeira ou que haveria algum caminho ainda por se desvendar, que se tornaria na chave para o perfeito entendimento das relações sociais na épica. Consideramos que todas elas contribuem com o aumento do conhecimento sobre a estruturação do texto épico, evidenciando seus diversos aspectos. Porém os resultados que produzem não podem ser tomados de forma absoluta. Não acreditamos que de um lado haja as interpretações, errôneas e, de outro, o texto resguardando a sua verdade, resistindo a entregar-se por completo, e que nós possuiríamos as chaves de sua interpretação. Colocamos nosso trabalho como mais um exercício de reflexão sobre a épica, pois, para nós, o conhecimento, 
nesse caso pelo menos, não se encontrará nas respostas e nas conclusões, mas na tomada de consciência do debate em si e nas múltiplas possibilidades que encerra.

Procurando estabelecer os procedimentos metodológicos que orientam os principais vieses de interpretação do texto homérico, nossa pesquisa tem por objetivo refletir sobre essas práticas, com o objetivo de identificar o núcleo comum que as orientam, o ponto a partir do qual os caminhos se abrem para uma multiplicidade de possibilidades de interpretações. Ponto em que a erudição mostra seus limites e a interpretação só pode continuar fundamentando-se na escolha subjetiva e arbitrária. O momento em que a aporia deve ser transposta, para por no seu lugar interpretações racionais, que dotem o mundo homérico de características funcionais e coerentes, delimitando o papel das assembléias e permitindo identificar a origem social dos elementos presentes nelas.

O núcleo de nossas preocupações concentra-se em dois aspectos básicos, trabalhados simultaneamente. De um lado, está-se preocupado em identificar quais são os discursos que se apresentam sobre o tema, procurando delinear como se organizam e como constroem os seus argumentos para atingirem seus objetivos. De outro, procura-se recolocar a questão inicial, a partir da qual a sociedade homérica tem sido estudada, visando delinear novos paradigmas que possam contribuir com o aprofundamento do debate sobre o tema, principalmente no que se refere à questão das representações das práticas sociais. Quer-se entender com quais lentes o mundo homérico tem sido observado, visando, através da compreensão dos diversos pressupostos que balizam seu estudo, transitar com mais facilidade pelos diversos modelos analíticos construídos para entender a sociedade homérica. Buscamos uma hermenêutica que não absolutize, mas que preserve ambigüidades, contradições e indefinições. 
O material básico utilizado para conduzir as questões explicitadas acima é o que se apresenta na Odisséia, ou seja, as três reuniões realizadas na agorá de Ítaca, o episódio dos Feácios e o dos Ciclopes. Referências à llíada somente são feitas com a intenção de proporcionar elementos para a reflexão das questões evidenciadas a partir do texto odisseico. Escolha que é muito mais conseqüência da forma como se configura o debate sobre a constituição da sociedade homérica do que uma seleção posta apriori pelo pesquisador como forma de delimitar o objeto sobre o qual se empreende a análise. A crítica especializada, ao versar sobre a organização da sociedade homérica e o papel da assembléia dentro dela, basicamente elenca esses cinco episódios como evidências sobres as quais se opera a interpretação. Dividimos a exposição de nossa reflexão nos seguintes capítulos:

2 - Olhares e interpretações: as questões de método na hermenêutica das cenas de assembléia na épica homérica.

2.1 - A crítica histórica e a questão da autoria e do processo de composição da épica homérica

2.2 - A crítica histórica e a fixação dos significados de dêmos e laós

\section{3 - A ágora e os limites da vida civilizada}

3.1 - Desmedidos, selvagens e injustos: o tema da ausência de sociabilidade

3.2 - Os Feácios e os modos de vida civilizada

\section{4 - As reuniões na ágora de Ítaca}

4.1 - A Assembléia de Telêmaco

4.2 A Reunião dos Pretendentes

4.3 - A Assembléia da Vingança

5 - Conclusão : A Cena Final

6 - Referências bibliográficas 
No primeiro capítulo, "Olhares e interpretações...", procura-se explicitar de que maneira a crítica historiográfica tem modelado o papel da assembléia no conjunto da sociedade homérica. Quais são os pressupostos metodológicos que orientam a construção de modelos funcionais e coerentes que visam dar conta da organização de se funcionamento.

Tendo como parâmetro que a sociedade homérica é a sociedade que se apresenta nos poemas e não uma sociedade historicamente existente como realidade fora deles, nossa abordagem, nesse capítulo, tem caráter eminentemente desconstrucionista. Nesse sentido é importante explicitar o que entendemos por "sociedade homérica". Partimos do princípio de que ela seja somente a sociedade que se retrata nos poemas, não possuindo existência fora dele. Com isso, é claro, não se pretende afirmar que a sociedade homérica seja uma ficção ou a-histórica. Não nos preocupamos com a dicotomia realidade/ficção.

A circunscrição somente ao âmbito do poema é por motivos metodológicos originados das dificuldades de se relacionar a llíada e a Odisséia a qualquer evidência externa. A épica, como evidência histórica, é um documento isolado em seu contexto de produção, o que torna impossível o seu cotejamento com outras fontes que possam, de maneira conclusiva, solucionar os problemas de interpretação levantados pela crítica. Mas, se a sociedade retratada nos poemas apresenta-se como difícil de ser apreendida, e os contextos sociais, em que as cenas de assembléias se desenvolvem, apresentam-se como indefinidos, como então dar solução aos problemas de interpretação sem apelar para contextos sociais externos ao próprio texto? Se esses contextos têm na própria épica sua principal fonte de informação, como utilizá-los para solucionar os problemas de interpretação levantados sobre a sociedade descrita nos poemas? 
Os métodos empregados na análise dos poemas são variados e não se pretende abordá-los com a intenção de dar conta da multiplicidade de possibilidades que eles oferecem. Seria um trabalho para Hércules. Nesse capítulo, focamos nossa atenção somente em um aspecto específico dessa questão: o dos esquemas de referências com os quais se busca a interpretação das cenas de assembléia na épica. Quando um texto se apresenta indefinido, quanto algum aspecto que se pretenda identificar nele - no nosso caso o modelo social que estaria representado nas cenas de assembléia da épica - é necessário criar esquemas de referências que sirvam de base, propiciando condições com as quais se possa contornar as indefinições contidas no texto. Para explicitar como essa operação ocorre no âmbito dos trabalhos sobre a sociedade homérica, iniciamos o capítulo expondo o projeto hermenêutico de Langlois e Seignobos, por meio dos quais evidencia-se os elementos empregados pela prática hermenêutica que empreende a análise dos poemas homéricos a partir de contextos externos ao texto, buscando na realidade existente fora dele as chaves que possibilitem a interpretação.

Tal caminho metodológico tem como proposta interpretar o texto a partir de informações a respeito de quem seria Homero, que época teria vivido e qual o seu papel no processo de composição da épica. Proposta hermenêutica que tem por objetivo realizar a interpretação dos poemas inserindo-os em seus contextos históricos, para assim, por meio dele, responder às questões que o próprio texto não nos propicia. Procedimento de caráter historicista, que parte do princípio de que toda obra reflete as condições sociais da época em que foi produzida.

Contrapondo-se a essa prática hermenêutica, situa-se a proposta que, negando o "paradigma do contexto externo", busca empreender a análise a partir da leitura dos próprios poemas, sem remetê-los a referências que Ihes sejam externas, 
projeto hermenêutico que denominaremos de "paradigma do contexto interno". Não se tratará aqui de escolher um dos dois procedimentos, mas de identificar o que eles possuem em comum e de percebê-los em sua dinâmica. Não descartaremos nenhum dos dois paradigmas, mas, como em um movimento de pêndulo, oscilando entre um e outro, empregaremos os dois, pois consideramos que ambos projetam luzes sobre a épica, como também criam áreas de sombras em torno dela.

No sub-item 2.2, "A fixação dos significados de dêmos e laós", a questão metodológica ainda continua em primeiro plano. Nele, aborda-se de que forma os vocábulos dêmos e laós são apropriados pela crítica de maneira a expressar conteúdos sociais específicos que se harmonizem com o conjunto da interpretação, servindo como base de referência para delimitar um contexto que aparece como indefinido. Quais seriam os conteúdos sociais que estariam encerrados nessas duas palavras, traduzidas tradicionalmente por "povo"? Responder essa pergunta significa dar conta de uma das principais questões que anima o debate sobre a organização social retratada nos poemas: a dos grupos sociais que estariam presentes nas assembléias e a da estrutura hierárquica correspondente. Seria possível resolver os problemas de interpretação, referentes à estruturação da sociedade homérica, pela fixação clara e objetiva dos significados de dêmos e laós?

Tendo, ao final desse capítulo, identificado as linhas básicas do "paradigma do contexto externo" e apresentado o paradigma de interpretação que se lhe contrapõe, a partir do "capítulo 3", "A ágora e os limites da vida civilizada", passa-se a apresentar nossa própria proposta de hermenêutica das cenas de assembléias presentes no texto homérico. Nesse capítulo, discute-se a vinculação que se faz a entre a ausência de assembléias e a constituição de modos de vida selvagem. O texto épico portaria um conceito de "selvageria" que estivesse relacionado com 
formas específicas de organização social a tal ponto de poder-se afirmar que para "Homero" os Ciclopes eram selvagens por não possuírem ágora? A assembléia teria na épica um papel definidor do que seria selvagem ou civilizado?

Para responder essa questão, iniciamos com a análise dos significados do vocábulo ágrios, selvagem, presente na pergunta, constantemente repetida por Odisseu a cada novo lugar a que chegava a suas errâncias: "As gentes que habitam essa terra serão desmedidas, selvagens e injustas, ou hospitaleiras e tementes aos deuses". Quais seriam os conteúdos sociais embutidos na palavra ágrios (selvagem)? Com essas palavras, estaria Odisseu expressando as oposições entre civilização e selvageria ou natureza e cultura; idéias que são tão caras ao pensamento contemporâneo? A idéia de selvagem estaria em Homero vinculada a práticas econômicas e sociais específicas?

No quarto capítulo, analisam-se três reuniões figuradas na ágora de Ítaca. No sub-item 4.1 , "A Assembléia de Telêmaco", aborda-se a reunião convocada por Telêmaco, na qual ele exorta os pretendentes a abandonar sua casa, focando o jogo retórico mantido entre as partes, e sua relação com o silêncio do povo, que não intervém na questão. A crítica tradicional aponta que sua inércia dever-se-ia à questão tratada nela: um assunto de natureza particular, concernente somente à Telêmaco e aos pretendentes. Nesse sentido costuma-se observar que Telêmaco sequer teria se dirigido ao povo presente na assembléia. Nessa abordagem, procura-se expor que a fronteira entre o particular e o público não é claramente delineada, pois, embora Telêmaco mesmo manifeste consciência de que sua questão era de ordem particular, ele mesmo a aborda no sentido de conferir-lhe uma dimensão coletiva, sendo o povo presente um destinatário importante de suas palavras. 
No sub-item seguinte, apresenta-se a "Reunião dos pretendentes". Aqui, diferentemente do que aconteceu na "Assembléia de Telêmaco", os pretendentes temem a reação do povo, que não está presente na reunião, mas é aludido como um perigo, caso viesse se colocar contra eles. Temos nessa reunião uma mudança na forma como os pretendentes caracterizam o povo. Qual seria a sua significação para o conjunto da narrativa?

No último sub-item desse capítulo, 4.3, analisa-se a assembléia que se reúne após a noticia da morte dos pretendentes ter espalhado pela cidade. Nela, os parentes dos mortos pedem vingança, porém os presentes na assembléia se dividem: uns vão ao encalço de Odisseu, outros debandam com medo de terem o mesmo destino dos outros. Abordaremos nessa discussão principalmente a natureza dessa divisão e quais seriam seus possíveis significados para a interpretação da sociedade que se retrata nos poemas. No último capítulo, "A cena final", apresentaremos nossas conclusões. 
2 - OlHARES E INTERPRETAÇÕES: AS QUESTÕES DE MÉTODO NA HERMENÊUTICA DAS CENAS DE ASSEMBLÉIA NA ÉPICA HOMÉRICA 


\section{1 - A crítica histórica e a questão da autoria e do processo de composição da épica homérica}

Estudar a representação do espaço comunitário, por meio de como a épica retrata as cenas de assembléia envolve, questões metodológicas que não podem ser deixadas de lado. A pergunta, que se colocou a princípio, é a de quais são as possibilidades de interpretação das formas sociais retratadas no texto homérico e de que forma a metodologia empregada na análise pode conduzir seus resultados?

A forma como Langlois e Seignobos conceberam a operação de interpretar um testemunho histórico aparece como de grande valia para a tarefa de buscar respostas para as questões acima colocadas. Não que se defenda o método deles. Nem se pretende, ao utilizá-lo, também fixá-lo como uma origem de um determinado procedimento metodológico. Traz-se essa diretriz metodológica para a análise por se considerar que o trabalho deles reflete de maneira clara e límpida importante maneira, ainda hoje, de proceder à análise dos poemas homéricos. Segundo a prática interpretativa que preconizam, quando um zoólogo descreve a forma e o comprimento de um músculo, pode-se aceitar em bloco seus resultados, pois sabese por que métodos foram obtidos. Mas quando Tácito, dizem eles, referindo-se aos germanos, escrevera "arva per annos mutant" não se sabe como ele teria procedido para informar-se nem em que sentido teria tomado as palavras "arva" e "mutant". Diante de indefinições dessa natureza, observam que a prática mais comum, entre os eruditos, é de executar a interpretação a partir do seu próprio esquema de referências (1946, p.100). Citando Coulanges, sempre ele, escrevem 
Alguns eruditos começam por formar uma opinião [...] e só depois disso é que lêem os textos. Arriscam-se, assim, e muito, a não compreenderem os textos, ou a os compreenderem falsamente. Entre o texto e o espírito prevenido, que o lê, estabelece-se uma espécie de conflito: o espírito recusa-se a aceitar o que é contrário à sua idéia, e o resultado ordinário deste conflito é que o espírito não se renda à evidência do texto, mas que este ceda, adultere-se e amolde-se à opinião pré-concebida do espírito.(Ibid., p. 102).

Por meio de Coulanges, eles apresentam a existência de um conflito presente no ato de interpretação, no qual os juízos pessoais impedem a possibilidade do entendimento correto de um texto. Não se trata aqui de discutir a possibilidade de, pelo emprego de técnicas investigativas corretas, eliminar a influência do sujeito na pesquisa, para que a interpretação possa descrever o documento "tal como ele é". A preocupação (nesse trabalho) é com os procedimentos de análise que preconizam, não com as justificativas epistemológicas que apresentam.

Adulteração, erro, falsidade são palavras constantes no fraseado de Langlois e Seignobos. Elas representam as realidades que buscam contornar por meio do método investigativo que apresentam. Citando Coulanges, observam que "a análise de um texto [...] consiste em estabelecer o sentido de cada palavra, em apreender o verdadeiro pensamento de quem escreveu...". Para eles, estabelecer o sentido literal de cada palavra seria um momento crucial da crítica de interpretação. "Estes estudos de palavras", afirmam ainda citando Coulanges, "tem uma grande importância na ciência histórica, pois um termo mal interpretado pode ser a fonte de grandes erros" (lbid., p. 107).

O estabelecimento do significado correto de cada palavra caracterizar-se-ia por uma operação de análise lingüística, dada pela prática da filologia, que, se aplicada 
com rigor, constituir-se-ia em um método exato de interpretação. Tal prática aliada à aplicação da regra do contexto, não deixaria qualquer margem para a possibilidade de erro:

\begin{abstract}
Uma expressão muda de sentido segundo a passagem em que se encontra; devemos, portanto, interpretar cada palavra e cada frase, não de modo isolado, mas tendo em consideração o sentido geral do trecho (o contexto). É a regra do contexto, a regra fundamental de interpretação. Ela nos obriga a ler o trecho todo, antes de nos utilizarmos uma de uma de suas frases; proíbe-nos, em um trabalho moderno, de amontoar citações, isto é, fragmentos de frases arrancados de uma passagem, da qual ignoramos o sentido especial dado pelo contexto (Ibid., p. 105, grifo nosso).
\end{abstract}

Na hermenêutica preconizada por Langlois e Seignobos, a fixação das idéias contidas em um documento advém da aplicação criteriosa e sistemática de um método interpretativo que busca fixar, com exatidão, o significado de cada expressão. A tal fase da interpretação, chamam de crítica positiva.

Outro momento fundamental da crítica, segundo eles, seria a aplicação da "regra da desconfiança metódica", segundo a qual o historiador deve desconfiar de qualquer afirmação, pois pode ser errônea ou mentirosa (lbid., p. 101). Tal procedimento, constitui a crítica negativa de interpretação. Nela, a validade das afirmações de um documento depende das condições em que seu autor teria operado para produzi-lo. Nesse sentido, Langlois e Seignobos prescreveram:

Devemos, portanto, começar por estudar as informações que possuímos, referentes ao autor e à composição do documento, com a preocupação de procurar nos hábitos, nos sentimentos e na situação pessoal do autor, ou nas circunstâncias da composição, todos os motivos que possam ter inclinado a proceder incorretamente 
ou, ao contrário, a proceder com correção excepcional (lbid., p. 115, grifo nosso).

Tanto na crítica de interpretação positiva como na negativa tem-se na idéia do "contexto" o eixo referencial em que articulam a prática da análise. No caso da interpretação positiva, o significado de uma palavra ou de uma oração deve ser obtido não de forma isolada, mas no contexto em que se encontra inscrito. $O$ significado da parte se desvenda pela relação que mantém com o todo. No caso da crítica negativa, a aplicação da "regra do contexto" abrange os aspectos da forma como o documento foi produzido e da vida de seu autor. Considera-se assim que são três os elementos básicos que compõem o instrumental metodológico de que se servem: a crítica filológica, a compreensão do processo de produção do documento e os aspectos da vida de seu autor. Tudo isso orquestrado pela aplicação da regra do contexto.

O método presente em Langlois e Seignobos subjaz como pressuposto epistemológico das exegeses textuais de parte importante dos que se dedicam a critica histórica dos poemas. Ao analisar as cenas de assembléia, os praticantes desse paradigma buscam fixar significados precisos para os vocábulos que compõem o episódio, principalmente para os que se destinam a identificar os grupos sociais que estariam figurados na reunião. Entre esses vocábulos encontra-se, como caso mais notório, os significados que são atribuídos às palavras dêmos e laós. O outro passo consiste em identificar o processo de composição dos poemas, por meio da compreensão das formas de composição da poesia narrativa oral e da questão da autoria, buscando determinar quem seria Homero, quando e onde teria vivido. 
O trabalho de Finley é modelar nesse sentido. Articulando com clareza as três operações citadas acima e não se esquivando dos problemas metodológicos implicados por suas opções, apresenta, em seu "Mundo de Ulisses," os principais pontos em torno dos quais orbitam o debate sobre as assembléias homéricas. Sua influência na formulação das questões que envolvem os estudos sobre as práticas comunitárias na épica homérica é inconteste. Raro o trabalho produzido sobre o assunto que não faça referência a ele, seja para concordar, seja para discordar de suas formulações. Suas respostas talvez possam não satisfazer, porém, nele encontramos um fio condutor, o nosso fio de Ariadne, com o qual percorreremos os caminhos desse labirinto constituído pelos debates a respeito das assembléias homéricas.

Para esta reflexão, a riqueza de seu trabalho encontra-se na clareza com que manifesta um dos principais problemas com que se lida neste trabalho: as possibilidades de interpretação da sociedade homérica e a utilização da llíada e da Odisséia como fontes históricas. Sua opinião de que o quadro social apresentado em Homero seja essencialmente coerente, apesar dos anacronismos, erros e exageros motivados pela técnica de composição da poesia oral, chama a atenção (1965, p.45), pois parece que a idéia da coerência - ou incoerência - do relato homérico conduz, de uma forma ou de outra, as discussões a respeito do tema, uma vez que, mesmo que não seja de forma explícita, o conceito acaba tornando-se critério validador da interpretação histórica dos modelos sociais figurados na épica.

Não interessa aqui tanto o mérito das conclusões de Finley quanto à forma como articula seus termos. A preocupação é metodológica. A intenção não é avaliar se sua descrição do mundo de Odisseu seja verdadeira ou falsa, mas averiguar como argumenta e as referências a partir das quais constrói seu raciocínio. A 
atenção é dada ao que ele mesmo propôs e aconselhou em "Generalizações em história antiga", ensaio em que destaca os modos pelos quais os historiadores da Antigüidade empreendem seu trabalho. Nele observa que, em seu ofício, os historiadores realizam uma série de operações, na maior parte das vezes não discutidas, que exercem funções explicativas importantes. Trata-se, segundo ele, das generalizações, o nome que dá às suposições e aos juízos utilizados pelo historiador.

Infelizmente, o historiador, [ele nos diz], não é um mero cronista, e de modo algum pode fazer o seu trabalho sem suposições e juízos, sem generalizações, em outras palavras. Na medida em que não está disposto a discutir explicitamente as generalizações - o que significa que não está disposto a refletir sobre elas -, ele corre sérios riscos.(1989, p.58).

Segundo ele, algumas generalizações seriam os resultados do trabalho de pesquisa e reflexão, sendo assim frutos das opiniões do historiador, apresentados na forma de propostas, hipóteses ou leis gerais. Outras, as mais importantes de serem discutidas, seriam as generalizações iniciais pressupostas nas tentativas de explicação histórica.

Veja-se como isso se dá em seu próprio trabalho: quais seriam os juízos e suposições, ou seja, as generalizações que fundamentariam sua afirmação de que o quadro social na épica homérica caracterizar-se-ia por anacronismos, erros e exageros motivados pelo processo de composição oral? Como considera ser possível, apesar desse cenário confuso, visualizar uma sociedade retratada de forma essencialmente coerente. Como articula, em sua explicação, a incoerência do legado poético com a coerência obtida pelo esforço de interpretação? 
Finley observa que a épica homérica apresenta distorções e que a causa encontrar-se-ia na técnica de composição da poesia oral. Segundo ele, Homero teria composto sua obra servindo-se de uma massa de mitos sobre deuses e heróis e de um tesouro em fórmulas apropriadas, criadas desde a época micênica por gerações de aedos para descrever as mais diversas situações. Essa herança poética seria composta por fórmulas que teriam surgido e se fixado em períodos diferentes. Cada uma delas apresentaria conteúdos que refletiriam as estruturas sociais dos momentos em que foram compostas (Ibid., p. 43). Homero e sua tradição de aedos não manifestariam "o mínimo interesse pela história, no sentido em que hoje a entendemos" (Ibid., p.26). "Ora deliberadas [...] ora por negligência e indiferença para com a exatidão histórica, para já não falar dos erros inevitáveis devido à transmissão oral", a intervenção de gerações de aedos teria atuado no sentido de promover sucessivas modificações na massa de fórmulas tradicionais, gerando um material cheio de erros, anacronismos e exageros (lbid., p.43). Assim, o legado formular, preservado por Homero, não se caracterizaria pela coerência e rigor, que se esperaria atualmente de uma narrativa historiográfica.

Porém, para além de toda essa aparente confusão, Finley considera possível, com um tratamento adequado dado pela análise histórica, perceber um quadro geral traçado de forma precisa e coerente.

O quadro que os poemas descrevem é, no essencial, coerente. Transparecem por aqui e por ali fragmentos anacrônicos, alguns muito antigos, outros, especialmente na Odisséia, muito modernos que são reflexos da própria época do poeta. A análise histórica pode separar do quadro geral, traçado com precisão, os episódios e os pormenores da narrativa, a acção, cuja inexatidão pode ser demonstrada. (Ibid., 45, grifo nosso) 
Classificando os episódios, temas e fórmulas de acordo com o período em que teriam se fixado e corrigindo seus erros e exageros, a análise histórica desfaz o que ele chama de confusão homérica. Desse modo, a visão de um quadro de fundo, traçado de forma precisa e coerente, é obtida pela separação, atenuação e cortes de elementos que aparecem misturados nos poemas. Os perigos desse procedimento analítico, ele mesmo aponta

somos tentados a não ter em conta tudo o que a escolha deliberada feita pelo poeta implica, a afastar as conclusões e contradições aparentes das questões sociais e políticas (enquanto distintas, dos incidentes da narrativa), como se se tratasse simplesmente da negligência de um bardo que não se preocupava com a realidade histórica.(Ibid., p.46)

Erros, inexatidões, exageros e contradições de um lado; um mundo real, traçado de forma precisa e coerente de outro. Parece que seu sistema considera a contradição como erro, o que pode induzir a um resultado, como ele diz, que afaste das conclusões as contradições aparentes das questões sociais. Porém, ele mesmo neutraliza essa possibilidade, confirmando a eficácia de seu procedimento, ao afirmar que a margem de erro pode ser reduzida a um mínimo aceitável, pois seu trabalho repousaria em uma análise global dos poemas e não em um simples verso, passagem ou episódio; e a história grega posterior e o estudo de outras sociedades, ofereceriam um largo meio de controle.

Finley utiliza o conceito de coerência como critério validador da historicidade de seu modelo de sociedade homérica. Parece mesmo considerar que o próprio Homero, conscientemente, busca essa coerência, evitando qualquer contradição em seu relato (Ibid., p. 93). Homero teria composto sua épica com um mínimo de 
interferência pessoal, transmitindo o legado formular herdado "com precisão na aparência gelada" (Ibid., p. 46). A maior parte desse legado poético ter-se-ia se fixado durante os séculos X e IX, expressando, assim, os valores e a organização social dessa época. Desse modo, Homero constituir-se-ia muito mais em um retransmissor da visão de mundo de seus antepassados do que um espelho de sua própria época (p. 46). A llíada e a Odisséia serviriam de focos de luz sobre o passado que antecedeu a experiência da organização da pólis arcaica durante os séculos VIII e VII. Dessa forma, a sociedade homérica seria pré-política. Nela ainda faltaria o princípio da cidadania e o pleno desenvolvimento da idéia de comunidade política que, em Homero, ainda seria embrionário. Esse é o ponto de referência em torno do qual Finley constrói o seu quadro geral. Sob o título de anacronismos, erros e exageros, tudo que lhe parecer micênico ou político estará fora dele.

O seu trabalho de separação dos fragmentos micênicos e arcaicos do quadro geral, composto pelo mundo dos séculos X e IX, é facilitado pelo pressuposto de que o próprio Homero possuiria consciência das misturas que promovia em seu relato, principalmente no que respeita ao que seria de sua própria criação, e ao que pertenceria ao legado herdado. Finley em nenhum momento afirma isso, mas trabalha como se fosse assim. Em um comentário sobre a vinculação entre o governo justo de um rei e os benefícios que isso proporciona ao seu povo, conclui que tal noção é anacrônica, pois pertenceria aos séculos VIII e VII e não ao mundo de Ulisses. A inclusão desse conceito, na Odisséia, seria motivada pela liberdade de Homero em introduzir no seu relato uma noção contemporânea sua. Porém, Finley afirma (lbid., p.93): "fá-lo com toda cautela, a propósito de uma comparação inocente, evitando, por esse meio, toda contradição na própria narrativa". 
Diferentemente de Langlois e Seignobos, Finley assume que juízos, valores e suposições são elementos inerentes ao ato da interpretação. As generalizações, como ele as chama, fazem parte do trabalho do historiador, que não pode e não deve evitá-las, mas assumi-las como elementos constituintes de seu trabalho. Porém, se discorda de Langlois e Seignobos, quanto ao papel dos juízos, não descarta os procedimentos analíticos preconizados por eles, pois sua análise articula-se em torno dos mesmos eixos. Localizando Homero no tempo, estabelece dados a respeito da vida do autor. Ao descrever a maneira como os poemas teriam sido compostos, determina o modo como o documento, no caso aqui a llíada e a Odisséia, vieram a tomar existência. Fixando os significados dos vocábulos gregos que aludem à organização de grupos e relações comunitárias, busca determinar o significado preciso de cada palavra do texto. A vida do autor, o processo de composição do documento e a fixação precisa dos significados dos vocábulos contidos no documento, elementos constitutivos da análise de Langlois e Seignobos, estão todos aqui, embora Finley os articule de maneira diferente. Por meio deles, realiza sua "analise histórica", não se fixando na idéia de verdadeiro ou falso, como fazem Langlois e Seignobos, mas na de coerência ou incoerência do relato ${ }^{17}$.

Morris de maneira explícita, sem deixar qualquer margem de dúvidas, expressa claramente o postulado metodológico da crítica positivista de Langlois e Seignobos. No âmbito dos estudos homéricos, ele nos diz, os historiadores têm concentrado

\footnotetext{
${ }^{17}$ Adkins (1971) concorda com a estrutura geral montada por Finley e reforça a idéia da coerência como validador de uma contrapartida histórica para a sociedade que se apresenta nos poemas. Considera impossível acreditar que os bardos da tradição oral tivessem inventado de sua própria imaginação uma sociedade com instituições, valores, crenças e atitudes tão coerentes e mutuamente apropriadas. Segundo ele, tal adequação somente poderia estar baseada na vivência social.
} 
atenção nas instituições encontradas nos poemas e na questão de que estágio de desenvolvimento elas se encontraria. Os problemas postos para tal análise partiriam de três características dos poemas: 1) os poemas seriam o resultado do processo de composição oral; 2) os poemas teriam adquirido a forma com a qual chegaram até nós, no curso do século VIII; e 3) os eventos, sobre os quais se baseariam seriam do século XII. Como o processo de composição dos poemas teria perdurado, segundo ele, por todo o período que se estende do século XII ao VII, tornou-se possível aos historiadores ver, na llíada e na Odisséia, a representação de uma sociedade que teria existido em qualquer ponto desse período, ou uma mistura de várias épocas. Assim, segundo Morris, a chave para uma boa compreensão dos poemas encontrar-se-ia no processo de composição dos mesmos, ou seja, "como", "quando", "por que" e "por quem" eles teriam sido criados. É por meio das respostas que fornece para essas indagações que ele empreende sua análise, fixando Homero no tempo e contextualizando a épica em seu ambiente histórico-social. A questão da autoria e do processo de composição, elementos constituintes da critica positivista de Langlois e Seignobos, encontram-se assim expressos como fatores preponderantes da hermenêutica de Morris. Porém, pautando-se em Lord, advoga que, diferentemente de Finley, a épica homérica guardaria fortes relações com o contexto social do século VIII, pois, na composição oral, em virtude de o poeta compor durante a perfomance e não simplesmente recitar versos memorizados, sempre iguais, cada performance de um canto seria diferente da outra. Desse modo, um poema dificilmente restaria estático durante longo tempo. As sociedades não letradas flutuariam em um constante presente. Idéias que não fossem muito relevantes tenderiam a desaparecer, fazendo com que apenas os elementos que possuíssem sentido para a platéia e o cantor fossem preservados pelo canto. A 
épica, portanto, teria relação com a sociedade vivida pelo poeta, embora não fosse um reflexo direto dela, pois, além dos efeitos da "distância épica", também seria modelada pelo ponto de vista do poeta, que exagera alguns elementos e diminui a importância de outros ${ }^{18}$.

Segundo Morris, o argumento mais sério de Finley para sustentar que a sociedade homérica retrataria o mundo grego dos séculos $X$ e IX seria sua observação de que neles não encontraríamos a instituição da pólis, porém, de acordo com Morris, Finley não diz o que esperava encontrar em Homero para aceitar o século VIII como base dos poemas. Afirma apenas que a organização social do mundo de Odisseu era inadequada para as incumbências conhecidas de algumas pólis contemporâneas de Homero. A isso, Morris observa que a distinção entre público e privado era bem compreendida e o poder da assembléia era considerável e que ela seria capaz de organizar as mesmas atividades que as cidades gregas do século VIII assumiam ${ }^{19}$. Assim, conclui que a afirmação de Finley de que o mundo de Odisseu era fundamentado estritamente no oikos seria infundada, pois a comunidade decidia as questões que ameaçavam o seu equilíbrio.

Embora discordem quanto à época histórica que os poemas refletiriam, ambos, relacionando os poemas a um determinado período histórico, executam os mesmos

\footnotetext{
${ }^{18}$ Morris observa que o poeta descrevia eventos ocorridos em um passado que todos sabiam ser diferentes da época presente. Para recriar esse efeito utilizava-se a ferramenta narrativa da "distância épica". Essas podem ser de natureza puramente inventiva como riquezas e forças exageradas, monstros ou rios falantes, ou de natureza arcaizantes como elmos com dentes de javali, armas de bronze e carros de guerra, que apesar de serem instrumentos não mais utilizados no século VIII, ainda se possuía referência deles na época do poeta.

${ }^{19}$ Morris cita a passagem Odisséia 2.32, 44-45 como exemplo da distinção entre público e privado, e a passagem Odisséia 2.192-3 como exemplo do poder da assembléia.
} 
passos. O princípio básico do procedimento que adotam é apontado de forma límpida e concisa por Trabulsi, que também o emprega. Diante da dificuldade de se trabalhar com uma fonte histórica da natureza da llíada e da Odisséia, ele propõe a necessidade de se partir de uma base segura, que ele chama de regra de ouro do método histórico: "proponho que partamos de uma base segura, de uma das regras de ouro do método histórico: uma fonte, qualquer que seja, deve ser inicialmente recolocada em seu contexto de produção." (2001, p. 22, grifo nosso).

Seguindo sua proposta metodológica, situa a época em que a llíada e a Odisséia teriam sido compostas, datando-as entre os séculos VIII e VII, período do surgimento da Cidade-Estado. Então, como para ele a criação poética oral reflete a sociedade em que ela se processa e não o mundo que pretende descrever, Homero em seus poemas estaria refletindo basicamente a realidade de sua própria experiência histórica: a realidade histórica da pólis.

Homero revela um quadro do século VIII, plenamente políade em certos aspectos, protopolíade em outros.(Ibid., p. 44, grifo nosso)

Morris, Trabulsi e Finley executam o mesmo procedimento. Em suas análises, apoiando-se em uma interpretação de como Homero haveria processado a composição dos poemas, eles inserem o texto em seu contexto de produção, estabelecendo, por esse modo, as bases de sustentação dos esquemas de referencias que lhes permitem alinhavar os elementos encontrados na narrativa homérica de forma coerente e racional: o mundo da pólis, no caso dos dois primeiros, no caso de Finley, a "Dark Age". Morris enfatizando o papel organizativo da assembléia, Finley o do oîkos. 
Snodgrass (1974, p.114-125) duvida da possibilidade da épica homérica retratar uma sociedade realmente existente. Identificando incoerências no texto homérico, concluiu contra a existência de uma sociedade histórica na épica; entendendo por histórico um conjunto de práticas sociais pertencentes a um único período. Para ele, a sociedade descrita por Homero seria uma mistura, uma composição derivada de diversos períodos. Segundo ele, nenhuma sociedade histórica teria mostrado a combinação no uso de metais que se apresenta na épica. Nenhum grego teria testemunhado a seqüência precisa dos eventos narrados no funeral de Pátroclo e o equipamento de luta apresentaria inconsistências misturando armamentos de diversos momentos históricos.

Partindo da constatação de que Homero apresentaria uma mistura de práticas históricas, pergunta se seria possível às instituições sociais operarem independentemente da cultura material no mundo literário, respondendo que é improvável que isso tivesse ocorrido em Homero. Para ele, o mundo social retratado na épica também seria um amálgama não histórico. Ao abordar as práticas de dotes no casamento como exemplo dessa mistura, utiliza estudos antropológicos de sociedades modernas para concluir que, sob o ponto de vista da transmissão da propriedade, Homero apresenta características de duas formas diferentes de sociedades opostas, que não costumam coexistir em um mesmo modelo social, sendo assim, difícil acreditar que a sociedade homérica seja unitária e histórica.

Snodgrass, como Finley e Morris, também utiliza uma interpretação sobre a forma de composição dos poemas e do papel de Homero para confirmar e legitimar suas opiniões. Ele observa que há dois comportamentos diferentes que se inscrevem dentro da prática da poesia tradicional oral. Um deles é o poeta tradicional que tem por prática adotar de seus predecessores o conjunto das formas sociais que 
esses utilizavam. Nessa prática, o escopo por contribuições criativas seria fortemente inibido. Os poetas procurariam fazer seus personagens se comportarem exatamente do modo que estivesse fixado pela tradição. E, caso sentissem a necessidade de operar modificações, fariam de forma a apagar o máximo possível a sua interferência pessoal. Seria essa a razão para o nome dos autores das narrativas épicas dos Nibelungos, o Ciclo de Ulster, das sagas islandesas e outras do ciclo épico grego não terem sobrevivido. Snodgrass denomina os poetas praticantes dessa forma de composição de "derivativos".

O outro comportamento, embora também de caráter tradicional, não se vincularia à herança legada de um único período histórico, mas de vários. Um poeta assim seria muito mais livre para utilizar sua criatividade, selecionando e misturando contextos. O fato do nome de Homero ter sobrevivido como autor dos dois épicos seria uma forte sugestão para incluí-lo nessa tradição de poetas orais, e mais um forte argumento para sustentar a não existência de uma sociedade histórica em Homero.

Enquanto para Finley, Homero transmite o legado de fórmulas tradicionais, fixados em torno dos séculos $X$ e IX, com uma precisão na aparência gelada, e, quando julga necessário introduzir algum aspecto contemporâneo seu à narrativa, o faz de forma clara, o que permite separá-los do quadro geral, por meio da análise histórica; para Snodgrass, Homero não possui a preocupação em preservar a coerência de um quadro geral. Ele, diferentemente de um poeta tradicional derivativo, usaria sua criatividade para misturar contextos de maneira tão ampla e livre que não mais seria possível identificar nenhuma sociedade realmente existente na épica. Tanto para a cultura material como para as práticas sociais, Snodgrass argumenta que a sociedade homérica apresenta padrões que não se apresentam 
nas sociedades históricas conhecidas, concluindo, desse modo, que ela seria um amálgama não histórico.

Porém Finley e Morris não negam esse aspecto dos poemas. Para eles, o texto homérico também se caracteriza pela mistura de elementos aparentemente contraditórios. A diferença significativa entre eles reside, portanto, na natureza desse amálgama e na possibilidade de evidências externas aos poemas possibilitarem a separação de seus elementos, chegando assim, pela análise, à identificação de formas sociais coerentes e racionais. Segundo Snodgrass, o conhecimento que a arqueologia proporciona não habilita criar um esquema de referências que permita datar e classificar as relações e as práticas sociais contidas nos poemas, ou, como no caso da cultura material, alerta para a completa mistura de seus elementos; diferentemente de Finley, Morris e Trabulsi, que fixam de forma segura as referências externas sobre as quais apóiam suas análises.

A operação de relacionar a épica homérica a um contexto histórico específico é delicada. A llíada e a Odisséia são manifestações escritas únicas de seus momentos que chegaram até nós, não sendo possível cotejá-las com outras que lhes sejam paralelas, e, assim, por meio do cruzamento dos diversos testemunhos, produzir uma reconstrução histórica que não se caracterize pelo mero desdobramento da leitura que se faz dos poemas. A sociedade homérica é a que se apresenta nos poemas. Devido à ausência de evidências externas independentes, Long (1970) sustenta que não é adequado interpretar a épica como se refletisse alguma sociedade autônoma existente fora dos poemas. Para ele, inferências sobre o mundo social presente na épica não podem assumir o papel de axiomas históricos a expressar valores de uma sociedade realmente existente. 
Long também considera que as limitações determinadas pela ausência de referencias externas também devem ser observadas na própria interpretação. Elas desautorizariam sustentar argumentos que fundamentassem sua validade pela corroboração de contextos sociais externos ao próprio texto. Assim, nos diz ele, a interpretação dos poemas deve se assentar em suas próprias lógicas internas. Porém, ao não recorrer a evidências externas que lhe propicie esquemas de referências, permitindo a análise dos poemas a partir de um eixo orientador que lhe sirva de modelo, não tem como operar e solucionar os problemas que se apresentam à interpretação em termos de um quadro coerentemente construído. A respeito das estruturas sociais que se apresentariam nos poemas, observa que deles não emerge um modelo consistente de sociedade. Em um de seus exemplos, aborda diretamente a questão aqui proposta, colocando lado a lado o oîkos e a assembléia, sem que um oblitere o outro, como fizeram Finley e Morris. Segundo ele, se o povo de Ítaca passou vinte anos sem reunir a assembléia, o que diminuiria a importância da organização comunitária em favor da autonomia do oîkos, como observam Finley e Adkins, no episódio do escudo de Aquiles retrata-se uma assembléia na qual o povo reunido presencia uma disputa a respeito de um assassinato.

Long e Snodgrass têm em comum o procedimento de não separar os elementos amalgamados em Homero, por meio de referências externas aos poemas. Porém, se se distanciam de Finley-Morris por considerarem que a sociedade homérica se apresenta incoerente, na questão metodológica, eles se aproximam, pois a condução da análise em termos de incoerência ou inconsistência também exige a fixação de um esquema de referências que permita o trabalho de seleção, catalogação e, principalmente, a elaboração de juízos a respeito da 
coerência ou não das realidades detectadas. Qual seria esse esquema de referência?

Para avaliar o papel da assembléia na épica homérica, Finley, Morris e Long, embora cheguem a conclusões distintas, têm como referência o processo de constituição da Cidade-estado. Nesse sentido, ao fixarem o papel das assembléias na sociedade homérica, acabam por realizar uma operação que busca identificar em que ponto do processo de constituição da pólis encontrar-se-ia a sociedade retratada nos poemas. Ela se identificaria mais com uma organização comunitária frágil assentada na esfera da casa patriarcal (oîkos), ou já apresentaria fortes elementos comunitários expressos pela importância das assembléias como espaço organizador da coletividade?

Nessa operação busca-se identificar a sociedade homérica com um período histórico específico: o Micênico, a "Dark Age" e os princípios do arcaico. Para cada um deles, a relação "realeza x oîkos x assembléia" teria uma característica diferente, com o predomínio de um deles sobre os demais: para o Micênico, o predomínio da realeza; a "Dark Age", o oîkos; o arcaico, o aumento da importância da assembléia. Assim para Finley, que identifica a "Dark Age" como fundo histórico dos poemas, a organização social representada nos poemas assenta-se no oîkos aristocrático. Para Morris, que os relaciona ao século VIII, a assembléia expressa já um forte elemento comunitário, sinalizando as estruturas da cidade-estado nascente. Para Long, que não os relaciona a período algum, a sociedade homérica apresenta-se como inconsistente, justapondo a estrutura do oîkos e da assembléia, não optando assim por nenhum cenário para selecionar uma dessas duas instâncias de organização como elemento definidor do mundo homérico. 
A atribuição de uma referência histórica externa específica apresenta-se associada à fixação de uma interpretação de como se haveria processado a composição dos poemas. Assim, tem-se em Finley, que Homero os teria compostos a partir de fórmula fixadas pela tradição, remontando aos séculos X e IX. Em Morris, que a composição oral flutua em um eterno presente, devendo, portanto, retratar a organização social vivenciada por Homero. Snodgrass, por sua vez, considera que Homero seria um poeta que conscientemente misturava contextos criando na épica um mundo que não possuiria contrapartida histórica real.

\begin{tabular}{|l|l|l|}
\hline Finley & séculos XI e X & $\begin{array}{l}\text { Homero retransmite basicamente versos } \\
\text { fixados pela tradição. }\end{array}$ \\
\hline Morris & $\begin{array}{l}\text { século VIII } \\
\text { Homero recria basicamente o mundo de sua } \\
\text { própria experiência histórica. }\end{array}$ \\
\hline Snodgrass & $\begin{array}{l}\text { Homero mistura completamente os } \\
\text { contextos históricos. } \\
\text { a soméricada é uma } \\
\text { ficção }\end{array}$ &
\end{tabular}

A importância da fixação de um modelo de como foi operada a composição dos poemas e de quem seria Homero é um dos passos fundamentais na interpretação das cenas de assembléia na épica. Viu-se que Long considera que a ausência de evidências externas impede que possa atribuir as características apresentadas nos poemas a algum período histórico específico. Porém, a questão, como ele apresenta de forma exemplar, tem dois lados. Não se trataria somente do procedimento de, a partir das informações contidas nos poemas, buscar um período histórico ao qual elas corresponderiam, mas da operação inversa: o de a partir de um contexto externo específico, operar a interpretação dos poemas, ou seja, resolver os 
problemas de interpretação do texto a partir do contexto externo. O de fazer, dessa operação, a chave de sua interpretação.

Solucionar os problemas de interpretação das cenas de assembléias a partir da fixação de evidências externas ao texto é uma prática largamente utilizada nos estudos homéricos. Mas tal solução metodológica não encerraria exatamente seu principal problema: o de se identificar qual tipo de sociedade estaria representada nos poemas homéricos? Agindo assim a discussão não se estaria deslocando do texto em si para as questões que envolvem a vida do autor e o processo de composição de sua obra?

Mas quem seria Homero? Teria ele realmente existido? Como teria se processado a composição dos dois poemas? Situá-los em seus contextos de produção não envolveria o conhecimento de realidades que tem nos próprios poemas seus principais testemunhos? Assim se o texto se apresenta indefinido, quanto às questões de ordem social que retrata, seria o conhecimento da vida de Homero e de como ele teria operado para compor a obra bases referencias seguras para a interpretação? A questão não se resume somente em considerá-la histórica ou não, mas da própria possibilidade de interpretação das formas sociais contidas na épica, nos termos do processo de constituição 


\section{1 - A crítica histórica e a fixação dos significados de dêmos e laós}

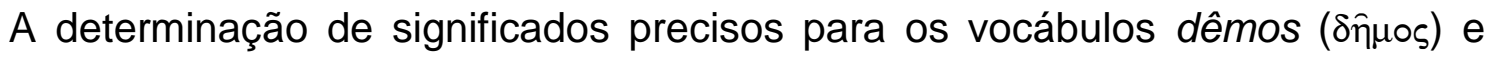

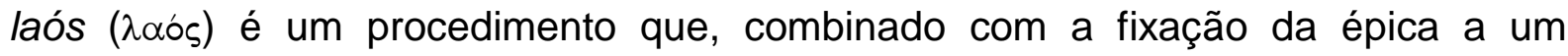
contexto histórico específico, possui papel importante no esforço de interpretação das formas sociais representadas nos poemas. Finley (1989) adverte para os perigos dessa prática. Toda tradução, diz ele, implica a atribuição de significados que não devem ser passadas como naturais, no sentido de se considerar que, entre o vocábulo traduzido e o que foi utilizado para expressar seu significado, houvesse uma relação direta de equivalência. Segundo ele, os termos e os conceitos utilizados por todo historiador para traduzir vocábulos antigos raramente são empregados de modo neutro, e seus usos pressupõem proposições gerais que acabam cumprindo função explicativa infundada. Ele aponta, como exemplo, o caso da palavra "escravo", originada na Idade Média, que a princípio designava os cativos da guerra eslava na Europa oriental. Tal palavra, diz, somente poderia ser transferida para a Antigüidade de um modo anacrônico, pois, contemporaneamente, ela suscita associações que remetem a relações sociais distintas daquelas que caracterizariam a "escravidão antiga". Para Finley, a tentativa de solucionar esse problema pela adoção do termo grego transliterado seria um equívoco, além de uma omissão diante das dificuldades no trabalho de compreensão das sociedades antigas, já que, segundo ele, todas as palavras ensejariam associações. Assim, doûlos, como palavra isolada, poderia não ter sentido algum para o historiador moderno, 
dificultando, desse modo, associações com realidades contemporâneas. Mas, uma vez que estivesse diante da formulação 'doûloi' em Atenas, ele sendo humano, inevitavelmente a associaria à servidão e daí a escravidão. Assim, conclui, o procedimento de transliterar o vocábulo grego não impediria as associações com os conceitos modernos, além de produzir formulações e raciocínios vagos, não primados pelo uso preciso dos conceitos.

Traduzir ou transliterar, como deveríamos proceder com os vocábulos dêmos e laós? A questão colocada por Finley deve ser apreciada de frente. As duas opções contêm seus inconvenientes. Qualquer que seja a escolha sempre restará a sensação de que melhor teria sido optar pela outra. Porém mais importante do que decidir entre elas, parece a advertência feita por ele: a tradução de vocábulos que identificam formas de relações sociais passa pela própria interpretação dessas relações. Concordamos com Finley. Traduzir significa interpretar, mesmo que se trate do significado de uma única palavra, e o historiador não deve furtar-se desse papel. Porém, se as relações sociais, às quais um determinado vocábulo se refere, se apresentam de forma indefinida como poderíamos precisar seus significados? Nesses casos, se a transliteração pode produzir interpretações vagas, a opção pela tradução pode levar ao efeito contrário: o de , pela fixação de significados precisos, produzir interpretações que eliminem as indefinições e contradições apresentadas pelo contexto em que estão inseridas, dotando o texto com um caráter preciso e coerentemente racional. Deve-se tomar cuidado com essa questão, para que se peque por empregar definições rígidas, que engessem nossa argumentação, nem por demais fluídas, a ponto de perderem toda força explicativa.

Segundo Benveniste (1995, p.91), em Homero, laós, junto com dêmos seriam os dois principais vocábulos que expressariam a idéia de povo. Ambos teriam seus 
significados ligados à idéia de coletivo-público. Laós seria de origem aquéia,

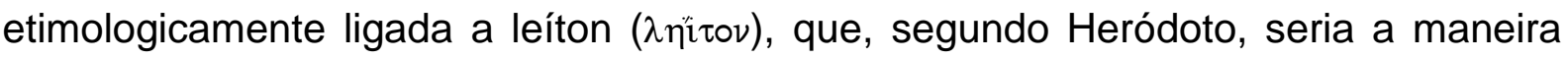
como os aqueus denominavam o prytanêion ( $\pi \rho v \tau \alpha \nu$ îiov). Leíton comporia uma série de palavras cujos significados estariam associados às funções públicas como, por exemplo, leitourgía ( $\lambda \varepsilon \imath \tau o v p \gamma i \alpha)$. Por sua vez, no domínio dórico, a noção

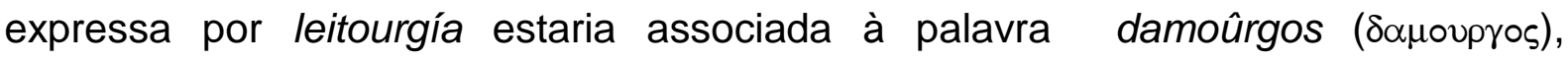

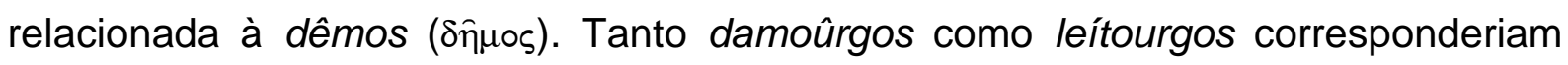
em sentido, sendo a primeira uma forma dórica e a outra, aquéia-eólica. Porém, embora Benveniste apresente uma etimologia ligando dêmos e laós à idéia de coletivo-público, relacionando-as ao contexto micênico e dórico, ele identifica, em Homero, uma diferença de nuance de sentido entre ambas. Laós seria uma organização própria das antigas sociedades guerreiras, que se constataria entre os germanos: a comunidade guerreira, o nome do povo enquanto porta armas, não abrangendo velhos e crianças. dêmos, por sua vez, abarcaria um conceito territorial e político, designando, ao mesmo tempo uma porção de território e o povo que nele habita.

Donlan (1980, p.225-36) observa que dêmos denominaria tanto a terra pertencente a comunidade como o povo que nela habita. Seria a vila no seu sentido humano e geográfico. Por vezes, dêmos seria mesmo empregado sem que fosse possível discernir, pelo contexto, em qual dos dois sentidos ele esteja sendo empregado. Segundo ele, essa confusão demonstraria uma estreita conexão entre os dois conceitos: a terra e o povo que nela habita seriam um.

Para Scheid-Tissienier (2002, p.10) o termo laós, utilizado no singular ou no plural, remeteria sempre a um grupo ou a uma coletividade, no seio da qual as 
pessoas jamais seriam individualizadas. Os próprios adjetivos que qualificariam essa massa de homens insistiriam sempre sobre o número elevado de elementos que o compõe. O laós, ela nos diz, é antes a tropa de guerreiros que segue o seu chefe. dêmos, por sua vez, designaria uma coletividade territorial e a comunidade ao qual todos os homens pertenceriam (Ibid., p.18). No seio dessa comunidade, distinguirse-ia o rei e, muitas vezes, os nobres.

As definições mostradas acima são abrangentes e praticamente consensuais. dêmos denotaria a comunidade tanto nos seu aspecto humano, como territorial. $\mathrm{O}$ laós, o bando guerreiro constituído pelos homens da comunidade. Mas essa não é a única maneira de se enquadrar a questão. As definições apresentadas até aqui possuem um caráter inclusivo, referindo-se ao conjunto do agrupamento de forma indistinta, elas expressam a idéia do todo. Porém, as análises produzidas sobre as cenas de assembléias tendem a deslocar os seus sentidos, conferindo-lhes significados que não mais expressem a idéia do todo, mas de apenas uma parte do tecido social. De conceitos inclusivos que denotariam o conjunto da sociedade de forma indistinta, passam a ter um caráter exclusivo, identificando apenas um grupo no seio da comunidade.

Em Glotz, encontramos uma dos principais exemplos desse procedimento. Sua interpretação sobre o papel do povo nas assembléias homéricas ainda hoje compõe o que poderíamos chamar de um de seus modelos explicativos dominantes, o que não quer dizer que o consideremos uma origem, um ponto inicial a partir do qual se teria irradiado influências que ainda marcariam as análises sobre a sociedade homérica. Pensamos essas afinidades em termos de comunhão de perspectiva, sem nos preocuparmos com suas vias de transmissão, nem sua origem. Utilizamos Glotz 
pois, em seu trabalho, encontramos expressa, de maneira clara e concisa, uma prática analítica que consideramos paradigmática.

Glotz insere a assembléia no contexto geral das instâncias organizativas da sociedade homérica. A organização política que a conformaria seria a de uma monarquia patriarcal em que o rei assume funções de chefe militar, religioso e político. O rei, embora pareça ser muito poderoso, não governa sozinho, pois é circundado por um conselho, formado de nobres provenientes das famílias mais poderosas da cidade. Seus poderes, diz ele, seriam nulos sem o apoio do seu grupo de conselheiros, embora as decisões fossem sempre, em última instância, uma prerrogativa real, já que o conselho seria apenas consultivo, mesmo que fosse temerário não respeitar sua opinião.

Depois de haver consultado os gerontes, o rei precisa anunciar ao povo as resoluções que tomou, e informá-lo dos seus planos, pois, além da opinião dos nobres, havia também a do "dêmos" , a da arraia-miúda, da ralé. Para tanto, ele convocava a agorá, "a assembléia plena", em que se reuniam todos os laói - "todos os cidadãos que compunham a urbe" - a massa daqueles que não tinham assento no conselho.

O relato de Glotz é certeiro, resultado de um texto objetivo que não executa contornos para percorrer ambigüidades e indefinições. Sua sociedade homérica é bipartida. De um lado temos os grandes, aqueles que ocupam lugar no conselho, de outro, a arraia-miúda, os pequenos, identificados, por ele, aos vocábulos "dêmos", "laói" e "plêthos". Eles se reúnem na assembléia, um espaço organizativo fundamental da cidade, porém ainda sem as funções deliberativas que a caracterizaram durante o período clássico. Em Homero, ela seria apenas o local em 
que o rei comunicava ao "povo" as suas decisões, ou testava os seus humores. A assembléia homérica, nos diz Glotz, é um lugar

\begin{abstract}
onde se delibera sobre os meios de remediar as calamidades públicas, tais como a peste ou discórdia entre os chefes; nela se discute que recompensas devem ser adjudicadas a serviços prestados à coisa pública; nela se apresentam os estrangeiros em trânsito, a quem cumpre repatriar; nela se anunciam as notícias chegadas do exército em campanha; nela se propõe a abertura de negociações de paz. Na ágora do exército, debate-se a libertação de prisioneiros e cativos, indaga-se da conveniência de prosseguir a guerra ou bater em retirada, examina-se as propostas trazidas pelo inimigo (1988, p.45).
\end{abstract}

Para ele, todas essas funções poderiam levar a que acreditássemos no poder político do dêmos, do povo, da raia miúda da sociedade, e da importância da assembléia como espaço deliberativo. Porém, observa que não é assim que se passa, pois o papel do povo, nessas assembléias, limitava-se à assistência próxima do mutismo e da inércia.

O modelo explicativo de Finley não se distancia muito do de Glotz. Seu "mundo de Ulisses" também é caracterizado por uma profunda clivagem social. Acima da linha divisória, estariam os áristoi, detentores da maior parte da riqueza e de todo poder. Abaixo, todos os outros, aos quais, segundo ele, nenhum termo técnico definiria coletivamente (FINLEY, 1965, p. 51). Ele relaciona o significado de "dêmos" a esses últimos, aos "de baixo", àqueles que se encontravam abaixo da linha divisória que marcava a clivagem social, os inferiores. Espectadores passivos que, nas assembléias, às vezes protestavam ou aclamavam, mas que em geral permaneciam em silêncio (Ibid., p.101). A assembléia diz ele: 
"nem votava nem tomava decisões. A sua função era dupla: confrontar os argumentos prós e contras e exprimir ao rei ou ao comandante do campo a opinião predominante [...] O rei era livre de tomar ou não em conta os sentimentos expressos [...] A assembléia era para os reis um modo de testar a opinião pública, da mesma maneira que o conselho de anciãos exprimia o sentimento dos nobres."(FINLEY, 1965, p. 77-79).

No percurso Glotz - Finley, encontramos delineado o mesmo modelo. A sociedade homérica é bipartida, polarizada entre nobres e povo, composto pelo conjunto da população subordinada, aqueles sobre os quais a elite exerce o seu domínio e que seriam identificados pelos vocábulos "dêmos", "laós" e "plêthos". Embora variem no tom da escrita, chegam ao mesmo resultado. Explicitam uma operação analítica que, de tão comum, acaba passando por natural nos estudos homéricos. Identificam uma profunda divisão de classes na sociedade homérica, caracterizada de um lado pela existência de uma elite, que concentra o poder e a maior parte das riquezas, e de outro, uma multidão indefinida, vivendo diversas formas de subordinação à aristocracia. Uma vez aceita essa polarização, relacionam a multidão subordinada aos significados das palavras laós e dêmos. Nesse sentido, a cidade homérica seria pré-política. Nela o primado da coletividade ainda não teria se consolidado e a agorá ainda estaria longe do que ela viria se tornar no período clássico.

Se tomarmos como base a definição de Benveniste, vemos que nela tanto dêmos como laós expressam a idéia da totalidade do corpo social. Na utilização que Glotz e Finley apresentam dessas palavras, nas passagens selecionadas acima, dêmos e laós deixam de significar o todo e passam a identificar somente uma parte do corpo social: a ralé. Essas duas maneiras de conceber os seus significados não se apresentam como antagônicas na crítica historiográfica. Ambas são assumidas 
concomitantemente, dependendo do contexto em que estejam inseridas. Assim Dolan observa que usualmente dêmos designa a totalidade dos homens livres, excluindo os líderes (Ilíada.11.704; 18.490; 12.213; Odisséia 7.150; 8.157; 7.11; 16.645), porém também pode expressar a totalidade da comunidade (Ilíada 20.166; 11.328; 17.576-7; Odisséia 21.17).

A crítica apresenta o significado de dêmos transitando do todo para o particular e vice-versa, em um movimento de pêndulo que se ajustaria a cada contexto especifico em que a palavra estiver inserida. Nesse sentido as definições de Benveniste e de Glotz não se excluem, mas se harmonizam no interior do processo de interpretação. Os significados que Ihe são atribuídos por Cunliffe ilustram bem essa condição: (1) a district, (2) country, land, realm, (3) A community or people, (4) A body or force of mem, (5) A multitude, (6) The commom people. Nos itens 1 e 2, temos dêmos apresentado em seu aspecto geográfico, no item 3 expressando a idéia de comunidade, e no 6 significando somente uma parte dela, os homens comuns.

A nossa reflexão refere-se mais de perto aos sentidos apresentados nos itens 3 e 6. dêmos desdobrar-se-ia em seus dignificados ora designando o todo ora a parte. Porém tal se tal definição não apresenta controvérsias, devido ao grau de abstração com a qual está formulada, a mesma coisa não ocorre quando a preenchemos de conteúdos sociais. Qual seria a condição social dos que formariam a parte designada por dêmos?

Segundo Finley seriam a arraia-miúda, formada por pequenos proprietários de terra em estado de sujeição a uma minoria rica. Seria essa uma interpretação inconteste? O texto homérico seria passível de uma apropriação tal que nos 
permitiria chegar a conclusões seguras e fechadas, sem espaços para ambigüidades e incertezas? Quais seriam as possibilidades de interpretar a sociedade homérica em termos de estratificação social, atribuindo significados precisos para dêmos e laós?

Claude Mossé, em um comentário a respeito do significado de "dêmos" em Homero, embora comungue desse paradigma, acaba expressando que tal operação encerra problemas:

Quando evocam o démos do tempo de Sólon ou Pisístrato [ela diz], ou quando se trata nos poemas de Homero, do démos de Ítaca ou de Esquéria, é impossível saber a que se refere esse termo. Certamente em ambos os casos, trata-se da raia-miúda oposta aos poderosos. Ignoramos, as categorias sociais incluídas no démos: tetas e os artesãos fariam parte dele, ou apenas aqueles que viviam da terra, ou ainda os que tinham capacidade hoplítica. (MOSSÉ, 2004, p.90)

Ela afirma que é impossível saber ao certo a que se refere esse termo, porém, imediatamente, afirma que certamente seria formado pela raia-miúda. Mas em que sentido poder-se-ia afirmar que não se pode saber ao certo nada sobre o significado de "dêmos" e, ao mesmo tempo, afirmar que certamente seria formado pela raiamiúda? Parece que ela considera que não sabemos nada ao certo sobre "dêmos" por não podermos identificar quais as categorias sociais poderiam fazer parte dele. Porém, se ela não consegue definir socialmente quais as categorias que formariam parte do dêmos, como consegue definir que esse seria a raia-miúda, oposta aos nobres? O texto homérico suportaria de forma unívoca as acepções que dotam dêmos e laós com significações precisas, relacionando a um grupo social específico? 
Donlan (1999, p.225) observa que, em meados do quinto século, dêmos geralmente denotava a grande massa de cidadãos livres, grande em número, porém em situação social e econômica inferior a dos poucos ricos de bom nascimento. Porém, nos seus usos literários mais primitivos, ela não teria um sentido pejorativo, nem denotaria uma classe social inferior. Identificaria apenas o conjunto da população ora excluindo seus lideres, dando-Ihe um sentido de parte, ora incluindoos conferindo-Ihe a idéia de totalidade.

Halverson (1986) discorda da posição de Finley de que a sociedade itacense seria bipartida, opondo nobres de um lado e homens comuns do outro. Nela, nos diz, as tensões de classe não seriam proeminentes. A idéia de bipartição teria se estabelecido a partir da forma como dêmos e nobres são tratados como grupos separados na Odisséia 2.229ss e 16.375ss, porém não haveria razão para assumir que Homero teria retratado Ítaca de forma a caracterizá-la por uma profunda diferenciação social. Segundo ele, tanto os pretendentes como o dêmos pertenceriam ao mesmo grupo social. Eles não constituiriam o conjunto da população. Haveria também escravos, trabalhadores assalariados, mendigos, artistas e artesãos, porém nenhum deles estaria incluído no conceito de dêmos, não tomando assim parte do processo de decisões comunais. Dessa forma, teríamos na Odisséia a justaposição de um estrato aristocrático a um estrato servil, não havendo nada entre eles. Embora, segundo ele, a presença de pequenos agricultores em situação de sujeição fosse uma inferência possível a partir de Hesíodo, e historicamente plausível, a Odisséia não conteria referências a qualquer pequeno produtor em situação de dependência. Eles fariam parte de um mundo rural com a organização centrada na esfera do "oikos", em que não havia responsabilidades recíprocas entre as diversas famílias. O conflito em Ítaca seria entre uma geração 
mais nova e uma mais velha, entre a cidade e o campo e os seus sistemas de valores. Conflito que refletiria a percepção do poeta das mudanças que ocorriam em seu tempo. A importância do oikos tradicional viria diminuindo devido à concorrência que sofria de uma burguesia urbana e seus modos de vida e pensamento. Isso teria sido visto nostalgicamente por Homero que teria composto a Odisséia como um bastião do mais velho modo de vida, de uma época mais estável e mais idílica assentada nas comunidades agrárias, guiadas de maneira paternal pelos basileus. Desse modo, nas assembléias de Ítaca, haveria somente um grupo de homens representado, seja ele chamado de aqueus, laói ou dêmos. O grupo distinguir-se-ia da camada inferior, mas ele próprio não seria estratificado. Áristoi não seria uma designação de classe, mas identificaria somente os melhores no interior do dêmos. A liderança, no interior desse grupo, seria meramente circunstancial, não haveria um aparato legal que a sustentasse. O título de basileu não envolveria nenhum poder oficial, pois em Ítaca não havia nenhuma estrutura estatal organizada, nem uma ideologia da pólis. Portanto, para ele, não haveria nenhuma razão para se assumir uma distinção de classes na passagem em que Mentor recrimina o dêmos por permanecer em silêncio e não impedir o comportamento dos pretendentes. Ao aconselhar Telêmaco a convocar uma assembléia, ele diz, Atena qualifica os homens que deveriam ser convocados de "heróicos aqueus". São eles que estariam presentes na assembléia. É a eles que Mentor se dirige e, quando os censura não diz "eu censuro o dêmos", mas sim "não recrimino os pretendentes[...] eu censuro ao resto do dêmos". Se não dirige suas palavras aos pretendentes mas somente ao resto do démos, conclui, quem seria a outra parte? Para Halverson, a implicação lógica desta passagem é a de a outra parte só poder ser os próprios pretendentes. Assim para ele, o termo dêmos abarcaria a ambos os grupos. 
Geddes (1984) nos alerta para os perigos de relacionar o vocábulo dêmos a algum conteúdo social específico, por meio da identificação da sociedade homérica com qualquer sociedade real. Sua metodologia, para abordar a questão, consistiu em isolar os dois elementos básicos que a comporiam - o rei e o povo - e analisar o vocabulário empregado para designá-los, como também a forma com que é inserido no contexto social do poema. Para ele, a presença do povo comum em Homero é improvável e a realeza parece não ter nenhuma função.

Em sua análise do vocabulário usado para designar o povo, observa que Homero geralmente utiliza para tal fim as palavras laós, dêmos e plethos. Nenhuma delas teria um sentido político especializado, identificando uma classe social inferior. O laós e o dêmos seriam compostos não de uma classe mais baixa de pessoa, mas pelos que estariam, temporariamente, subservientes aos líderes. Como exemplo, arrola que Odisseu e Eurímaco referem-se a eles mesmos como laói ${ }^{20}$, e que démou

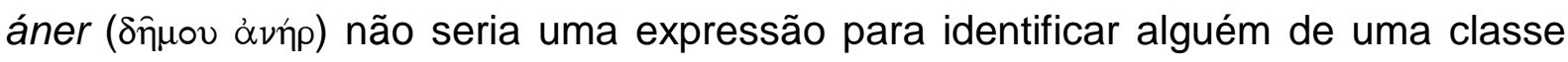
mais baixa, pois Polidamas refere-se a ele mesmo dessa maneira ${ }^{21}$, como também

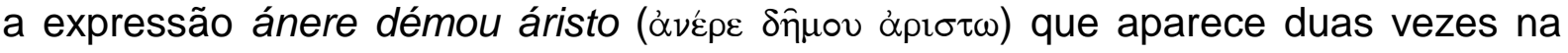
llíada.

Segundo ele, por parecer não haver um claro vocabulário técnico para se referir a uma classe mais baixa, muitos historiadores pontuam incidentes em que 0 comportamento dos personagens poderiam indicar consciência de diferenças de classes. O caso mais notório é o de Tersites. Segundo a crítica tradicional, ele teria

\footnotetext{
${ }^{20}$ Odisséia 9.263 e 15.519 respectivamente

${ }^{21}$ Odisséia 12.213.
} 
sido mal tratado por Odisseu, pois sendo um homem do povo, portanto de condição inferior, não deveria falar na assembléia. Porém, o autor lembra, o poema não registra sua origem, e a única coisa que menciona dele era que era feio. Geddes considera que a caracterização de Tersites tem uma função literária, semelhante a de Hefesto, que também era feio, porém não de nascimento inferior. Esse episódio seria supervalorizado pela carência de passagens que envolveriam representantes de homens livres das classes mais baixas.

Para Geddes, Homero não teria conhecido homens poderosos. Em sua época não haveria grande concentração de riqueza nas mãos de poucas pessoas às expensas de uma maioria pobre, tanto que, quando Homero retrata a riqueza de homens poderosos, ele parece ser ingênuo. Não encontrando indícios de classes baixas na llíada e na Odisséia, concluiu que ou na época de Homero não havia uma clara distinção de classes, ou seu poema não retrataria uma sociedade realmente existente.

\footnotetext{
"Quando Homero se refere ao povo, algumas vezes usa a palavra

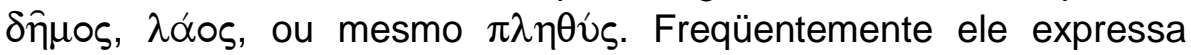
simplesmente o conjunto sem qualquer distinção social. Quando Apolo lança flechas sobre o campo aqueu, e os "laói" eram mortos, ninguém pode imaginar que o deus discriminou os mal nascidos e os bem nascidos. E quando, no escudo de Aquiles, os "laoi" iam para a assembléia, o poeta não intenta excluir os líderes. "Dêmos", de fato, freqüentemente refere-se ao território e ao povo que vive nele.
}

A dificuldade para se determinar significados precisos para os vocábulos dêmos e laós evidencia-se nesta discussão, a respeito de uma única fórmula em que essas duas palavras aparecem. Versando a respeito do povo nas assembléias homéricas, Trabulsi indaga quais seriam os termos que o designariam (lbid. , p.39). 
Ele nos fornece três respostas que se justapõem. Algumas vezes, ele, o povo, seria a multidão que resta, fora os nobres

\begin{abstract}
$\mathrm{Na}$ assembléia entre os feácios, Alcínoo foi chamado "rei que tem força e poder"; ele chama (verso 41) basileis as grandes personagens da cidade, que são chamadas com freqüência "doges e conselheiros da Feácia" (por exemplo, verso 97). Quando eles se dirigem aos jogos (versos 105-110), Homero distingue os chefes feácios (phaiékon hoi áristoi) da multidão, que acorria aos milhares, seguindo seus passos (polùs homilos, mírioi). (lbid., p.39)
\end{abstract}

Outras vezes, ele nos diz, seria o laós, e outras, o dêmos. Tanto laós como dêmos formariam um conjunto homogêneo e o uso desses dois termos seria intercambiável (Ibid., p.40). No que consistiria essa homogeneidade, somente é possível inferir a partir do exemplo que ele nos fornece em que o vocábulo dêmos apareceria de maneira menos uniforme, situação que ele exemplifica com a seguinte passagem: "Em III, 214-215, Nestor pergunta a Telêmaco se ele suporta aquela situação de plena vontade 'ou, no teu povo, tens o ódio de um partido'."

"Ou, no teu povo, tens o ódio de um partido" é a sua tradução para a fórmula $\hat{\eta}$

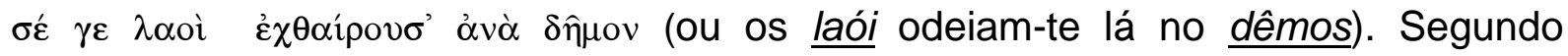
Trabulsi, nesses versos, laói teria o significado de "povo" e dêmos o de partido: "ou, no teu povo, tens o ódio de um partido"! Ele próprio manifesta desconforto pela opção. Embora consideremos que tenha sido traído pela sua fonte, pois não vemos de que maneira a tradução apresentada possa ser defendida, seu comentário a respeito dos versos é fecundo.

Partido é uma tradução talvez um pouco anacrônica, mas de qualquer forma aqui o démos é diferente de laós. Se ele não é uma 
parte do povo, com uma carga sócio-política específica, pelo menos ele é a emanação do todo, que tem opiniões e sentimentos diferentes. Parece que estamos quase na ambigüidade clássica, com démos sendo às vezes o conjunto, às vezes uma parte.(2001, p. 40, grifo nosso)

Trabulsi acha anacrônica a tradução partido para dêmos, apontando-lhe uma certa ambigüidade em seu significado, que ora expressaria o todo, ora a parte. Sua definição de que o povo, a parte submetida à nobreza, ora é o laós ora é o dêmos e que esses dois termos são sempre intercambiáveis, segundo ele mesmo define, não se sustenta nesses versos: "aqui o démos é diferente de laós", ele diz.

Sua explicação é resumida demais. dêmos seria o todo ou a parte do que? Do povo ou do conjunto da sociedade, incluindo os nobres. Nos parece que ele se refere ao conjunto do povo entendido como a fração que resta fora os nobres, com definido anteriormente por ele. Esses versos são citados como exemplo de sua afirmação de que em certas passagens dêmos seria menos uniforme, ou seja menos homogêneo. Mas lembremos, o argumento fornecido para justificar a não uniformidade, que se apresentaria no conjunto formado pelo dêmos, é que nessa passagem haveria a alusão de que pelo povo (dêmos) Telêmaco contaria com amizades e ódios. A não uniformidade aqui não se refere à condição social dos pertencentes ao conjunto, mas sim a opinião de seus membros, dos partidos que se formaram diante da questão. Para os objetivos de seu estudo, ele não necessita de uma precisa definição dessas palavras. Sua preocupação é a de mostrar que, na sociedade homérica, os líderes, no caso os reis, tinham a necessidade de mobilizar os seus comandados em favor de suas questões. Assim, para ele, não é de fundamental importância saber precisamente do que dêmos era parte ou um todo, e que tipo de fragmentação representaria sua idéia como partido. Para ele, basta que 
naquele contexto havia uma divergência de opinião em meio ao "povo", que esse não se constituía em um todo homogêneo e que, em seu corpo, poder-se-ia constituir fraturas que promovessem cisões e conflitos. Porém, apesar desse não ser o seu objetivo, pensamos que ele toca no centro da questão. Sua preocupação em buscar as linhas de fraturas, e a sua crença na necessidade da busca de consenso pela mobilização política levou-o a uma indagação importante: a palavra dêmos representa o todo ou a parte?

Scheide-Tissinier, analisando essa mesma passagem, observa que os laói não poderiam designar mais que os nobres que formam o grupo de pretendentes. Nesse caso, dêmos designaria a comunidade na qual todos os homens pertenceriam, no seio da qual distinguir-se-ia o rei e, muitas vezes, os nobres. No entendimento dessa passagem, ela não se prende ao conceito fechado de que dêmos, necessariamente, tenha o seu significado ligado à massa dos homens comuns. Aqui estaria expressando um conceito de comunidade que envolveria o conjunto da população.

A análise de Halverson dessa mesma fórmula - $\lambda \alpha o i$ óvò $\delta \hat{\eta} \mu o v$ chega à conclusão bem distinta de ambos. Para ele, nessa passagem, dêmos designaria "distrito" enquanto laói assumiria o significado de dêmos no sentido de identificar o conjunto do agrupamento. Pela tabela mostrada abaixo, podemos visualizar o grau da variação que apresentam. Neles laói aparece como "o povo comum", os pretendentes, e o conjunto da comunidade. dêmos, como partido, a comunidade e distrito. 


\begin{tabular}{|l|l|l|}
\cline { 2 - 3 } \multicolumn{1}{c|}{} & Laói & dêmos \\
\hline Trabulsi & O povo comum & Partido \\
\hline Scheide-Tissinier & Pretendentes & A comunidade \\
\hline Halverson & A comunidade & Distrito \\
\hline
\end{tabular}

O quadro de discordância, que esses três estudiosos apresentam, reflete a dificuldade para se definir os significados de dêmos e laós, quando o contexto em que elas são empregadas se apresenta indefinido. Benveniste define dêmos como um conceito geográfico e humano, porém notamos que, em suas análises, ScheidTissinier opta pelo conceito de agrupamento humano e Halverson pelo geográfico. Laói é definido por Benveniste como o povo em armas, porém Trabulsi, Halverson e Scheid-Tissinier discordam quanto quem seria esse povo?

Seria o caso das cenas de assembléia diferente? O vocábulo dêmos, quando empregado nesses episódios, teria o significado de "povo comum", uma delimitação geográfica ou denominaria o conjunto da comunidade? Quais seriam as possibilidades de se chegar a uma descrição da organização social da sociedade homérica a partir da determinação precisa dos significados das palavras dêmos e laós? 
3 - A ÁGORA E OS LIMITES DA VIDA CIVILIZADA 


\section{1 - Desmedidos, selvagens e injustos: o tema da ausência de laços de sociabilidade}

Se o épos tem na organização de assembléias deliberativas um dos marcos da formação da coletividade, nele também encontra, por meio do relato que Odisseu faz de suas errâncias, o exemplo de um povo que não possuía uma agorá: os Ciclopes. Qual seria o significado dessa ausência?

Trabulsi (2001, p.24) estabelece a agorá, a praça pública, como elemento definidor demarcatório do campo do que é civilizado em oposição ao que é considerado selvagem e bárbaro. Assim, os Ciclopes seriam selvagens por não terem assembléias para deliberar. Segundo ele, poder-se-ia mesmo aproximar o verso Odisséia 9.112, em que se apresenta a formulação a respeito da ausência de agorá entre os Ciclopes, da observação contida em Heródoto em relação aos bárbaros, no livro I,153. A passagem em questão refere-se à resposta que Ciro deu a emissários espartanos que lhe dirigiram uma advertência para que não prejudicasse os Jônios. A resposta de Ciro foi contundente

Nunca temi homens que têm no centro de sua cidade um local para reunir-se e enganar-se uns aos outros com juramentos. Homens assim, se eu conservar minha saúde, terão oportuni- 
dade de tagarelar não sobre os infortúnios dos iônios, mas sobre os seus próprios infortúnios ${ }^{1}$.

Com essas palavras, nos diz Heródoto, Ciro "insultou todos os helenos, pois eles têm suas ágoras"2. Trabulsi demarca assim dois campos: civilizados de um lado, selvagens e bárbaros de outro. Benveniste (1995b, p.) também define os Ciclopes como selvagens: um povo cuja organização não ia além da esfera familiar. Entre eles, nos diz, cada qual ditava a lei às sua esposa e filhos, cada família vivia sobre sua própria lei. Não se organizavam em genos, e onde não existe genos, conclui, também não existe rei, nem themis (lei), nem assembléia”. Para Glotz (1988, p.43), a agorá "completa as instituições que parecem necessárias à própria existência da cidade sem as quais os homens não passam de selvagens que vivem como os Ciclopes”. Também, nesse sentido , Clay (1980, p.126) afirma categoricamente: os Ciclopes são pré-políticos e primitivos, não deliberam publicamente e não possuem agorá. Finley (1965, p.75) aponta que a ausência da assembléia entre os Ciclopes é considerada por Odisseu como um dos elementos que indicavam o estágio não evoluído desse povo. Runciman (1982, p.352) compara os Ciclopes às agregações de casas patriarcais autônomas que teriam ultrapassado o estágio das sociedades sem estado das primitivas reuniões de caçadores, pastores nômades e cultivadores de roças. Segundo Posner (1979, p.40), os Ciclopes seriam a contrapartida, no mundo homérico, do "estado de natureza" de Hobbes . Contra a visão dessa existência bár-

\footnotetext{
${ }^{1}$ Trad. Mário da Gama Kury.

2 Idem.
} 
bara, diz ele, o épos colocaria a de uma vida civilizada, na qual os requisitos da harmonia social seriam determinados pela rede de interações entre as casas patriarcais. Glotz, Benveniste, Finley, Clay, Runciman, Posner e Trabulsi expressam um ponto de vista comum. Para eles, os Ciclopes possuem uma organização fundada na estrutura familiar, cujas unidades não formam uma comunidade mais ampla, não constituindo, assim, assembléias deliberativas para tratarem de assuntos comuns e estabelecerem regras e leis entre si.

Os Ciclopes são caracterizados pela crítica como um povo selvagem que não contaria com as formas associativas que definem a vida coletiva em uma Cidadeestado, não havendo entre eles a presença de sua instituição básica: as assembléias deliberativas. O confronto entre Odisseu e Polifemo, o ciclope, marcaria assim uma espécie de oposição entre a forma de vida civilizada representada por Odisseu, de um lado, e o mundo selvagem representado por Polifemo, de outro. Porém, a oposição entre vida civilizada e vida selvagem, marcando a interpretação da narrativa dos Ciclopes, exige cuidados. Selvagens e não civilizados foram considerados os que se tornaram objeto dos empreendimentos imperialista das potências capitalistas do século XIX. É no âmbito desse movimento que conceitos antropológicos foram cristalizados com a finalidade de explicar as sociedades tribais com as quais europeus e norte-americanos se depararam em seus processos de expansão econômica e territorial. Vistas como rústicas e não refinadas, as sociedades constituídas por esses povos eram interpretadas contra o pano de fundo dos valores da sociedade européia, alçada a modelo de vida civilizada. Nesse sentido, as formas econômicas, sociais e políticas caracterizadoras das sociedades européias tornam-se os próprios elementos da civilização. As sociedades que não apresentassem essas mesmas 
características seriam as não civilizadas, sociedades primitivas, bárbaras ou selvagens.

Procurando definir os significados possíveis, que modernamente encerrariam o conceito de civilização, Francis Wolff (2000, p.21) identifica três sentidos diferentes para o termo

1. civilização designa tudo aquilo que, nos costumes, em especial nas relações com outros homens e outras sociedades, parece humano, realmente humano - o que pressupõe respeito pelo outro, assistência, cooperação, compaixão, conciliação e pacificação das relações -, em oposição ao que se supõe natural ou bestial, a uma violência vista como primitiva ou arcaica, a uma luta impiedosa pela vida. Os bárbaros são descritos como bichos do mato, dotados de uma brutalidade feroz, cega e selvagem, sem motivo razoável e, sobretudo, se limite racional.

2. civilização designa as ciências, as letras e as artes, em suma, o patrimônio mais elevado de uma sociedade.

3. civilização designa um processo, supostamente progressivo, pelo qual os povos são libertados dos costumes grosseiros e rudimentares das sociedades tradicionais e fechadas para se civilizar, o que supõe a pertença a uma sociedade maior, aberta e complexa e , portanto, urbanizada [...] A urbe, com efeito, é ao mesmo tempo a cidade, a pólis, espaço de relações variadas, e a sociedade em geral é o espaço de intersecção entre a urbanidade e a cidadania. $O$ bárbaro supostamente se inclui num estágio inferior da evolução política, num estágio pré-civil ou, pelo menos, pré-urbano. (grifo nosso)

Em que medida poder-se-ia entender a oposição entre Odisseu e Polifemo como uma contraposição entre o civilizado e o selvagem, nos sentidos apontados por Wolff? Nesse caso, os Ciclopes seriam seres (1) sem compaixão, não dispostos a cooperação, (2) sem apreço aos altos valores, como por exemplo a observância da piedade religiosa e (3) com costumes grotescos. E qual seria a relação existente 
entre os modos selvagens dos Ciclopes e a ausência de assembléias deliberativas entre eles?

Wolff, ao comentar o sentido de civilização que apresentamos no item 3 acima, observa que há estreita relação entre esse conceito e as formas de organização social que ele implicaria. Sua observação, embora feita de forma genérica, de que o bárbaro se insere em um estágio inferior de organização política, evidencia um aspecto de suma importância nesta discussão: o da associação entre formas de organização da vida comunitária, vistas como pré-políticas, e a constituição de modos de vida considerados como selvagens.

A vinculação entre práticas associativas e econômicas, que seriam típicas dos modos de vida não civilizada, encontra-se na base das formulações expostas acima, que vinculam a ausência de assembléias deliberativas entre os Ciclopes e a figuração dos mesmos como selvagens pela narrativa. Nesse sentido, a afirmação categórica de Trabulsi é exemplar de tal procedimento: os Ciclopes são selvagens por não terem assembléias para deliberar. Desse modo, já se espelharia assim, na épica, um conceito de "selvagem" que se desdobraria para significados sócio-políticos que preencheriam de sentido o adjetivo, a tal ponto que se poderia afirmar que o julgamento de Odisseu, apresentando os Ciclopes como selvagens, estaria assentado na ausência de assembléias entre eles? 
Quando Odisseu se prepara para ir averiguar quem era o povo que habitava a terra, que depois veio saber ser a dos Ciclopes, ele se pergunta: "Serão desmedidos, selvagens e injustos, ou hospitaleiros, tementes aos deuses"3.

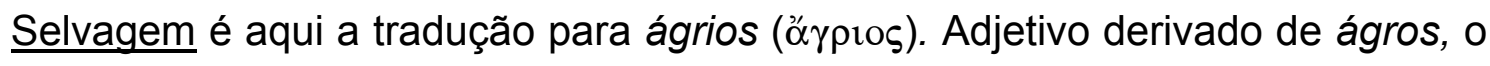
"campo" por oposição a vila. A palavra é empregada em diversas situações. Aparece associada a animais selvagens, como cabras, javalis e leões ${ }^{4}$. Em sentido figurado, assume o significado de feroz, violento, qualificando a ferocidade de seres monstruosos, como Cila, os Gigantes e Polifemo ${ }^{5}$, ou a de guerreiros em batalha, como Diomedes, Heitor e Aquiles ${ }^{6}$. Selvagem é a força do fogo destruidor e da batalha sangrenta, sentido apreendido de forma magnífica no símile reproduzido abaixo

\begin{abstract}
A batalha alastrava-se, selvagem (光plos), como o fogo que, propagando-se na cidade povoada onde surgiu bruscamente, flameja, e faz aluir as casas no meio do seu clarão imenso: sobre ele brame a força do vento.?
\end{abstract}

Em seu sentido figurado, o adjetivo "selvagem" deve ser entendido como uma ferocidade avassaladora, com grande capacidade de destruição. Agressividade que, ao se liberar, leva seu portador aos liames do comportamento aceitável. Assim Diomedes, no auge de sua agressividade guerreira, no afã de matar Enéas, despojan-

\footnotetext{
${ }^{3}$ Odisséia 9.175-76.

${ }^{4}$ Ilíada3.24; 4.106; 5.52; 8.338; 9.539; 15.271; 24.41; Odisséia 9.119; 14.50.

${ }^{5}$ Odisséia 7.206; 9.215, 494; 12.119.

${ }^{6}$ Ilíada 6.97,278; 8.95; 21.314.

7 Ilíada.17.737-39.
} 
do-o de suas armas, investe três vezes contra Apolo, que prestava auxílio ao troiano. Quando então avança, como se fosse um deus, pela quarta vez, Apolo lhe adverte:

Acautela-te, filho de Tideu, e retira-te; não pretenda formar os mesmos pensamentos que os deuses, pois nunca foram semelhantes a raça dos deuses e a dos homens que andam pela terra." ${ }^{8}$

Diomedes, levado por sua fúria guerreira, comete excesso, ultrapassando os limites que separam deuses e homens. Rompe a medida do humano, comportandose de maneira inapropriada, não sendo justo e adequado e ofendendo a própria ordem divina. Aqueles que ultrapassam a medida do que é justo são desmedidos

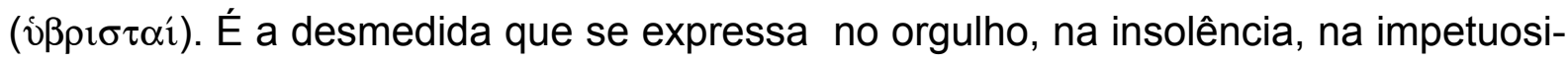
dade, na violência ou na não observância dos preceitos divinos. Quem a prática rompe com a justiça (díke), que mantém o equilíbrio das partes, sendo assim ádikos

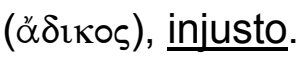

A cólera selvagem, incontida, desmedida e avassaladora, que motiva comportamento injusto, está na base mesmo da heroicidade configuradora dos principais personagens na llíada. Esse é o caso de Agamêmnom que, ao não conseguir se conter, ofende Aquiles. Comportamento desmedido que o leva a tratar o grande herói de maneira injusta. Enfurecido, Aquiles clama por vingança, até que sua honra seja restabelecida. Embora apresentado em um esquema formular distinto não seria

\footnotetext{
${ }^{8}$ Ilíada 5.440-2.
} 
o tema da cólera incontida o próprio tema do canto que o aedo invoca a Musa a cantar: "A ira do Pelíada Aquiles, canta, oh deusa". A agressividade selvagem de conseqüências hibrísticas está na base do comportamento heróico que visa a recuperação da honra perdida ou ameaçada na Ilíada. Na Odisséia o tema da cólera selvagem também está presente, porém é controlada em nome da conveniência de não se agir de maneira impulsiva. Assim, Atena, diante das censuras de Zeus, por duas vezes, vendo-se tomada por cólera selvagem, contém-se e fica calada. Ela conhece o seu lugar e não ousa enfrentar Zeus, que além de ser seu pai, supera-lhe em força. Odisseu também apresenta tal capacidade de controlar a raiva. Assim ele o faz quando está preso na caverna de Polifemo e quando se encontra em sua própria casa, disfarçado de mendigo, a espera do melhor momento para atacar os pretendentes. Clay (Ibid. p.113) observa que o confronto entre Polifemo e Odisseu marcaria a oposição entre bie e metis, com esta última representando mais do que a astúcia necessária para se escapar do ogro, mas também as artes e as habilidades da civilização. A técnica que seria contrastada com a falta de tecnologia e vida civilizada. Para Clay, o autocontrole é uma das componentes principais da astúcia de Odisseu, pois somente por meio dele é possível ter a paciência necessária para esperar o melhor momento para agir. Assim, para ela, a aventura dos Ciclopes marcaria o triunfo da inteligência e o autocontrole sobre a força e o impulso (Ibid., p.125). Segundo Segal (1962, p.34), o revés sofrido pelo Ciclope seria uma vitória da inteligência humana sobre as forças primitivas da natureza indomada.

O adjetivo selvagem (ágrios) quando relacionado à aos deuses (no caso específico a Atena), aos heróis guerreiros nos campos de Tróia e ao fogo devorador aparece em sentido figurado da ferocidade incontida, desmedida, que não sendo apro- 
priada para o comportamento humano, mas típica das feras do campo, é qualificada de injusta.

Nos versos em questão, o sentido de "selvagens, injustos e desmedidos" é completado pelos elementos que lhes são postos em oposição: a hospitalidade e a observância do comportamento piedoso. Os Ciclopes seriam selvagens ou hospitaleiros e piedosos. Tal contraposição sinaliza, pelo menos em um primeiro nível de observação, que a narrativa, com o vocábulo selvagem (ágrios) estaria se referindo a aspectos comportamentais e não à estrutura sócio-econômica que o caracterizaria. Se tomadas como bases referências as observações de Wolff a respeito dos possíveis significados que a palavra "selvagem" encerraria modernamente, pode-se aceitar que, nesses versos, o vocábulo ágrios (selvagem) estaria próximo dos sentidos apresentados nos itens 1 e 2: (1) não cooperativos e (2) impiedosos.

"Serão desmedidos, selvagens e injustos?" Os versos 175-76, nos quais são apresentadas as preocupações de Odisseu quanto à natureza dos Ciclopes, são formulares. Dessa mesma maneira, Odisseu se indaga quando chega à terra dos feácios ${ }^{9}$. Assim também Alcínoo, ao pedir-lhe que narrasse suas aventuras, solicita para que falasse não somente das cidades bem construídas, mas que também contasse a respeito dos "desmedidos, selvagens e injustos, como dos hospitaleiros, e os que abrigam na mente temor aos deuses"10.

\footnotetext{
${ }^{9}$ Odisséia 6.120-21.

${ }^{10}$ Odisséia 8.572-77.
} 
O tema também está presente quando Odisseu é deixado em Ítaca pelos Feácios. Para que não fosse reconhecido, Atena vertera uma névoa ao seu redor, assim, ao despertar do sono em que se encontrava, tudo the parece estranho, não conseguindo reconhecer sua terra. "Ai de mim! À terra de que mortais chego desta vez? Serão desmedidos, selvagens e injustos? ou de índole hospitaleira, temente aos deuses?"11. Odisseu, ao não reconhecer a terra natal, sente-se um estrangeiro e, diante do desconhecido, preocupa-se. Ser bem recebido é uma questão importante para aqueles que se encontram em terras estranhas. A hospitalidade aos que batem à porta é de grande valia para alguém perdido e necessitado. No imaginário épico, os próprios deuses tomam feições de viajantes estrangeiros, percorrendo cidades e campos, para testar a piedade dos homens ${ }^{12}$. A não observância desse preceito é considerada afronta ao próprio $Z e u s^{13}$, uma vez que os hóspedes são seus protegidos, e aqueles que Ihes são hostis, apresentando um comportamento feroz, são desmedidos e injustos.

Por meio de uma linha de caráter moral, dividindo em dois os tipos de gente que se poderia encontrar, os justos e os não-justos, esses versos formulares estabelecem dois campos opostos de comportamentos, separando dois modos distintos de tratar com os estrangeiros. De um lado, estão aqueles que Ihes são amigos, os hos-

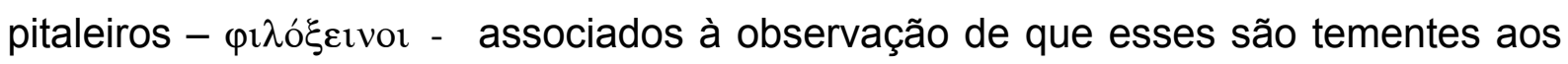

\footnotetext{
11 Odisséia 13.200-02.

12 Odisséia 17.485-87

13 Ilíada 13.624.
} 
deuses. De outro, estão os selvagens, os desmedidos e injustos, guardando uma relação de exclusão com os primeiros.

Tido como exemplo máximo de selvageria e hostilidade aos estrangeiros, Polifemo, o ciclope, é considerado o maior transgressor da prática da hospitalidade na Odisséia. Ao ser solicitado por Odisseu para que mostrasse piedade, tratando-lhes bem, pois os suplicantes e os hóspedes estariam sob o amparo de Zeus, fornece como resposta que era ingenuidade evocar o deus, pois não o temia, já que se considerava mais forte:

Os Ciclopes não se preocupam com Zeus portador da égide, nem com os deuses bem aventurados, pois nós somos-lhes, certamente, muito superiores. Eu próprio não te pouparia nem a ti nem aos teus companheiros para evitar o rancor de Zeus, mas apenas se o meu coração a tal me impelisse. ${ }^{14}$

Suas palavras são manifestação clara de arrogância e impiedade, e o seu comportamento foi brutal. Após dar a resposta a Odisseu, Polifemo come dois de seus companheiros, pervertendo a regra da hospitalidade. Seu comportamento hostil, o coloca entre os desmedidos, selvagens e injustos.

Afirmou-se acima que, em um primeiro nível de observação, o adjetivo ágrios (selvagem) estaria sendo empregado no sentido figurado de ferocidade, que na fórmula em questão se opõe ao que é hospitaleiro e piedoso. Nesse caso, a conclusão

${ }^{14}$ Odisséia 9.273-278. 
lógica seria a de que Polifemo seria um selvagem, pois não se comporta de maneira hospitaleira para com os estrangeiros. Porém, a crítica historiográfica, quando busca delinear os contornos da sociedade homérica, costuma apontar que os Ciclopes seriam selvagens por não possuírem agorá, o que a aproximaria à observação de Wolff apresentada no item 3 acima, no qual comenta a vinculação entre o conceito de selvagem e estruturas sócio-políticas específicas. Qual seria então a relação entre julgamento que Odisseu faz de Polifemo, apresentando-o como selvagem e a ausência de agorá entre os Ciclopes?

Polifemo é um selvagem que não participa das condutas próprias do humano. Ele não tem esposa e filhos. É descrito como um homem monstruoso que, sozinho, leva suas cabras para pastos afastados, não mantendo contato com os outros. Ele é um ser monstruoso que não estabelece laços de sociabilidade internos com seus iguais, nem externos, com estrangeiros. Sendo solitário é taxado de iníquo.

Abrigava-se ali [na caverna] um homem gigantesco, que apascentava as suas ovelhas sozinho, longe dos outros, pois não convivia com eles e mantinha-se à margem, não conhecendo lei alguma. ${ }^{15}$

O tema do homem sem regras e sem família possui ressonância com as palavras proferidas por Nestor, na llíada. "Sem fratria, nem leis, nem lar é aquele que deseja a horrível guerra civil", diz ele ${ }^{16}$.

${ }^{15}$ Odisséia 9.187-9. 
A expressão "guerra civil" é a tradução aqui adotada para o vocábulo epidemí-

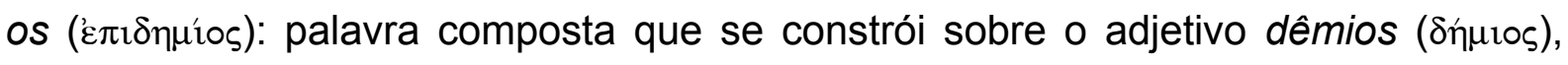
que tem por significado público, comunal, do povo.

"Sem regras/leis" é tradução para athêmistos. Athêmistos é aquele que não possui thêmistes, plural da palavra thêmis, que tem por significado "o que é estabelecido como regra" ${ }^{17}$. Elas são as sentenças ditadas por reis e juízes. Hesíodo nos informa que a deusa Thêmis, personificação divina do conceito, gerou de Zeus as três moiras, deusas ligadas à idéia de destino, e as três Horas - Eqüidade (Eủvopínv),

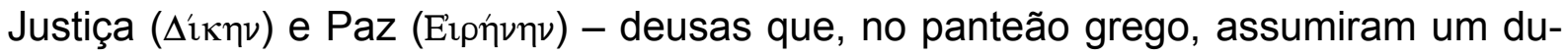
plo aspecto: como divindades da natureza, presidem ao ciclo da vegetação, como divindades da ordem, asseguram a estabilidade social. Para Benveniste (1995, p.101-6) tal idéia de "ordem" seria uma das noções cardeais do universo jurídico, religioso e moral dos indo-europeus. "Ordem" que governaria tanto a disposição do universo, a periodicidade das estações, como as relações entre homens e deuses, e dos homens entre si. Segundo ele, nesse universo, nada que se referisse ao homem e ao mundo escaparia a ela. "Fundamento religioso e moral de toda sociedade, diz ele, sem esse princípio, tudo retornaria ao caos".

A idéia de thêmis projeta-se sobre os aspectos relacionados à sociabilidade, regulando as relações entre os homens e entre esses e os deuses. Ela é um atributo de Zeus. É ele quem as fornece aos juízes, quando das contendas nas assem-

\footnotetext{
${ }^{16}$ Ilíada 9.63-4.

17 Bailly, s.v.
} 
bléias. Apanágio da soberania, os reis recebem-nas para que possam governar $(\beta o v ́ \lambda o \mu \alpha \mathrm{l})^{18}$. Agamêmnon recebe o cetro e as thêmistes de Zeus ${ }^{19}$. Odisseu diz que somente um deve ser rei: aquele a quem o descendente de Crono deu o cetro e as thêmistes ${ }^{20}$.

Hesíodo associa à Musa, que preside a eloqüência, a capacidade dos reis para ditarem thêmistes justas, quando, falando firmemente nas assembléias, põem fim as discórdias com palavras brandas ${ }^{21}$.

O exercício das thêmistes está associado a privilégios e deveres. Agamêmnom, ao oferecer uma cidade de presente, para que Aquiles voltasse a combater entre eles, afirma que os muitos senhores que estariam submetidos às suas thêmistes lhe proporcionariam copiosos tributos ${ }^{22}$. Mas seu exercício não está isento de responsabilidades. Zeus pune os que distorcem a thêmis, afastando assim do que é justo (díke).

Tal como a terra, obscurecida, é toda ela esmagada por uma tempestade, num dia de Outono, sob a água que deus verte com violência, quando, no seu ressentimento, ele se zanga com os homens que, por violência, na praça pública, pronunciam sentenças imperfeitas e suprimem a justiça, sem temer o olhar dos deuses: todos os rios engrossam nos seus leitos; são então numerosas as vertentes devastadas pelas torrentes que, do alto das montanhas correm com

\footnotetext{
18 Ilíada 2.206; 9.99

19 llíada 9.99.

20 llíada 2.206.

21 Theog.80-91.

22 Ilíada 9.156-8.
} 
grande ruído para o mar purpúreo, e devastam os trabalhos dos homens. $^{23}$

Na Odisséia, os pretendentes também são qualificados de athêmistos. Quando Odisseu está em sua casa, disfarçado de mendigo, Atena incita-o a pedir comida a eles, para saber quem eram os sensatos, que agiam de acordo com a regra ditada

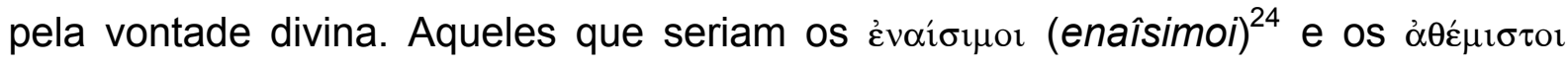
(sem thêmis). Ctesipo, um dos pretendentes, é taxado de athêmistia ao ser relatado que ele, desrespeitando o mendigo, no caso Odisseu disfarçado, atira-lhe um pé de boi.

Odisseu, ainda como mendigo, profere um discurso entre os pretendentes, com a intenção de advertir um deles para que fosse embora, e assim poupasse sua vida. Para convencê-lo, conta-lhe que, antes de ter se tornado mendigo, teve também a sorte de viver contente no seio de uma família rica e forte, mas que, confiado na força do pai e dos irmãos, era violento e praticara muitas loucuras ( $\left.\pi \circ \lambda \lambda \dot{\alpha} \delta^{\prime} \dot{\alpha} \tau \alpha \dot{\alpha} \sigma \theta \alpha \lambda \alpha\right)$. Odisseu termina seu discurso apelando para que nenhum homem venha ser athêmistos e que cada um venha gozar em silêncio os bens proporcionados pelos deuses. A advertência dirige-se diretamente para o comportamento dos pretendentes. Na seqüência, utilizando a mesma palavra empregada anteriormente para qualificar

\footnotetext{
${ }^{23}$ llíada 384-93.

${ }^{24}$ Enaîsimoi é um vocábulo difícil para ser traduzido devido ao fato da idéia de regra e lei modernamente não possuir a dimensão divina como se apresenta nos poemas homéricos. Enaîsimoi se compõe de en + aîsa que significa "decisão ou vontade de deus", de onde regra, leit, conveniência, destino e sorte. Assim enaisîmoi é aquele que compartilha da vontade divina, o conveniente, o justo e o honesto.
} 
os seus comportamentos, observa que os pretendentes estavam praticando loucuras $(\alpha \tau \alpha \sigma \theta \theta \lambda \alpha \alpha)$ ao consumirem os bens e desrespeitarem a esposa de Odisseu.

Associado à idéia de thêmis, tem-se a realeza, o governo, as assembléias, a justiça, a boa regra, a paz, a prática da hospitalidade e o respeito à casa e a esposa dos outros. As thêmistes participam da esfera da sociabilidade, regulando o conjunto de relações que envolvem a vida em comunidade. São expressões da soberania de Zeus e da partilha instituída entre deuses e homens. Athêmistos, os iníquos, são aqueles que de alguma forma ferem esta ordem colocando-se à margem de alguma regra de convivência.

"Sem lar" é a tradução adotada para anêstios, negação de héstia, a lareira. Parte íntima da casa onde se acha o altar dos deuses domésticos, que, por extensão acaba designando a própria moradia. Hestiáo, verbo derivado de héstia, tem por significado "receber à mesa". A deusa Héstia, protetora do fogo doméstico, simboliza a casa no seu sentido mais amplo, envolvendo os antepassados e os familiares que prestam o culto e comem à mesma mesa.

"Sem fratria" é tradução para ỏ $\varphi \rho \eta ́ \tau \omega \rho ~(a p h r \underline{e} \underline{t o r})^{25}$. Uma palavra isolada na épica, que não permite uma definição precisa de seus significados. Chantraine (1968)

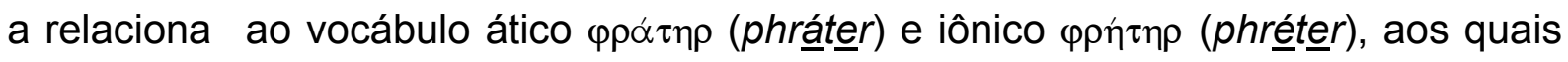

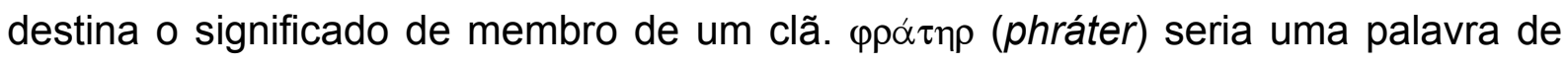
origem indo-européia que teria o significado de irmão. Em grego, esse sentido antigo

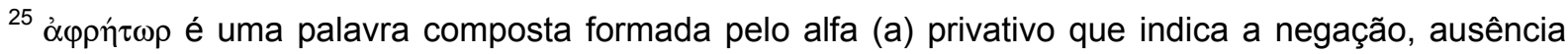

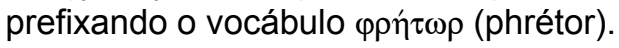


de irmãos de sangue não seria atestado nos textos conservados, noção que neles

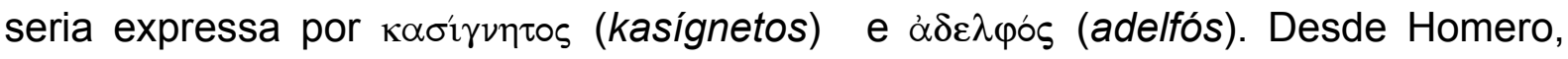

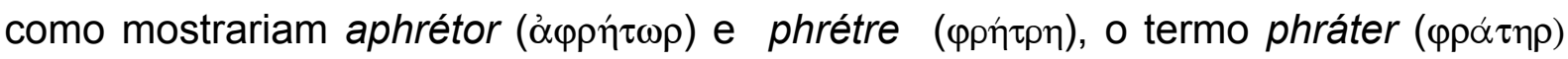
designaria os membros de uma associação de camaradagem e solidariedade, constituídas de gens que pertenceriam a famílias aliadas ou simplesmente vizinhas, cujos membros considerar-se-iam irmãos.

Andrews adverte para as dificuldades de se obter uma precisa definição dos tipos de relações sociais que encerrariam a fratria homérica. Tais dificuldades originar-se-iam do fato de, nas duas únicas passagens em que há a ocorrência do vocábulo na épica, elas estarem isoladas em seus contextos. No caso desses versos, Nestor profere suas palavras após Diomedes ter contestado a proposta de retornarem para casa feita por Agamêmnom. Segundo Andrews, essa seria uma observação muito exagerada para a ocasião em que foi proferida e, naturalmente, tem sido vista como uma interpolação sem solução de continuidade com seu contexto imediato. A intrusão desses versos na llíada remontaria aos fins século IX e inícios do VIII, um tempo em que fratrias, thêmistes e lar fariam parte do aparato regular da vida e não seria usual que um homem não participasse dessas esferas de organização.

Assim, a fratria retratada no poema ter-se-ia organizado em meio ao mundo aristocrático dos inícios do século VIII, longe suficiente de Homero para serem aceitas como características de seu ambiente, porém após o período formativo das convenções épicas, séculos X e XI, época das migrações ocorridas no âmbito da derrocada do mundo micênico. Desagregadoras, as migrações teriam contribuído para a criação de bandos cuja coesão fundamentar-se-ia na capacidade do líder para criar con-

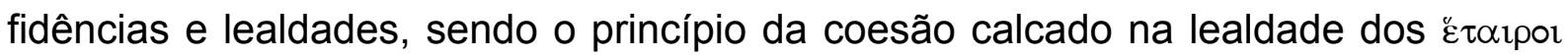


aos seus líderes, e não em laços familiares. Nesse sentido, nos diz Andrews, embora o parentesco seja um princípio importante, na épica, ele não se constituiria em base de organização nem para a tropa, nem para a vida civil, exceto no verso em questão.(lbid., p.137).

Andrews parte do princípio que durante o processo de composição da llíada e da Odisséia, até que os poemas se cristalizassem na forma como nós os conhecemos, durante o século X e XI, eles teriam passado por constantes mudanças. Seria no âmbito dessas transformações que a tradição teria remodelado a figura de Agamêmnon de um rei micênico para um "líder jônico do período das migrações". A trama da llíada teria obrigado a tradição a fazer Agamêmnom senhor de outros reis, uma situação difícil de ser imaginada nesse período, uma vez que essa realidade desaparecera no passado com a derrocada do mundo micênico. Então, o que teria ocorrido no processo de composição é que algum poeta criativo deve ter modelado a relação entre Agamêmnom e seus seguidores de forma mais inteligível para sua época (século X), caracterizando-o de acordo com algum líder da migração jônica. Porém, nos diz ele, quando cessaram as migrações e a sociedade se reassentou, com a aristocracia tornando-se mais forte do que o rei, a convenção formada no contexto do século XI não sofreu remodelações para se adequar às novas circunstâncias, pois, nos inícios do período arcaico, elas seriam mais firmemente estruturadas e portanto menos apropriadas como pano de fundo para a ação dos heróis.

A outra passagem em que a palavra phrétre é utilizada refere-se à advertência de Nestor a respeito de como Agamêmnom deveria organizar as tropas para a bata- 
Iha. "Agamêmnon, separe os homens por tribos (phyla) e por fratrias (phrétras), para que a fratria (phrétre) auxilie a fratria e as tribos, as tribos", ele diz ${ }^{26}$

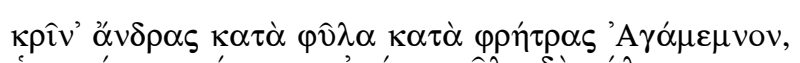

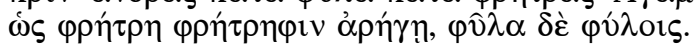

Segundo Nestor, vantagens de organizá-los dessa maneira seria que assim Agamêmnom saberia quem dos líderes e quem dos comandados seria valente ou não, podendo desse modo estimar se Tróia resistia por vontade dos deuses ou por covardia $^{27}$.

Os homens, tanto os líderes como os comandados, a quem Nestor se refere são guerreiros e fazem parte da tropa reunida por Agamêmnon, do seu laós. Nessa passagem, o vocábulo phrétre, empregado associado a phyla, aparece como algum tipo de agrupamento no qual o laós se subdividia. Mas se phrétre é uma subdivisão do laós. Mas qual seria a sua relação com phyla?

A organização do laós subdividido em tribos (phyla), aludida por Nestor, também aparece como um princípio organizador na fundação de Ródes por Tlepólemos. No Catálogo das Naus, informa-se que ele, após ter matado seu tio materno, receando a vingança dos parentes ofendidos, reuniu o laós e fugiu. Conseguindo chegar a Rodes, lá se estabeleceu, dividindo-os em três povoamentos, segundo as tribos

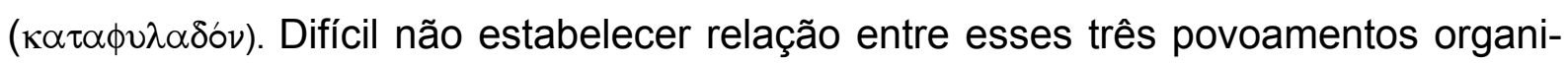

\footnotetext{
${ }^{26}$ Ilíada 2.362-3

27 Ilíada 2.364.8.
} 
zados por tribos, citado no verso 668 , e a observação, nos versos $653-6$, de que eles, divididos em três grupos, residem em Lindo, laliso e Cameiro.

Tlepólemos, descendente de Heracles, valente e alto, tinha levado de Rodes nove naus de Ródios soberbos, que habitavam a região de Rodes, divididos em três grupos, Lindo, láliso e a branca Camiro[...] (2.668-9)[Tlepólemos com seu laós] chegou a Rodes, errante e sofredor; e eles estabeleceram-se ali, divididos em três tribos.

Qual seria o princípio organizativo que teria levado Tlepólemos a separar seu laós em três grupos distintos? Seriam os mesmos critérios que Agamêmnon utilizaria para organizar seu laós em tribos (phylas) e fratrias? Que tipo de identidade eles comungariam entre $\mathrm{si}^{28} ?$

Phyla (tribo) é um vocábulo empregado com maior freqüência na épica do que phrétre, o que nos fornece a possibilidade da análise temático-formular de sua ocorrência e, a partir dela, tentar inferir suas significações sociais. Um de seus empregos mais interessantes, pelos caminhos que nos propicia, é o do tema da mosca. Em Iliada.19.30, temos: "tratarei de afastar dele estas tribos selvagens, estas moscas que devoram os homens vítimas de Ares" ${ }^{29}$. Com essas palavras, Tétis diz a Aquiles

\footnotetext{
${ }^{28}$ Scheid-Tissienier utiliza essa passagem para argumentar a favor da vinculação existente entre o conceito laós e o de dêmos. São com os elementos do laós que Tlepólemos funda o dêmos de Rodes, segundo ela. Por sua vez Donlan observa que Tlepónemos não teria reunido o seu laós ao acaso. Segundo ele, supõe-se que Tlepónemos incluiria algumas famílias e elementos isolados em seu bando, porém ele não teria operado o recrutamento ao acaso, mas o teria feito por pequenos e localizados grupos compostos de famílias unidas por um interesse comum. Temos nessa passagem uma associação estreita entre phyla e a organização do laós e a constiuição a comunidade no seu sentido mais amplo, o povo.

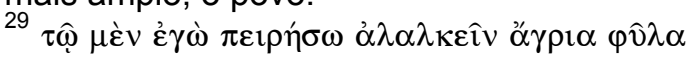


que ele poderia ir sossegado falar com Agamêmnon, pois ela mesma ficaria para cuidar do corpo de Pátroclo, afastando as moscas que viessem sobre ele. A deusa emprega a palavra phyla para denominar as moscas que viesse sobrevoar o corpo de Pátroclo.

Phyla é também utilizado para denominar o conjunto dos deuses ${ }^{30}$, das mulheres $^{31}$, dos gigantes ${ }^{32}$, dos aliados dos troianos ${ }^{33}$. O singular, phylon, é empregado com conotação um pouco diferente. Eumeu, o porqueiro, ao falar ao mendigo que abrigava em sua casa, na verdade Odisseu disfarçado, que os pretendentes prepararam uma emboscada para matar Telêmaco, diz que com isso eles pretendiam fazer desaparecer do solo de Ítaca o phylon de Arquésios, avô paterno de Odisseu ${ }^{34}$. Aqui phylon assume o significado de raça no sentido de descendência, de geração, de gênos ${ }^{35}$. Assim phyla, um plural, denota uma reunião concreta e delimitada de elementos , que compartilha de uma condição comum, enquanto phylon, um singular, envolve a idéia de geração, de raça, de descendência comum.

Particularmente interessante é a associação entre os vocábulos phyla e ethnéa que se opera no tema da mosca. Quando os aqueus estão avançando em direção a cidadela troiana, eles são comparados aos amontoados de moscas que sobrevoam pelo estábulo, ansiando o leite derramado nas vasilhas.

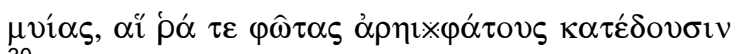

30 Ilíada 5.441; 15.54, 161, 177.

31 Ilíada 9.130, 272.

32 Odisséia 7.206.

33 Ilíada 17.220.

34 Odisséia 14.181.

35 Esse mesmo sentido, empregado em relação a Helena cf. Odisséia 14.68-9. Aos homens e aos deuses em geral cf. Ilíada.5.441-2. 
Eram como os numerosos grupos repletos de moscas que na primavera, quando o leite molha os vasos, voam pelo estábulo de ovelhas Assim numerosos, ante aos Troianos, os cabeludos aqueus estavam na planície desejando destruí-los ${ }^{36}$

"Como os muitos grupos ("ع $\theta v \varepsilon \alpha \pi \mathrm{o} \lambda \lambda \grave{\alpha})$ repletos de moscas pelo estábulo, quando da ordenha, assim os aqueus se espalhavam pela planície”, nos diz o épos. No símile, os amontoados de moscas são denominados de ethnéa. Éthnos também é utilizado para denominar um enxame de abelhas ${ }^{37}$, bandos de pássaros ${ }^{38}$, a infantaria dos aqueus ${ }^{39}$, os Lícios $^{40}$, os aqueus ${ }^{41}$, o laós ${ }^{42}$ e o grupo de companheiros ${ }^{43}$.

Éthnos define um grupo formado por seres que dividem a mesma condição, não importando qual ela seja: a condição de pássaro, abelhas, ou combatentes a pé. Segundo Chantreine, éthnos expressa a idéia de um grupo mais ou menos permanente de indivíduos, soldados e animais, daí a sua derivação para os conceitos de nação, classe e casta (Chantraine). No Bailly, encontra-se como seu significado primeiro: "toda classe de seres da mesma origem ou condição". Éthnos define um grupo que pertença a uma mesma categoria. É nesse sentido, no qual ethenéa se as-

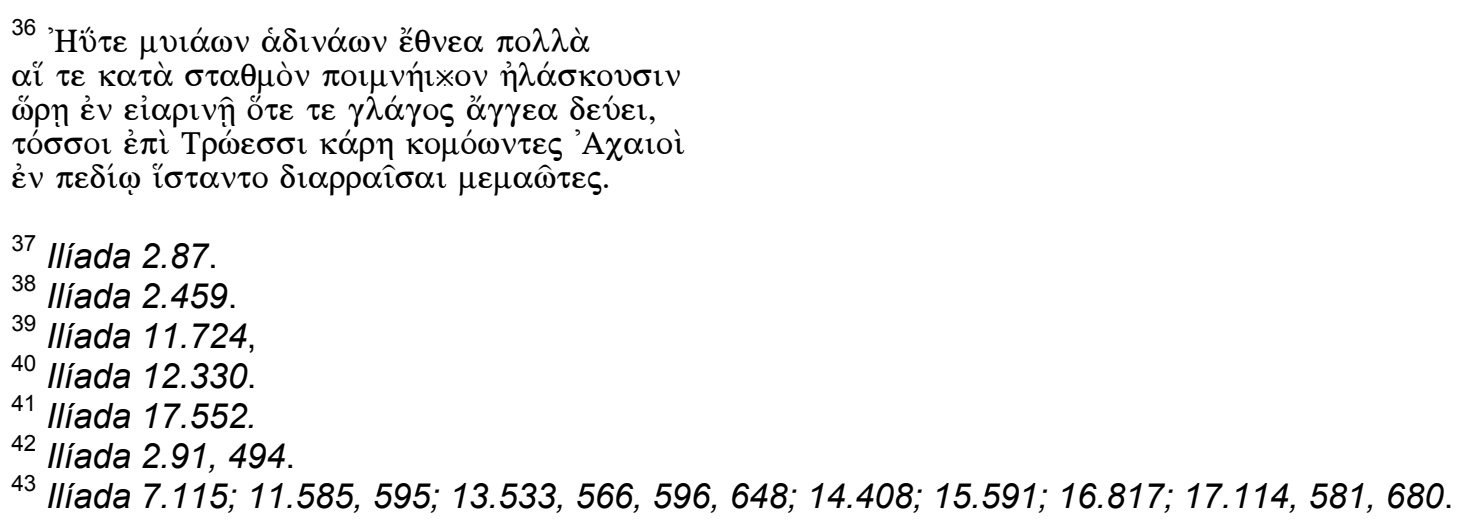


socia a idéia de phyla, que optamos por traduzir phyla por tribo, denotando uma reunião de elemento de indivíduos que compartilham uma identidade comum.

Voltemos agora a nossa questão inicial: qual seria a relação existente entre $p$ hrétre e phyla? Na fala de Nestor, ela aparece, do mesmo modo que phyla, como uma subdivisão de laós, porém que tipo de identidade ou condição gozariam os pertencentes de cada phretre e cada phyla?

Em Homero, comenta Andrews, o grupo não toma parte das batalhas. Embora seja descrito, serve apenas de pano de fundo para a ação dos heróis. Homero não estaria interessado nas táticas coletivas de combates, havendo no poema somente poucas passagens em que se preocupa com a organização do exército, que servem somente para criar um efeito particular em seu contexto imediato, e que depois são descartadas. Quando Agamêmnom, nos diz ele volta a falar com Nestor, após ter acatado o princípio organizador por phrétre e tribos (phyla), o próprio Nestor alude a um tipo de organização que não teria nada haver com a precedente ${ }^{44}$, dizendo a Agamêmnon para dispor os cavaleiros, os cavalos e os carros à frente, e a infantaria atrás, com os mais fracos e covardes no meio, para que assim fossem obrigados a lutar. Andrews observa que o conselho de Nestor sugerindo a Agamêmnon organizar a tropa (laós) por fratrias e por tribos seria também, como no caso da passagem do amante da guerra civil, uma intrusão isolada.

\footnotetext{
${ }^{44}$ Ilíada 4.292.
} 
Sua alusão a um esquema de organização da tropa, fundado nas relações de parentescos, que segundo ele caracterizaria a phrétre, seria motivada pelas peculiaridades do processo de composição da poesia oral, como vimos acima. Assim a tropa homérica não refletiria nem a organização das realezas micênicas, nem a sociedade aristocrática, cujo declínio marcaria o início da história grega conhecida, mas um momento intermediário: o período das migrações que, desagregador por natureza, teria favorecido o surgimento de grupos cuja coesão seria proporcionada pela capacidade dos chefes em liderar e motivar lealdades. Assim na sociedade homérica, como reflexo desse princípio de coesão, os grupos de combatentes caracterizarse-iam pela lealdade dos hetaîoiroi aos seus líderes e não pelas relações de parentescos. Desse modo conclui que, embora as relações de parentescos tenham um papel importante na épica, elas não se constituiriam em um princípio de organização nem da tropa, nem da vida civil, exceto nessas duas observações de Nestor, que segundo ele seriam intrusões isoladas, originadas em um período posterior ao da cristalização do material formular dos poemas, refletindo um período em que as relações de parentescos foram eclipsadas pela da lealdade dos hetairoi. Porém, ao que se refere à sua utilização na épica homérica, considera que há grandes dificuldades para a definição precisa dos tipos de relações sociais que ela encerraria. Qual seria o grau de parentescos que haveria entre os membros que a comporiam a fratria homérica? De que forma ela se distinguiria de seu modelo clássico? Ele mesmo responde que o texto não apresenta evidencias conclusivas para qualquer reposta definitiva.

Donlan coloca a questão de modo diferente. Segundo ele, a teoria tradicional considera que a sociedade grega foi sempre uma ordenação inclusiva de seguimen- 
tos de parentesco herdados dos dórios ou dos aqueus. O suporte para tal crença seria as palavras gênos, phrétre e phyla traduzidas, respectivamente, por família, clã

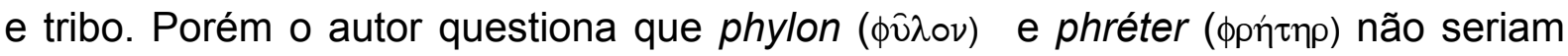

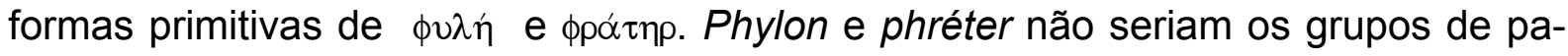
rentescos teorizados pelos estudiosos do século XIX, mas o nome dado aos seguidores de um chefe, unidades estruturais originadas na Idade das Trevas em resposta às condições geradas pela desagregação micênica ${ }^{45}$.

A "Dark Age”, segundo ele, caracterizar-se-ia por pequenas vilas não fortificadas constituídas de pequenas casas. Os assentamentos eram rústicos e espalhados, e os laços de sociabilidade girariam em torno de dois eixos: o parentesco e a vizinhança. A rede formada por casas e parentelas, espalhadas entre as aldeias isoladas, era fluída e amorfa, sendo as alianças pessoais o mecanismo estruturante dominante. Nesse período turbulento de migrações e reagrupamentos, a habilidade mais funcional seria a militar e a liderança. Os homens que excedessem nessas habilidades seriam os líderes guerreiros, em torno dos quais os outros gravitariam. Favorecidos por habilidades e circunstâncias, certos oîkos vieram a dominar os seus vizinhos e parentes, formando um tipo de política rudimentar e uma elite econômica entre as pequenas sociedades guerreiras.

\footnotetext{
${ }^{45}$ Interessante salientar a inversão que Dolan opera em relação ao raciocínio de Andrews. Donlan também considera que na "Dark Age", a época das migrações de Andrews, o tecido social não seria alinhavado a partir de relações de parentescos, mas nas de camaradagem. Porém, ao invés de considerar as duas passagens em que há a ocorrência do termo phréter fosse uma interpolação, pois essa palavra remeteria à relações de parentesco, o que estaria em contradição com o núcleo do poema, Donlan "modifica" o seu significado, considerando que ela não encerraria a idéia de relações de parentescos.
} 
Dadas as condições de vida nessa época, - população esparsa de pastores e sitiantes, habitando aldeias não fortificadas com nenhuma autoridade centralizada ou grupos corporativos de parentes - o estabelecimento de numerosos pequenos bandos independentes, centrado em torno de um líder, pareciam asseguradas. A tribo (phyla) denotaria os pequenos grupos locais. Minúsculas unidades sociais naturais, compostas de poucas famílias e ocupando uma área pequena. Não era uma corporação formal baseada na realeza, mas na identidade compartilhada de livres seguidores de um líder. O desenvolvimento da vida agrária sedentária teria sido a variável na transformação desses grupos sociais fluidos para comunidades mais coesas. Unificados por interesses corporativos e laços recíprocos, os membros de alianças separadas passaram a se olhar eles mesmos como irmãos. Nesse momento a palavra phréter teria sido cunhada para expressar o sentido dessa comunidade mais vasta.

A estrutura da phréter permaneceria elástica, enquanto os basileus poderosos competissem uns com os outros por mais seguidores, porém, quando esses perderam a capacidade de expandir, elas se estabilizaram, desenvolvendo uma estrutura interna e oficializando o culto religioso. A pertença a um grupo tornava-se assim hereditária, e a estrutura das tribos (phylas) foram absorvidas, sendo os laços pessoais substituídos pelos de parentescos. Segundo ele, a phráter, associação dos homens membros da união de famílias ou clãs, baseada no oikos primitivo, não teria expressão no texto homérico devido a solidariedade das phráteres ser de caráter local, envolvendo os parentes e vizinhos. Um lócus de integração eclipsado pelo maior nível de estruturação das alianças pessoais. 
As diferenças entre Andrews e Donlan são grandes. Segundo Andrews, phréter seria uma associação que envolveria relações de parentescos. Para Donlan, seria uma associação de caráter fluido que não se fundamentaria em relações de parentescos, aspecto esse que teria sido desenvolvido tardiamente. Para Donlan, a tribo seria a expressão do grupo local, enquanto a phréter, a unidade mais ampla. Para Andrews, seria exatamente o contrário: a phréter seria uma subdivisão da tribo.

Traduzir significa interpretar. Nesse sentido as divergências entre Andrews e Donlan são exemplares. Os dois balizam extremos opostos a que a interpretação pode levar ao se analisar essas duas passagens em que Nestor nos fala das esferas organizativas da sociedade homérica. A partir das leituras de Andrews e Dolan interpreta-se a observação de Nestor de forma distinta. Assim, para o primeiro, Nestor estaria aconselhando Agamêmnon a organizar a tropa de acordo com grupos que se constituiriam a partir de relações de parentesco, sendo a phrétre uma subdivisão de phylon. Para Dolan, por sua vez, Nestor estaria aconselhando a organização da tropa em grupos que não se constituiriam a partir de relações de parentescos, mas de lealdades livremente estabelecidas entre chefes e subordinados, sendo a phréter a unidade mais ampla. Assim nossa opção por traduzir phréter por fratria deve ser tomada com cautela para que ela não exerça função explicativa infundada. Os contextos sociais associados a ela não aparecem de forma definida a ponto de permitir precisar seus conteúdos sociais. A fratria homérica seria uma associação cujos membros manteriam relações de parentesco ou uma associação livremente fundada no princípio de lealdade a um chefe? Qual seria a pertinência da inversão operada por Donlan ao considerar a tribo homérica como o grupo local e a fratria como a unidade mais ampla? Os poemas não parecem fornecer informações a respeito, apre- 
sentando apenas indícios que podem levar ora a uma direção ora a outra. Prática que nos lembra Procrusto, que, para ajustar perfeitamente o tamanho dos corpos de suas vítimas à cama em que eram amarradas, ora esticava seus corpos ora cortava suas pernas. Os argumentos operados tanto por Andrews como por Donlan não são passíveis de verificação. Eles são externos ao poema e não são atestados por nenhuma outra fonte. Trata-se de exercícios lógicos que buscam lançar luzes sobre realidades que a própria narrativa não desvela. Não podemos optar por nenhum deles. Lembrando Sísifo, cada um tem a sua própria rocha, e esforço algum seria capaz de manter qualquer uma dessas interpretações no topo da montanha, sem que rolem abaixo, vítimas do peso dos próprios argumentos. Mas, de certa forma, essa é a condição de todos que se dedicam às questões da "sociedade homérica". Todos, incorremos em hybris (desmedida), encerramos algo de Sísifo e de Procrusto, de tal maneira que o melhor a fazer é não dar tanta importância à pedra em si (nessa metáfora, as conclusões), mas à forma como se procura levá-la ao topo (nessa metáfora, os argumentos), pois o caminho revela o exercício hermenêutico, o esforço de interpretação. Esse muito mais enriquecedor do que as próprias conclusões, uma vez que põe o pensamento em contato com ambigüidades e contradições motivadas pelas indagações que se busca responder. Mas continuemos, pois ainda não chegamos ao topo.

Não podemos seguir na análise das palavras proferidas por Nestor, fixando significados precisos para phréter, pois o texto não a precisa. Porém, com toda segurança, pode-se considerá-la como um elemento organizativo da vida comunitária. Não possuir lar nem phréter é algo imaginável somente aos amantes da guerra intestina no interior da própria comunidade, o dêmos, para alguém que viva à margem 
dos laços de sociabilidade que constituem a vida em grupo, ou seja, para alguém sem regra e sem lei.

"Sem lar, sem fratria e sem lei". As palavras de Nestor destituem os amantes da cruenta guerra civil de qualquer traço de sociabilidade. Negam-Ihe a participação nas esferas de organização da vida coletiva. Se se invertesse os termos apresentados pelos versos, transformando em negativo o que é positivo e vice-versa, obter-se-ía uma formulação que torna mais claro os pontos que se pretende evidenciar. Como resultado dessa operação, ter-se-ia: "aqueles que agem de acordo com a regra/lei, constituindo lar e fratria são os que não desejam a guerra que se abate sobre o povo (dêmos)", pois estando integrados na organização do povo (dêmos), fazendo parte dele, o sofrimento imposto ao dêmos recairia sobre eles mesmos. A fala de Nestor evidencia a concepção de que, para alguém chegar a ponto de desejar a guerra civil desagregadora, deve-se estar à margem da comunidade formada pelo povo

A aproximação temática entre elementos da llíada e da Odisséia é sempre controversa, mas nesse caso parece bem plausível. "O amante da guerra civil" da fala de Nestor e a narrativa de Polifemo compartilham de um mesmo núcleo temático: o da ausência de laços de sociabilidade. No caso de Nestor, o guerreiro insociável é taxado com duas palavras - aphrétor (sem fratria) e anêstios (sem lar) - cujos contextos não permitem a clara compreensão do que significariam. No caso de Polifemo, também taxado de iníquo/sem regras (athêmistos), essas duas palavras não aparecem. No lugar delas encontra-se a descrição de duas situações: ele vive só e não mantém contato com os outros. Assim o amante da guerra civil, sem lar e sem phréter de Nestor possui estreita relação com Polifemo sem família, que não man- 
tém contato com os outros: ambos são selvagens que não constituem os laços de sociabilidade que caracterizam o humano.

No mundo fantástico, percorrido por Odisseu, vivendo sozinhas, temos ainda : Calipso e Circe. Como Polifemo, Calipso também vive em uma gruta. Por motivo adverso ao dele também é um dos empecilhos para que Odisseu retornasse à sua casa, pois queria torná-lo imortal e transformá-lo e em seu companheiro. Foi em sua ilha que, na maior parte do tempo, Odisseu se vê retido. Circe habita uma choupana e, como Calipso, também é uma ameaça a volta de Odisseu. Não por querer transformá-lo em um deus, mas em um animal. Temos aqui um caso interessante. As duas ameaçam o retorno de Odisseu: uma alçando-Ihe a esfera da divindade, a outra, a da animalidade. O modo de vida de Polifemo possui simetria com o delas. Os três vivem sós, dispensando laços de solidariedade comunitária, embora mantenham contatos esporádicos com seus iguais. Nesse mundo fantástico, tanto a deusa, como a feiticeira e Polifemo parecem definir os limites que separam o humano e o não humano: eles vivem sós ${ }^{46}$, condição de vida que, para Aristóteles, só é possível aos deuses ou animais ${ }^{47}$.

${ }^{46}$ Ilíada 9.63-4.

O tema da vida apartada dos laços de solidariedade comunitária também aparece na llíada. Nestor em uma de suas intervenções observa que aquele que ama a guerra civil flagelante é iníquo (athe-

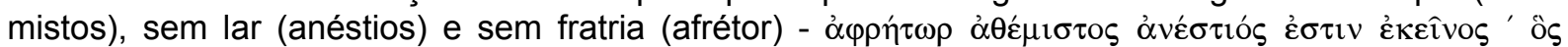

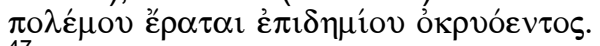

${ }^{47}$ Pol.1253a. 
Embora Odisseu mantenha contato somente com Polifemo, na ilha havia outros Ciclopes, a respeito dos quais se apresenta descrição detalhada de seus modos de vida. Eles também são qualificados de iníquos (9.106), mas não vivem solitários como Polifemo. São descritos como um povo que se organiza na esfera familiar, porém

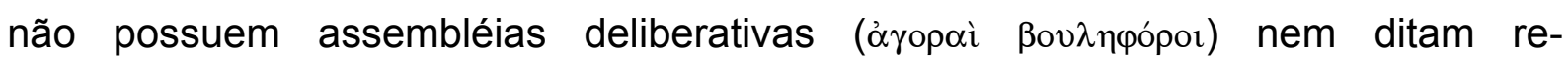
gras/sentenças entre si $(\theta \varepsilon \dot{\mu} \mu \iota \tau \varepsilon \varsigma)$. Entre os Ciclopes cada um dita as regras para

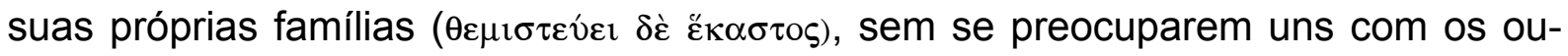

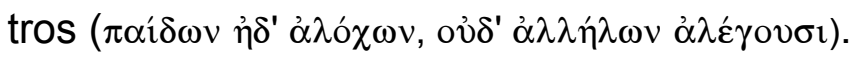

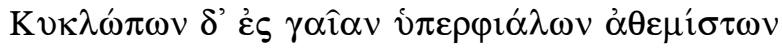

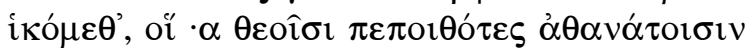

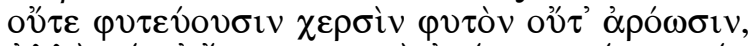

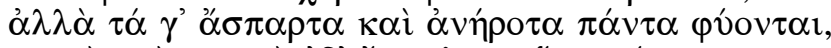

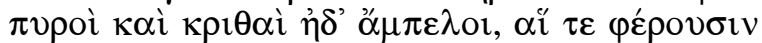

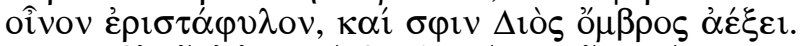

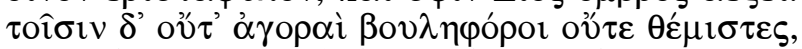

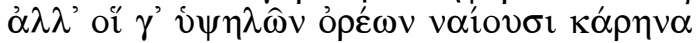

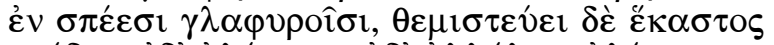

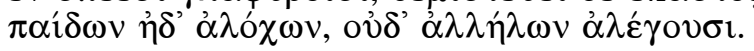

(versos 106-7)Chegámos à terra dos Ciclopes, (106) esses gigantes sem leis, que se fiam nos deuses imortais e não fazem com seus braços qualquer plantação, qualquer lavoura; lá, tudo nasce sem que a terra tenha recebido semente ou amanho: o frumento, a cevada e as vinhas que dão o vinho dos pesados cachos, inchados para eles pela chuva de Zeus. (112) Não têm assembléias deliberantes nem leis; habitam nos cumes das montanhas em antros côncavos, (versos 114-6) e cada qual impõe a lei a seus filhos e suas mulheres, sem cuidar dos outros. ${ }^{48}$

${ }^{48}$ Odisséia 9.106-16. 
Os ciclopes não se reúnem em assembléias, nem ditam regras entre eles, fundando assim um espaço coletivo. Porém, não são apresentados como seres solitários, que vivem sozinhos como Polifemo. Eles se organizam na esfera familiar, com cada um impondo as leis/regras para seus filhos e esposas.

O verbo traduzido aqui por "impor leis" é themistéuo, que, literalmente, significa ditar as thêmistes (as leis/ as regras), o que motiva controvérsias, pois, se no verso 106, os Ciclopes são apresentados como athêmistos (sem lei/regras), e no verso 112, são caracterizados como um povo que não possuía assembléias e nem leis/regras (thêmistes), nos versos 114-5 são apresentados como um povo que ditava leis e regras somente na esfera familiar. Se eles ditavam leis/regras no âmbito familiar, porque são caracterizados de destituídos de leis/regras nos versos 106 e $112 ?$

O recurso de se lançar mão de outras passagens para analisar a utilização do verbo themistéuo (ditar thêmistes) não nos é de grande ajuda aqui. Na épica, além dessa passagem, ele se apresenta somente em mais outra. Trata-se do verso llíada.11.569, que se refere a Minos, no Hades, distribuindo a justiça (themistéuo) entre os mortos. Seriam as thêmistes ditadas pelos Ciclopes à suas famílias de natureza inferior às de Minos, e às que se pronunciavam nas assembléias, justificando assim a grave condenação de serem "athêmistos arrogantes", que se thes apresenta na narrativa.

No livro III das Leis, Platão cita essa passagem da Odisséia. Nele, os Ciclopes são apresentados como exemplo da organização social de um dos estágios do lento aparecimento da sociedade política, no seio de uma comunidade. Procurando identi- 
ficar qual teria sido a origem do governo das cidades, o interlocutor, apresentado simplesmente como "o ateniense", desenvolve um raciocínio que parte de uma situação em que os homens vivem sem a necessidade de leis e governos até chegar ao momento em que as leis aparecem. Para criar o marco, a partir do qual inicia o seu raciocínio, alude que, por vezes sem conta, os homens já teriam sido destruídos por inundações, doenças e outras causas, salvando-se apenas uma parte mínima do gênero humano. Então ele se fixa na ocorrência de uma dessas catástrofes: o dilúvio.

Segundo o ateniense, os que tivessem escapado à destruição viveriam mais ou menos como os pastores das montanhas, em cujos cumes se conservaria a tênue centelha do gênero humano. Tendo desaparecido as artes, o conhecimento acumulado e os instrumentos da vida civilizada, o mundo dessa época seria um imenso e apavorante deserto, só com terras a perder de vista e com poucos rebanhos de bois e cabras restantes.

As condições que se impunham a eles levava-os ao isolamento, pela dificuldade de comunicações e pela escassa população. A princípio, diz ele, os homens se amavam e se viam com bons olhos. Não precisavam lutar para adquirir alimento. Não Ihes faltavam pastagens, havendo abundância de leite e carne. Dispunham de roupas em quantidade, casas e vasos. Não havendo pobreza nem riqueza entre eles, seus costumes seriam nobres porque nem a violência, nem a inveja e nem o crime encontrariam condições para germinar. Dessa maneira, seriam virtuosos. Então, ao descrever a constituição política que ordenaria os homens dessa época, cita os Ciclopes como exemplo. Sua citação confere com o texto homérico 
Quer parecer-me que se dá o nome de patriarcado ao governo que ainda subsite em muitas regiões, tanto entre os Helenos como entre os Bárbaros. O próprio Homero nos conta que era assim a vida dos Ciclopes: leis desconhecem, bem como os concílios nas ágoras públicas. Vivem agrestes, somente nos cimos das altas montanhas, em grutas côncavas, tendo cada um sobre os filhos e a esposa plenos direitos, sem que dos demais o destino lhe importe ${ }^{49}$.

David Bouvier ( 2002, p.235-43) observa que, com esse comentário, Platão estaria considerando os Ciclopes como naturalmente sensatos, justos e virtuosos, promovendo uma inversão do papel que, na Odisséia, os caracteriza como uma negação radical dos valores do mundo civilizado.

Aristóteles, em sua argumentação a respeito da evolução das formas de associações que levaram à constituição da pólis, também cita os Ciclopes como exemplos. Segundo seu comentário, a primeira associação natural entre os homens seria o oikos, composto pelo marido, a esposa, os filhos e os escravos. Em um esforço de exemplificar essa questão, nos fornece um exemplo feliz, dizendo que o oîkos seria formado por todos aqueles que comessem do mesmo pão ou na mesma mesa. A

${ }^{49}$ Leis 680b. Trad. Carlos Alberto Nunes.

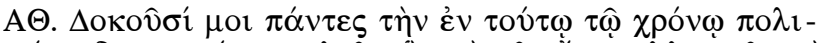

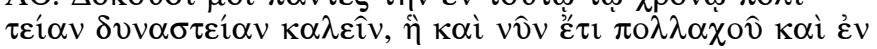

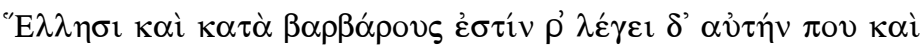

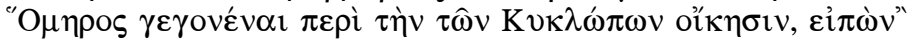

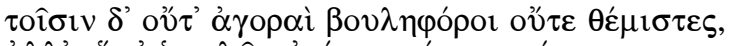

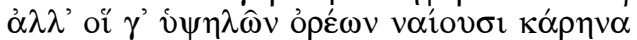

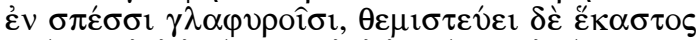

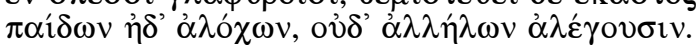


kome seria uma comunidade composta de vários oîkos, uma espécie de colônia deles. Novamente em um exemplo feliz, ele observa que a kome seria constituída pelos que compartilhassem do mesmo leite: os filhos e os netos. A pólis seria uma associação de várias kome. Aristóteles comenta que, no princípio, algumas pólis eram governadas por um basileu, pois que se reuniram a partir dos que eram governados por um, já que todo oîkos, como as kome, estaria sob o poder real do mais velho. Então, como um sinal de apoio e confirmação de sua opinião, cita os Ciclopes de Homero

É isto que Homero diz: "cada um dita a lei aos filhos e esposas", pois eles vivem dispersos (assim se vivia antigamente) ${ }^{50}$.

Comentando essa passagem, David Bouvier (Ibdim, 243-5) novamente expressa sua exclamação: Aristóteles não estaria consciente de que o modelo que invoca não é nada mais nada menos que o de Polifemo, os Ciclopes sem lei nem fé?! Para Bouvier, os paralelos que Platão e Aristóteles traçam com a epopéia basear-se-iam em um exemplo contraditório com os próprios objetivos de suas argumentações.

Chama-se a atenção para dois aspectos envolvendo a questão trazida por Bouvier. Um deles é o que ele mesmo evidencia, ou seja, se a utilização dos Ciclopes, como exemplos, seria contraditória ou não com os objetivos das próprias argumentações de Platão e Aristóteles. A resposta envolve debruçar-se sobre problemas

${ }^{50}$ Pol.1252b. Trad. Mário da Gama Kury. 
de interpretação que passam muito longe das preocupações deste trabalho. Primeiro, envolveria discernir quais seriam os objetivos de Platão e a Aristóteles e depois averiguar qual seria a fonte de que se teriam utilizado para citar os Ciclopes. Eles teriam tomado da narrativa da própria Odisséia como a conhecemos hoje?

O outro aspecto, que a discussão trazida por Bouvier nos coloca, é o da possibilidade de utilizar o seu argumento no sentido contrário. Ao invés de pensar a utilização que Platão e Aristóteles fazem da narrativa dos Ciclopes, em termos de contradição com o do texto épico, podemos pensar se o texto épico seria contraditório em relação ao que Platão e Aristóteles apresentam, ou seja, a conclusão de Bouvier de que os Ciclopes formariam um povo sem lei nem fé seria inequívoca?

Em que medida os Ciclopes apresentar-se-iam como um povo sem lei e nem fé na Odisséia? O verso 106 que os qualifica como athêmistes (sem regra/lei) teria relação direta com o verso 112, que os apresenta como um povo que não delibera em assembléias e nem ditam themistes entre si? E como relacioná-lo ao 115 e 116, que informam que, entre eles, cada um ditava as regras/leis em sua própria casa?

Segundo Mondi, o episódio possuiria inconsistências. Os Ciclopes seriam caracterizados com fatores idílicos e brutais incompatíveis entre si. O verso 106, que os descreve como arrogantes e iníquos e 107, que se refere a eles como confiantes nos deuses imortais, seriam contraditórios, não fazendo parte de um conjunto orgânico. Para ele, dificilmente o verso 106 poderia ter sido parte da descrição que se segue, pois é irreconciliável com a piedade que ela implica. Como seria possível harmonizar a existência utópica, proporcionada por Zeus, com o comportamento im- 
piedoso dos Ciclopes? Como poderiam ser arrogantes e athêmistes (sem leis/regras) e, ao mesmo tempo, bem aventurados pela graça de Zeus?

A solução desse problema encontrar-se-ia na relação que os versos $107-15$ manteria com o resto do episódio ${ }^{51}$. Mondi observa que não haveria nada de selvagem ou primitivo na caracterização dos Ciclopes. O mundo descrito neles seria a idealização de uma sociedade utópica pré-civilizada. Sua descrição não apresentaria qualquer condenação, embora no verso 112, como no 106, eles também apareçam

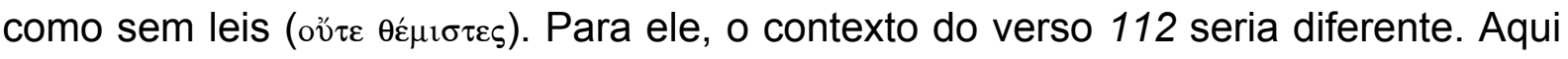
a ausência de thêmistes não conteria carga pejorativa, pois seria apenas a expressão de uma sociedade descrita em sua simplicidade inocente, vivendo na idade do ouro. Eram sem leis porque não precisavam delas. Diferente seria o caso do verso

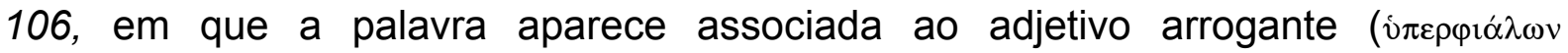
$\dot{\alpha} \theta \varepsilon \mu i \sigma \tau \omega v)$, que segundo ele daria uma conotação pejorativa e condenatória a expressão, já que arrogantes, sendo o epíteto por excelência dos pretendentes, promoveria uma associação estreita entre eles ${ }^{52}$.

Mondi desvincula athêmistes do verso 106, com oute athêmistes (sem leis) do verso 112. A justa posição seria o resultado de um amálgama de tradições ${ }^{53}$. A des-

\footnotetext{
${ }^{51}$ [os Ciclopes]se fiam nos deuses imortais e não fazem com seus braços qualquer plantação, qualquer lavoura; lá, tudo nasce sem que a terra tenha recebido semente ou amanho: o frumento, a cevada e as vinhas que dão o vinho dos pesados cachos, inchados para eles pela chuva de Zeus. Não têm assembléias deliberantes nem leis; habitam nos cumes das montanhas em antros côncavos, e cada qual impõe a lei a seus filhos e suas mulheres, sem cuidar dos outros.

52 Odisséia 1.134,227; 2.310; 3.315; 4.774, 790; 11.116; 13.373; 14.27; 15.12; 15.315; 15.376; 16.271; 17.481; 18.71; 18.167; 20.12; 20.291; 21.285,289; 23.356.
} 
crição dos Ciclopes, contida nos versos 107-15, pertenceria à tradição hesiódica em que eles aparecem como aliados de Zeus na luta contra os titãs, o que justificaria a bem-aventurança concedida pelo deus. Por sua vez, a caracterização dos Ciclopes como arrogantes no 106, seria o resultado da incorporação tardia do tema do "ogro", representado pela figura de Polifemo, tido como exemplo máximo de arrogância no mundo homérico.

A construção do episódio dos Ciclopes seria dessa forma o resultado da (com)fusão de duas tradições distintas: a dos Ciclopes hesiódicos, refletida na descrição de sua sociedade como idílica, e a narrativa "da fuga do monstro" refletida na caracterização de Polifemo. Os temas ter-se-iam reunidos com o propósito de se construir um episódio cuja principal função seria de, tendo como referência a prática da hospitalidade, caracterizar um comportamento que fosse considerado como exemplo máximo de desrespeito a essa regra. Assim, a caracterização dos Ciclopes, como arrogantes e iníquos, seria uma contaminação produzida pela incorporação do tema do "ogro", e a descrição que se segue uma expressão do material pertencente à tradição existente, antes da fusão dos dois temas. Tal fusão do material teria produzido um todo cujas partes seriam contraditórias entre si.

Para Mondi, a caracterização dos Ciclopes como selvagens seria motivada pela opinião corrente que os identifica a Polifemo, fazendo com que as características com as quais ele seja descrito também valham para todos os outros Ciclopes (assim 
o fazem Finley, Glotz e Benveniste). Para Mondi, os Ciclopes não praticariam a agricultura, a navegação, nem deliberariam em praça pública, porém não seriam nem selvagens nem iníquos. Tais adjetivos fariam parte somente dos qualificadores de Polifemo ${ }^{54}$.

Hernández (xxxx, p.) coloca a questão da presença de elementos contraditórios, no episódio, de maneira diferente. Nela, não haveria contradição entre a arrogância dos Ciclopes e a confiança que possuíam em Zeus, pois o verso 107 poderia ser lido simplesmente como um modo de enfatizar a bondade da natureza. Em um nível mais profundo, não expressaria, necessariamente, a visão objetiva do autor, mas antes a interpretação de Odisseu, diante da fertilidade da terra. A caracterização dos Ciclopes com aspectos idílicos e brutais não seria contraditória. A ciclopéia localizar-se-ia em um mundo antigo, que remeteria ao passado da raça humana, a idade do ouro. Nela, junto com Odisseu, reviveríamos a queda de Cronos, o início da soberania de Zeus e a divisão do mundo. Os Ciclopes seriam ambíguos como a Idade do Ouro, um tempo em que os homens vivam uma vida sem tormentos, mas que se encontrava sob a soberania de Cronos, um deus que devorava os próprios filhos. Não consideramos seu argumento convincente, mas sua opinião expressa um ponto

${ }^{54}$ Platão e Aristóteles também teriam operado essa separação? Teriam interpretado a sociedade ciclópica desconsiderando Polifemo? Se Aristóteles parece desconsiderá-lo, no caso dos Ciclopes, não deixa de lado a observação de Nestor, a respeito daqueles que amam a guerra civil. Ele observa que o homem é um animal político por natureza e que deve viver em sociedade. Aquele que por instinto, e não constrangido, deixa de participar de uma cidade seria um ser vil ou superior ao homem. Esse indivíduo, ele diz, seria segundo Homero merecedor da cruel censura de ser aphrétor, iníquo e sem lar, pois teria sede de combates e, como as aves rapinantes, não é capaz de se submeter a nehuma obediência. Aristóteles condena os que não constituem laços comunitários, os que não se associam. Será que ele desconhecia o exemplo de Polifemo. Teria ele se pautado no texto platônico e não na narrativa épica como a conhecemos hoje? 
de vista importante. Para ele, os Ciclopes não constituem uma sociedade simplória e paradisíaca, como também não são puramente selvagens e iníquos, mas constituem uma sociedade marcada pela ambigüidade em que o idílico e o brutal coexistem.

Em Kirk (1998), também se encontram, na caracterização dos Ciclopes, elementos que os qualifica como civilizados, juntamente com elementos que, segundo ele, denotariam aspectos não civilizados. Como elementos de civilização, aponta a confiança nos deuses imortais; o crescimento de grãos e vinhas, sem a necessidade de cultivo; o consumo de vinho; o fato de viverem próximos uns dos outros, em torno de Polifemo; de serem próximos aos deuses; e de cada um ditar as leis para sua própria família. Como elementos de não-civilização, elenca ao fato de seremi arrogantesí e iníquos (athêmistes); não possuírem assembléias; viverem isolad'ós em famíliaś nos topos das montanhas, sem se limportarem uns com os outros; nã́p possuíremin navios; e não prestarem respeito a żeus.

Sieu quadro de oposições é didático e muito nos facilita a discussão desses elemerítos, assim o reproduzimos, parcialmènte, abaixo:

\begin{tabular}{|c|c|}
\hline Elementos de Civilização & Elementos de não civilização \\
\hline 1)Confiantes nos deuses imortais & 1) arrogantes e iníquos \\
\hline 2)Cada família tem sua própria lei & $\begin{array}{l}\text { 2) Não possuem assembléias e } \\
\text { leis comuns }\end{array}$ \\
\hline $\begin{array}{l}\text { 3)Vivem em torno de Polifemo e } \\
\text { atendem ao seu pedido de socorro }\end{array}$ & $\begin{array}{l}\text { 3)vivem isolados no topo das } \\
\text { montanhas sem se preocuparem } \\
\text { uns com os outros }\end{array}$ \\
\hline
\end{tabular}

Os três termos polares, apontados nesse quadro, são fecundos quanto ao desdobramento da análise. Kirk classifica as características com as quais os Ciclo- 
pes são descritos em duas classes: características que referir-se-iam a elementos da vida civilizada e da não civilizada. Dos vários itens listados como elementos da vida civilizada, selecionamos três que dizem respeito diretamente à discussão que ora empreendemos. 1) confiança nos deuses imortais, 2) cada família dita sua própria regra e 3) os Ciclopes vivem nas proximidades de Polifemo e atendem seu pedido de socorro. A esses elementos de vida civilizada, ele associa outros três elementos que formariam com eles oposições polares, negando-os: à confiança nos deuses, opõe a arrogância e a iniquidade; à lei ditada em cada família, a ausência de assembléis e regras entre ele e à proximidade que mantinham entre si, a alusão de que viviam isolados no topo das montanhas.

Interessante como Kirk separa e classifica em classes distintas elementos que, no texto, são manifestações de uma mesma condição. Os Ciclopes vivem isolados no topo das montanhas e, assim sendo, cada um dita as regras para suas próprias famílias. Viver isolado no topo das montanhas e ditar regras cada um para sua família são contrapartidas de uma mesma condição. Tal ligação é percebida, por exemplo, nas análises de Glotz, Benveniste e Finley, que consideram-nos como selvagens ou primitivos, pois ligam esses três elementos: viver no topo das montanhas, isolamento e thêmistes ditada somente na esfera na familiar. Porém, no esquema explicativo de Kirk "ditar as regras no âmbito familiar" é tido como elemento de civilização, e a vida isolada nas montanhas, como elemento de "não civilização". Kirk os separa!

Ele assim o faz, visando enquadrar sua interpretação nos termos da sua análise estruturalista, buscando identificar termos polares que remeteriam à oposição cultura e natureza. No afã de encontrar a oposição polar, que se articularia com a 
ausência da agorá, Kirk busca uma presença que, diante de um aspecto negativo a ausência de assembléia - se colocaria de maneira positiva, no caso: a presença de organização familiar. Assim, o primeiro elemento, como aspecto negativo, seria uma marca do não civilizado (ausência de agorá), e o segundo o do civilizado (presença de organização familiar). Por sua vez, a vida isolada no topo das montanhas não é considerada causa ou conseqüência da organização familiar que apresentam. Ela é tomada como um novo termo polar que se associa a outro elemento, no caso, o deles viverem em torno de Polifemo a ponto de poderem atender o seu chamado de socorro.

A caracterização de Polifemo feita por Kirk também apresenta esse mesmo esquema, contendo elementos polares. Ele observa que Polifemo se comporta como um pastor diligente, até encontrar Odisseu em sua caverna, descrita como um recinto destinado às atividades de ordenha e criação de cabras e ovelhas, com esterco espalhado por todo lado. Dentro dela, há cestos cheios de queijos e redis repletos de cordeiros e cabritos. Tudo parece muito bem disposto para o trabalho. Os animais são distribuídos por idades: num lugar, as crias mais novas; noutro, as do meio; e num terceiro, as mais velhas. O leite ordenhado está disposto em vasilhas. O cenário é de uma economia pastoril. Sua morada indica que seus modos são rústicos. Para Kirk, Polifemo era vegetariano e não comia a carne de seu rebanho, posto que, em sua caverna, não há espetos para assá-las. Porém, após entrar em contato com Odisseu ,Polifemo adota um comportamento selvagem, comendo seus companheiros.

A caracterização de Polifemo envolveria assim características antagônicas, porém aqui, os termos polares inserir-se-iam em um patamar inferior de organização 
do que os apresentados para os Ciclopes, pois, enquanto esses se apresentam com elementos qualificados de civilizados ou não civilizados, Polifemo se apresenta com elementos qualificados de "relativamente civilizados" e super-não-civilizados. Como aspecto de relativa civilização, aponta a dedicação de Polifemo às suas ovelhas, o apelo que faz a Posídon e o fato dos outros viverem perto dele. Assim teríamos o seguinte quadro

\begin{tabular}{|l|l|}
\hline $\begin{array}{l}\text { Relativamente } \\
\text { Civilizado }\end{array}$ & $\begin{array}{l}\text { Super-não- } \\
\text { Civilizado }\end{array}$ \\
\hline Viver em proximidade com os outros & $\begin{array}{l}\text { Viver isolado, sem família e sem } \\
\text { senso de regra }\end{array}$ \\
\hline $\begin{array}{l}\text { Cuidar diligentemente de seu reba- } \\
\text { nho }\end{array}$ & \\
\hline
\end{tabular}

Em tudo isso, nos diz Kirk (1973, p.168), "há um tipo de confusão ordenada de atitudes sugerindo que os vários aspectos da natureza estão sendo manipulados proximamente com o propósito de avaliação". Segundo ele, os aspectos contraditórios da narrativa seriam muito sistemáticos para serem resultados da conflação proporcionada pela composição da poesia oral. Para ele, no curso do desenvolvimento do episódio, na sua forma odisseica, várias escolhas foram feitas por uma sucessão de cantores. Algumas delas seriam parcialmente determinadas pelo interesse no problema da relação natureza e cultura. Ao combinar elementos contraditórios, os poetas da tradição estariam dando expressão, conscientemente ou não, às ambigüidades e complexidades inerentes a conceitos como nomos e phisis; costume e natureza. Cultura e natureza teriam um caráter ambivalente, com ambas possuindo as- 
pectos benignos e selvagens. Tanto os Ciclopes, em geral, como Polifemo apresentariam esses aspectos dicotômicos.

As análises da sociedade ciclópica, selecionadas acima, expressam as três principais maneiras lógicas de se lidar com os elementos que se apresentam na narrativa. Glotz-Finley-Benveniste nivelam os Ciclopes e Polifemo. Suas leituras do episódio apresentam conclusões unívocas: os Ciclopes são selvagens e pronto, sendo a ausência de assembléia tomada como um dos principais pontos de apoio para suas opiniões. Desconsideram a presença de elementos antagônicos na narrativa, que possam exigir um tratamento mais aberto para as múltiplas possibilidades de interpretação. Tratam o texto como se apresentasse coerência e limpidez, tanto na utilização dos conceitos, como na forma em que se apresenta. Mondi, por sua vez, conclui pela presença de elementos contraditórios, separando os termos, opondo-os em antagonismo rígido. Em sua análise, o que é selvagem e civilizado aparecem justapostos, sem que seus elementos interajam, embora se confundam. Desse modo, pode concluir que os Ciclopes são apresentados como um povo que vive uma vida paradisíaca, enquanto Polifemo é um monstro impiedoso, selvagem e iníquo. Kirk utiliza um aparato conceitual mais elaborado para compreender o jogo de antagonismos, que acredita caracterizar a narrativa. Tanto os Ciclopes, como Polifemo, apresentariam aspectos de vida civilizada e de não civilizada. Para ele, a chave para a compreensão de como esse elementos interagiriam seria o conceito de ambivalência.

Um dos principais elementos textuais, que se deve levar em conta, no momento de avaliar sobre quais bases essas interpretações se sustentam, é a relação existente entre a sociedade ciclópica, descrita entre os versos 106 a 116 e a caracteriza- 
ção que se faz de Polifemo ${ }^{55}$. Em que medida eles se diferenciariam ou se identificariam? A questão não se encontra somente em considerar o episódio como um todo coerente, ou resultado de uma colcha de retalhos, proporcionada pela forma de composição oral. Benveniste e Hernandez, por exemplo, não separam Polifemo dos demais Ciclopes, porém concluem de forma diferente: selvagens, para o primeiro; quase divinos, para o segundo. No caso de Mondi e Kirk, ambos concordam que a narrativa contém elementos contraditórios e que ela teria sido composta a partir da confluência de dois temas distintos: o dos Ciclopes aliados de Zeus, e o do tema do monstro, que deve ser cegado para se fugir dele. Porém, Mondi separa os termos, identificando quem é o selvagem e quem é o paradisíaco. Kirk, não. Ele une os elementos, que estariam presente tanto entre os ciclopes como em Polifemo, remetendo às contradições que envolveriam natureza e cultura no âmbito da vida civilizada.

A fala de Polifemo a Odisseu, na qual ele expressa que os Ciclopes não se preocupam com Zeus, pois se consideram mais forte, é um bom exemplo dos problemas que as três propostas descritas acima implicam. Ela é impiedosa e coloca Polifemo e os demais Ciclopes no mesmo plano. Porém, na seqüência da narrativa, quando o monstro se encontra no interior de sua caverna, cego, gritando por auxílio, os outros Ciclopes, que foram até ele para prestar-Ihe ajuda, não parecem mostrarse impiedosos. Diante da fala de Polifemo, que Ihes informara que "ninguém o havia

${ }^{55}$ Confiantes nos deuses imortais, eles não plantam com suas mãos uma planta, nem aram; tudo nasce sem sementeira nem aração - trigo, cevada, vinhas que produzem vinho com grossas bagas e as chuvas de Zeus tudo fazem crescer. Não têm praças de assembléias, nem leis estabelecidas; moram na crista das altas montanhas, no seio de cavernas, e cada qual dita leis aos filhos e esposas, sem se preocuparem uns com os outros. 
ferido", eles, do lado de fora da caverna, Ihe respondem que se ninguém o havia ferido, então aquilo somente poderia ser uma doença de Zeus, e que ele deveria orar para seu pai, Posidon. A reposta demonstra espírito piedoso.

Em seu quadro, Kirk coloca a primeira situação como um aspecto não civilizado da caracterização dos Ciclopes, uma vez que se apresentam como impiedosos. Já a segunda passagem, ele classifica como "relativamente civilizada", exatamente pelo motivo contrário, por implicar piedade. Mondi, também observa essa contradição, porém, ela não seria resultado de uma visão de mundo que, conscientemente ou não, estaria refletindo sobre os aspectos ambivalentes da cultura e da natureza. Para ele, tais contradições resultam do projeto narrativo do poeta, que une em sua história dois temas distintos: o do ogro e o dos Ciclopes, sendo que se é perfeitamente possível distinguir o que é de um e o que é de outro. E, por último, para considerálos selvagens e não piedosos, teríamos que desconsiderar a passagem em que aludem a Zeus. Então, diante desse quadro, os Ciclopes seriam piedosos ou não? Deveríamos valorizar a fala de Polifemo, concluindo pelo comportamento impiedoso, ou a observação que fazem a Polifemo, concluindo pela piedade que apresentam? Ou concluir que o texto estaria refletindo uma forma de expressar os aspectos ambivalentes que caracterizariam a sociabilidade humana?

O texto apresenta elementos contraditórios, pelo menos para nossa sensibilidade moderna. Não é adequado fazer tábula rasa desses elementos. Eles não permitem uma leitura unívoca do episódio. Para considerá-los puramente selvagens ou idílicos, teríamos que fazer vista grossa para os aspectos que se opõem . Porém, levar em conta as contradições do episódio, por si só, não resolve a questão da in- 
terpretação, pois tudo depende da forma como entendemos e agrupamos os elementos contraditórios, que julgamos se apresentar na narrativa.

Nesse particular, gostaríamos de colocar a questão de um modo diferente, não com a finalidade de obtermos respostas mais válidas, pois todas são, mas com o propósito de organizar os elementos de forma distinta às apresentadas até aqui, expondo-Ihe assim facetas ainda não totalmente exploradas.

A discussão a respeito da natureza da sociedade ciclópica, visando definir de que forma a narrativa a identifica e classifica, é interessante somente no sentido que, por meio dela, manipulamos o texto de forma a aumentar nossa compreensão sobre ele. Considerá-la idílica, selvagem ou uma mistura ambígua, que envolva aspectos civilizados e selvagens, não constitui o objetivo de nossa reflexão. Tal empreitada significaria, voluntariamente, se submeter ao castigo de Sísifo. Os elementos antagônicos, presentes no episódio, pesam demais sobre os ombros dos que tentam construir explicações monolíticas e unívocas sobre o significado da ausência de assembléias entre os Ciclopes. A identificação mecânica entre a ausência de agorá e a manifestação de um estado selvagem somente pode ser empreendida se desconsiderarmos a passagem dos Lestrígones, a família de Eolo e as contradições presentes na narrativa dos Ciclopes. Para considerá-la idílica, teríamos de aceitar a cirurgia procrustiana que Mondi executa em sua análise, retalhando-o, ou aceitando os argumentos de Hernandez, que apela para o conceito de ambivalência, para justificar como uma sociedade, considerada por ele como idílica, pode conviver com aspectos brutais. Kirk expõe um modelo explicativo mais elaborado, porém seu jogo de oposições leva-o a criar um quadro complexo que, para ser aceito, necessita-se da anu- 
ência ao seu esquema analítico, que se baseia na idéia de que o episódio reflete o jogo de oposições existente entre natureza e cultura, no âmbito da vida civilizada.

Não vemos necessidade de optar por nenhuma dessas possibilidades, pois todas, ao seu modo, iluminam facetas de um texto que se apresenta complexo. E, para nós, essas interpretações já cumpriram a finalidade que objetivávamos ao analisá-las: mapear os elementos textuais contidos no episódio, e colocar a nu as lentes de que dispomos para visualizá-los.

A não constituição de assembléias deliberativas entre os Ciclopes é colocada contra um pano de fundo maior. Eles também não praticam a agricultura, a navegação, e não constituem um núcleo urbano, pois moram no topo das altas montanhas, no interior de cavernas. ${ }^{56}$ Uma das características marcantes dessa descrição é a presença de negações que pontuam as ausências percebidas por Odisseu. Como afirmativo, apenas que moram em cavernas, o que também não deixa de ser uma negação, já que evidência a questão de não serem urbanos e habitarem em casas construídas pelo homem. O olhar de Odisseu capta-os, principalmente, pelo o que eles não são. Procura entre eles os mesmos sinais que conformam sua vida civiliza-

${ }^{56}$ Odisséia 9.106-15,125-29. 
da. Apreende-os pelas atividades econômicas que não praticam, pelo centro urbano que não construíram e pela organização que não possuem. A descrição que faz dos Ciclopes projeta um conjunto de elementos que caracterizam a vida em uma cidade, integrando atividades produtivas, aspectos da sociabilidade e da organização política na pólis. Sua visão articula elementos que hoje claramente definiríamos como econômicos, políticos, sociais e religiosos, formando um conjunto que define a ordem adequada das coisas.

É com esse mesmo olhar que Odisseu descreve a desabitada "ilha das cabras", localizada diante das terras dos Ciclopes. Nela que estaciona seus barcos, antes de dirigir-se, com uma pequena comitiva, à caverna de Polifemo. Segundo Stanford (1975), sua presença na narrativa serviria como um artifício poético. A ilha possuiria função importante na construção do episódio, servindo para que a maior parte da tropa pudesse ficar esperando, em segurança, fora do alcance do Ciclope, a volta de Odisseu ${ }^{57}$. Porém, Byre, indo além dos artifícios de composição, adverte: se "ilha das cabras" tivesse sua justificativa na necessária economia do texto, o mesmo raciocínio não poderia ser aplicado à sua forma e dimensão, pois o foco primário da descrição não seria os aspectos relevantes para o desenvolvimento da ação já que, ao invés de fornecer vividos detalhes dela, concentra-se no que ela não é: desabitada, não possui rebanhos e terras lavradas.

As posições de Stanford e Byre não são excludentes, mas complementares. A ilha serve de abrigo para os companheiros de Odisseu, como a descrição dos ele-

${ }^{57}$ Stanford, 1975 
mentos que a compõe também é explicitadora do olhar com o qual observa o mundo, refletindo suas crenças e as bases de referências em torno das quais organiza suas opiniões sobre os povos que encontra. Sobre a ilha, nos diz Odisseu

(1) Vivem cabras selvagens inumeráveis; não as afasta o trânsito de pessoas, nem penetram ali caçadores, habituados ao desconforto quando percorrem os cumes das montanhas. Não a ocupam rebanhos nem aradas; está o tempo todo vazia de gente, sem semeaduras nem lavra, criando cabras berrantes.(2) Não possuem os Ciclopes naus de rostros vermelhos, nem vivem ali carpinteiros que fabriquem barcos bem providos de bancos, para thes irem buscar todas as utilidades, aportando as cidades de outros povos, como é freqüente os homens cruzarem o mar em navios, visitando-se uns aos outros./ (3) Ela, com efeito, não é ruim; é capaz de produzir de tudo; existem ali ao longo da costa do mar cinzento, Campinas regadas e fofas; ali seriam perenes as videiras, plana a aradura e, nas safras, teriam colheitas abundantíssimas, tão pingues são as terras. Há um bom surgidouro na enseada, onde não é mister passar amarras, nem deitar fateixas, nem prender proízes; os mareante podem aportar e ficar quanto tempo seu coração solicitar, ou até soprarem as brisas. Num extremo da enseada, corre água límpida duma fonte ao pé de uma gruta(... $)^{58}$.

Podemos dividir o relato em três momentos. No momento (1), opera-se uma descrição que evidencia, principalmente, coisas que ela não possui: o tempo todo vazia de gente, nela não há nem rebanhos nem terra arada. Porém, no momento (3),

${ }^{58}$ Odisséia 116-144. 
somos informados de que ela não é ruim, já que sua terra fértil capacitar-lhe-ia produzir colheitas abundantes, e sua enseada abrigaria um belo porto. Odisseu olha para a ilha deserta e, diante de sua natureza pródiga, enxerga uma cidade com plantações, rebanhos, atividade náutica e comércio, projetando nela o que ela não é, e imaginando o que poderia vir ser: uma cidade tal como as que ele conhecia, e faziam parte de seu mundo.

O jogo de presenças e ausências, operado pelo épos, projeta as instituições e as práticas da vida civilizada. $\mathrm{Na}$ base dessa ordem, encontra-se a prática da agricultura. Pelo regime alimentar, o épos diferencia o homem do divino e do bestial. Polifemo, o Ciclope, é descrito como um ser monstruoso que não tinha aspecto de homem comedor de pão. Do ferimento de Afrodite, escorre icor e não sangue, pois a deusa não se alimenta de pão, vinho e carne, como os mortais, mas de néctar e ambrosia. E o que é o pão e o vinho senão uma obra da vida civilizada! Para obtê-los não é preciso arar a terra, semeá-la, colher seu fruto e depois trabalhá-lo, transformando o trigo em pão e a uva em vinho?

Os povos, que se apresentam como ameaça, ao retorno de Odisseu, são também os que não cultivam a terra. Quando Odisseu chega à terra dos Lotófagos, comedores de flores, escolhe alguns companheiros para averiguar que homens comiam pão naquelas terras ${ }^{59}$. Ao chegarem na terra dos Lestrígones, o mesmo procedimento se repete, porém descrito de forma expandida. Demonstrando cautela, Odisseu sobe ao pico de uma elevação e dela não divisa trabalhos de bois ou de gen-

${ }^{59}$ Odisséia 9.89. 
tes; então escolhe três homens, sendo um arauto, para averiguar que tipo de gente comia pão naquela terra ${ }^{60}$. Para identificar o tipo de gente que habitaria as terras em que chega, Odisseu procura por sinais da prática da agricultura, pelos campos cultivados, pelos ergas, pelos homens comedores de pão. A agricultura é um dos elementos principais que orientam o olhar de Odisseu, quando se encontra em terras desconhecidas. Sua ausência indica que ele se encontra em um local desabitado, ainda em estado selvagem, ou que seus moradores ou são deuses, já que se alimentam de ambrosia e néctar, ou pertencem à esfera da bestialidade. Odisseu faz parte de um mundo de "homens comedores de pão" e "bebedores de vinho"61. Conseqüência da partilha que definiu o estatuto de homens e deuses, seu mundo é produzido pelo trabalho.

No ambiente das errâncias de Odisseu, o épos também se atém nos laços sociais presentes entre os povos visitados por ele. O episódio evidencia três modos de conduta social: a vida solitária, apartada do convívio social, marcando a ausência de laços associativos; os laços associativos familiares; e a organização comunitária, marcada pela constituição de um espaço coletivo que transcende a esfera familiar.

Se a sociedade ciclópica, tal como se apresenta na Odisséia, é selvagem, idílica ou ambivalente depende da forma como o interprete contemporâneo harmoniza

\footnotetext{
${ }^{60}$ Odisséia 10.98-103.

${ }^{61}$ Para passagens em que pão, vinho e carne aparecem como alimentos ver: Ilíada5.341; 8.507, 547; 9.216, 706; 11.89; 19.44, 161, 163, 306. Odisséia 1.139, 147; 3.479; 4.55, 60, 623, 746, 788; 5.99, $165 ; 7.175,265,295 ; 8.222 ; 9.9,87,89,191 ; 10.58,101,371 ; 12.19,327 ; 13.69,244 ; 14.46,449$, $455 ; 15.138,334 ; 16.51,83,110 ; 17.94,259,335,558,412,418,457,530 ; 18.360 ; 19.61 ; 20.137$, 254, 378; 22.21; 24.489
} 
os elementos contraditórios que a narrativa contém. Porém, para além desse julgamento, permeando a trama, mesmo que amalgamados de maneira que nos surge contraditória, o episódio dos Ciclopes põe em relação três elementos essenciais com os quais Odisseu configura os laços de sociabilidade de todas as gentes com quais trava contato em sua viagem: a vida solitária, a família e a comunidade. O olhar de Odisseu capta os Ciclopes pelas lentes das práticas que caracterizam a vida civilizada, consubstanciada na pólis: os laços associativos que a constitui, o espaço público que encerra, seus elementos arquitetônicos, como também suas atividades econômicas e sociais. Não seria essa também a perspectiva de Nestor na llíada ao dizer que aqueles que amam a guerra civil são iníquos, sem fratria e sem família? 


\section{Os Feácios e os modos de vida civilizada}

Dentre os povos que Odisseu visita, os Feácios se apresentam como paradigma da vida civilizada, tendo na agorá um espaço privilegiado de interação social. Odisseu chega à ilha, que eles habitam, em um local afastado da cidade, situado à praia, junto à foz de um rio ${ }^{62}$. Lá, encontra Nausícaa, a filha do rei, com suas servidoras, lavando as roupas de seus pais e irmãos. $\mathrm{Nu}$, cansado e faminto pede ajuda, no que é atendido.

Nausícaa expressa atitude piedosa, dizendo que, tanto aos bons como aos maus, é Zeus quem dispensa a sorte pelo mundo, portanto, Odisseu deveria suportar o seu fado; porém, entre os Feácios, receberia as atenções que se devem prestar a um suplicante.

Forasteiro, não me parece um homem ruim (kakós) nem louco. É o próprio Zeus quem dispensa a sorte no mundo aos bons e aos maus, a cada um como lhe apraz; naturalmente ele te destinou esse fadário e, queiras ou não queiras, tens de suportá-lo. No entanto, já que vieste parar em nossa cidade e nosso pais, não te faltarão roupas, nem outras atenções devidas a um suplicante que se nos depara pelo caminnho. Mostrar-te-ei o rumo da cidade (asty) e direi o nome do povo (laoi). São os feácios os habitantes da cidade (polis) e do país (gaia); eu sou a filha do magnânimo Alcínoo, em cujas mãos estão o poder (kratos) e a força (bie) dos feácios. ${ }^{63}$

${ }^{62}$ Odisséia 6.40.

${ }^{63}$ Odisséia 6.187-197. 
Nausícaa diz a Odisseu que os homens ( $\left.\lambda \alpha o_{\text {r }}\right)$ que habitam aquelas terras, e a sua cidade, eram os Feácios. Seu pai, Alcínoo, era quem detinha o poder (kratos) e a força (bie) entre eles. Ele reinava $(\dot{\alpha} \nu \alpha \delta \sigma \sigma \omega)^{64}$ sobre todos $(\alpha \dot{\alpha} \nu \theta \rho \omega \pi \circ \varsigma)^{65}$, e o povo $(\delta \hat{\eta} \mu \varsigma)$ o ouvia como a um deus ${ }^{66}$.

A cidade dos Feácios fora fundada por Nausítoo, que construiu casas (oǐkovs)e

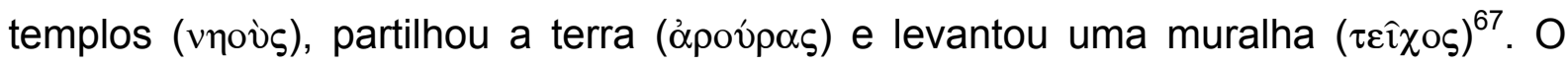
conjunto arquitetônico que compõe a cidade é descrito de forma a lhe conferir um caráter portentoso. A muralha envolve toda cidade. À sua entrada, há um porto em cada lado dela, separados por um istmo estreito. Os barcos ficam estacionados à seco, ao longo do caminho, e cada qual possui o seu galpão. A agorá situa-se próxima aos portos. Ela é lajeada com blocos de pedras e possui grande quantidade de bancos. Ao centro, há um templo a Posídon. Ela é um local destinado a diversos tipos de atividades. Nela se realizam os trabalhos de manutenção dos barcos. Nela Odisseu foi apresentado aos feácios, como também foram organizados os jogos em sua homenagem.

Do casario que compõe a cidade, apenas o solar de Alcínoo é descrito. Sua casa é dita ser a mais bem construída ${ }^{68}$. A porta de entrada de seu palácio era de

\footnotetext{
${ }^{64}$ Ánasso e um verbo cuja tradução para o português envolve dificuldades. Ele se relaciona ao vocábulo ánax. Segundo Benveniste, os dois nomes para a designação de rei em grego escapam às possibilidades de análise etimológica. Ambos foram reconhecidos nos tabletes micênicos - qua·si-reu e wá'na'ka. No contexto micênico o basileus é apenas um chefe local e não aparenta estar dotado de qualquer autoridade política. Por sua vez, o wánaks é considerado detentor do poder real.

${ }^{65}$ Odisséia 7, 23.

${ }^{66}$ Odisséia 7, 11.

${ }^{67}$ Odisséia 6, 9-10.

${ }^{68}$ Odisséia 6.301-2.
} 
ouro, com alizares e padieira de prata . A soleira era de bronze. As duas paredes, que se elevavam à direita e à esquerda da porta, do limiar até ao fundo, possuíam cornija de esmalte azul. No interior da grande sala, à direita e à esquerda, havia assentos adornados com finos xáreis de tecido fino, apoiados contra as paredes. Jovens mancebos, esculpidos em ouro, portavam tochas acessas ${ }^{69}$.

Ao que se refere à prática da agricultura, o épos descreve o pomar localizado ao lado do pátio de entrada da casa de Alcínoo, fazendo parte do conjunto de seu solar. Nele havia pereiras, romanzeiras, macieiras, figueiras e oliveiras e um fértil vinhedo, com uma horta ao fundo, como também duas nascentes, nas quais as pessoas da cidade iam buscar água ${ }^{70}$. Para além dos muros da cidade havia um bosque consagrado à Atena ${ }^{71}$, campos selvagens e terras cultivadas ${ }^{72}$. Fora dos muros da cidade também se localizava o têmenos de Alcínoo $^{73}$.

\footnotetext{
${ }^{69}$ Muito tem se dito que a riqueza, com que os palácios são descritos na épica Homérica, não teria contrapartida histórica. Seriam resultados dos exageros proporcionados pela poesia oral. Segundo, por exemplo, Redfield seria um artifício poético com a finalidade de criar o efeito poético da "distância épica", uma forma de criar a impressão de que a narrativa se passaria em tempos passados, em que os feitos humanos transcendiam em magnitude às obras dos realizadas no presente. A ferramenta da distância épica teria por finalidade criar um ambiente narrativo qualitativamente diferente, no qual os homens do passado eram tidos como mais fortes, mais nobres e mais ricos. Porém, consideramos que tais possibilidades não sejam uma objeção para utilizarmos a descrição da casa de Alcínoo em nossa análise. No fundo não é de importância alguma se o que é descrito sobre a casa dele teria contrapartida na experiência histórica ou não, pois, ficção ou não, O mundo feácio possibilita-nos perceber, nos elementos que são selecionados para descrevê-lo, as formas sociais, políticas, econômicas sobre as quais Homero projeta sua "utopia". Assim na descrição que se faz do palácio de Alcínoo, podemos encontrar os elementos que constituem, na visão homérica, os itens que devem constituir a casa de um rei, a sua organização, como também sua posição de destaque perante as outras casas.

${ }^{70}$ Odisséia 7.81-102.

${ }^{71}$ Odisséia 6.293.

${ }^{72}$ Odisséia 6.259.

${ }^{73}$ Odisséia 6.293.
} 
A narrativa dos Feácios insere-se em um contexto de vida civilizada. Praticam a agricultura. Cultuam os deuses. Vivem em casas no interior de uma cidade murada e praticam a navegação. Estabelecem relações sociais que transcendem a esfera do oikos. Diferentemente dos Ciclopes, os Feácios se organizam em um espaço coletivo consubstanciado na figura de um rei e da uma assembléia. O paralelismo, no jogo de correspondência dos elementos que se encontram entre os Feácios e que estão ausentes nos Ciclopes, é claro. Diferenciam-se em todos os aspectos em que são caracterizados. No tocante ao ambiente construído e às práticas econômicas, para cada item presente na vida dos Feácios há uma explicitação clara da ausência desse elemento entre os Ciclopes e Polifemo

\begin{tabular}{|l|l|}
\hline Ambiente construído e práticas econômicas \\
\hline Feácios & Ciclopes \\
\hline Pólis murada & Nada \\
Constroem \\
\hline Templos & Vivem em cavernas \\
\hline Casas & Não possuem barcos \\
\hline Porto & Não aram \\
\hline Terras lavradias & Não Possuem agorá \\
\hline Agorá & Não possuem rei ? \\
\hline Rei
\end{tabular}

Originalmente, os Feácios habitavam a mesma região dos Ciclopes, a Hipéria, mas como esses eram vizinhos muito incômodos, resolveram ir embora, habitar outro lugar, a ilha de Esquéria ${ }^{74}$. Como os Ciclopes, eles também descendiam de Po-

74 Jenny Strauss Clay (1980) considera que a "ilha das cabras" seria Hipéria, a antiga morada dos Feácios. Para ela, a chave para a correta compreensão do episódio estaria no significado do verbo 
sidon. Thalmann (1984) observa que a fixação de antepassados comuns e de vizinhanças geográficas serve para chamar a atenção para oposições polares, que caracterizaria o que ele chama de "modo básico de expressão da poesia oral". A épica homérica refletiria uma visão de mundo que é uniforme, não somente em seu conteúdo, mas também em sua forma estrutural cujos princípios básicos seriam a similaridade e a antítese. A base dessa maneira de ver as coisas seria uma concepção da forma como "enclousure", no qual extremos antitéticos definiriam os limites do mundo conhecido, constituído de partes simétricas justaposta. O modo básico desse tipo de poesia seria a criação de oposições simétricas. Assim, Feácios e Ciclopes, juntos, marcariam os extremos da selvageria e da civilização. Um definir-se-ia pelo outro e, nos extremos, contrabalançar-se-iam. Segundo ele, tal forma de ver o mundo derivaria de um certo modo de pensar que seria característico do período geométrico e arcaico. Além da arte, a única evidência desse tipo de pensamento seria o hexâmetro homérico.

Para Vidal-Naquet, lembrando Levis-Strauss, os ciclopes são para os feácios o que o cru é para o cozido. A justaposição desses dois povos, no âmbito da narrativa, serviria para explicitar uma das principais noções do ideário grego sobre a organização da vida e da constituição da experiência humana: a concepção da condição hu-

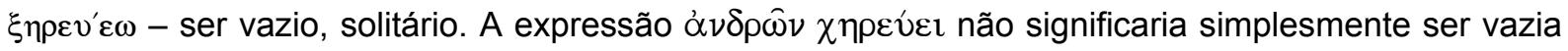
de homens, deserta, pois tal sentido seria melhor coberto por $\xi \eta^{\prime} \tau \varepsilon \iota \lambda \alpha \omega \hat{\omega} v$, mas enviuvada ou privada de homens. Partindo do princípio de que ninguém pode ser privado do que não teve, ela conclui que o verbo implica que o sujeito está ou foi privado de algo, o que indicaria que a ilha anteriormente já teria sido ocupada. Seus antigos ocupantes seriam os Feácios. Bremmer critica Clay afirmando simplesmente que xhreu/ew pode ter sido utilizado metaforicamente, e que nada na descrição sugere que a ilha já tivesse sido ocupada. 
mana marcada pela exclusão da condição divina e pela inclusão em uma ordem que o distingue da vida animal, marcando assim uma oposição entre a vida civilizada e a vida selvagem. Segundo ele, essa forma de pensar estaria presente em toda a experiência grega, o que mudaria seria apenas os seus conteúdos. Em Homero, a oposição entre a vida civilizada e a vida selvagem seria a do campo cultivado e a do campo selvagem. Uma pólis (um ponto fortificado), um dêmos (um pequeno grupo humano), campos trabalhados, cozimento do alimento, prática de sacrifício e a ausência do canibalismo e do incesto seriam signos de civilização, que formariam um conjunto cujos termos seriam indissociáveis.

Clay (Ibid. p.132) enquadra o jogo de oposições entre Feácios e Ciclopes de maneira diferente. Para ela, as conexões entre eles iriam além da simples oposição entre barbárie e civilização, ou natureza e cultura. Tanto os Feácios como os Ciclopes estariam de fato próximos aos deuses. Na Odisséia, o humano definir-se-ia em oposição ao super-humano, representado pelos Feácios, e ao sub-humano, representado pelos Ciclopes. Odisseu, nesse sentido mostraria ser ele mesmo não somente o melhor dos aqueus, mas encerraria as melhores possibilidades do homem em sua precária posição entre os deuses e as feras. Hartog (2004, p.35) observa que o espaço das errâncias de Odisseu apresenta-se como não cultivado e desprovido de sociabilidade. Atravessá-lo significa percorrer os gêneros de vida e inventariar os regimes alimentares, até as formas extremas da antropofagia. Nesse espaço, ninguém tem relações com que quer que seja. Calipso e Circe vivem sozinhas. Eolo vive fechado em sua ilha com sua família. Os lestrigões são canibais e não hospitaleiros. Em suas viagens, nos diz ele, Odisseu realiza "a experiência da alteridade 
radical, pelo questionamento das fronteiras e embaralhamento das categorias que separam os homens, os animais e os deuses".

Nessa experiência da alteridade, do confronto com o outro, visto tanto em termos da oposição entre civilizado e selvagem ou da natureza e cultura qual seria o papel delimitador exercido pela agorá, a assembléia? Em que medida poder-se-ia considerá-la como eixo de referência norteador desse jogo de oposições? A ligação entre selvageria e ausência de agorá, como se apresenta na crítica a respeito do episódio dos Ciclopes, faria parte do conceito de selvagem (ágrios) contido na épica?

Tomando-se como referência a pergunta formular, com a qual Odisseu manifesta suas preocupações para com os tipos de gente que poderia encontrar nas terras desconhecidas as quais chega - serão desmedidos, selvagens (ágrios) e injustos, ou hospitaleiros tementes aos deuses? - seria adequado, considerar que haveria uma clara vinculação entre a idéia de selvagem contida nessa fórmula e a ausência de assembléias?

Na fórmula, o comportamento selvagem é contraposto à hospitalidade e a piedade. Como se viu anteriormente, a utilização formular do vocábulo ágrios, quando associado ao comportamento humano, remete, em um primeiro plano pelo menos, a idéia de ferocidade incontida, sentido que se casa bem com os versos acima: as gentes que habitam essas terras seriam ferozes ou cordiais?

A Cordialidade para com os estrangeiros e suplicantes é vista como preceito divino e sua não observância implica cair na impiedade. Serão selvagens ou tementes aos deuses, esse é o par da oposição a qual a indagação de Odisseu se refere. 
Porém, no início deste capítulo, vimos que a crítica histórica contrapõe a ausência de assembléias entre os Ciclopes e não a impiedade como campo delimitador do civilizado e do selvagem. Agora se em um primeiro plano a idéia de selvagem esteja vinculada a impiedade, em um segundo plano, poderíamos associar a impiedade a ausência de agorá, de tal modo que todos os que apresentam comportamento impiedoso não constituíssem laços associativos que unisse a comunidade em torno de uma assembléia? Somente em caso de uma resposta afirmativa para essa pergunta é que poderíamos concluir pela validade da associação do conceito de selvagem com o de ausência de agorá na épica.

De maneira geral a narrativa não apresenta uma associação rígida entre forma social e comportamento impiedoso. No espaço das "errâncias" dois povos são explicitamente citados como possuidores de agorá: os Feácios e os Lestrigões. Os primeiros honraram e acolheram Odisseu, os segundos eram canibais que mataram e comeram a maior parte de seus homens. Eólo vive com sua família, isolado, rodeado pelos seus filhos que se casam entre si. Próximo aos deuses, ele é o intendente dos ventos. Odisseu é bem acolhido por ele. Vivendo solitáriias temos Circe e Calipso que se alimentam de néctar e ambrosia, como também Polifemo, que como carne humana. Não há na narrativa sobre as gentes fantásticas que Odisseu encontra em sua viagem a vinculação direta entre forma social e comportamento piedoso. Como também em toda a épica não há exemplo de algum povo situado fora desse espaço que não possuísse assembléias, não havendo nada que se poderia assemelhar com o registro de Heródoto a respeito de Ciro, contrapondo a experiência organizativa de povos que possuem assembléias, os gregos, e os que não possuem, os persas. Athêmistos (sem lei/regras) são tanto os pretendentes que vivem em Ítaca, os Lestri- 
gões, os Ciclopes e Polifemo, com cada um deles vivendo experiências sociais distintas. O conceito de selvagem e iniqüidade em Homero não parece se associar à formas organizativas específicas. Forma de pensar cara à constituição do pensamento ocidental, que teve seu auge no século XIX, mas ainda presente nos estudos clássicos, e na política imperialista da(s) grande(s) potência(s). 
4- As REUNIÕES NA ÁGORA DE ÍTACA 


\section{1- A Assembléia de Telêmaco}

A assembléia Od.2.1-259 é convocada por Telêmaco, a conselho de Atena, que, disfarçada na figura de Mentes, o incita a tomar atitudes que pudessem levá-lo a expulsar os pretendentes de sua casa. Para convocá-la, acorda cedo, com o sur-

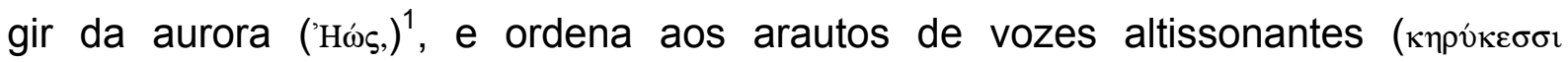

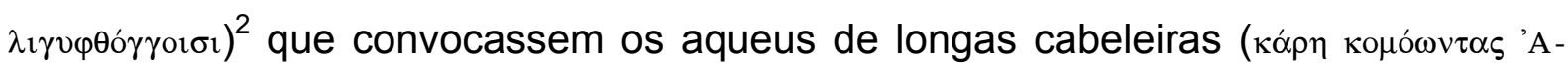

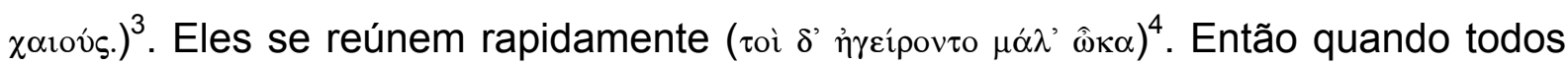

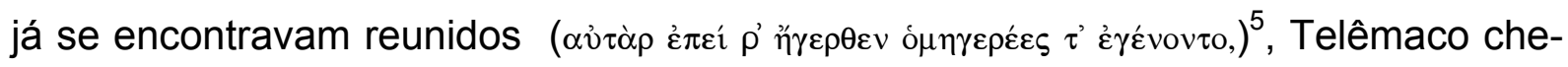
ga e os homens $(\pi \alpha \dot{v} v \varepsilon \varepsilon \varsigma \lambda \alpha o i)^{6}$ contemplam-no

Assim que, nascida pela manhã, surgiu a Aurora de róseos dedos, o filho de Ulisses levantou-se do leito e enrolou as suas roupas; depois passou por sobre o ombro a sua espada aguçada, atou sob os pés brilhantes as suas belas sandálias e saiu do quarto, belo como um deus. Imediatamente deu ordens aos arautos de voz clara para convocarem à assembléia os Aqueus de longos cabelos. Os arautos lançavam o apelo e os Aqueus juntavam-se com presteza. Quando, então, eles se acharam reunidos em grande número, Telêmaco avançou para a assembléia, apertando na palma da mão um dardo de bronze; não estava sozinho: dois cães correndo seguiam-no. Era maravilhosa a graça que Atenas derramara sobre a sua pessoa; por isso a sua entrada atraía todos os olhares (todos os laói contemplaramno).(grifo nosso $)^{7}$

\footnotetext{
1 Odisséia 2.1.

${ }^{2}$ Odisséia 2.6.

${ }^{3}$ Odisséia 2.7.

${ }^{4}$ Odisséia 2.8.

${ }^{5}$ Odisséia 2.9.

${ }^{6}$ Odisséia 2.13.

${ }^{7}$ Odisséia 2.1-13.
} 
A cena segue os padrões de composição empregado para narrar a convocação de outras assembléias descrita na épica. $\mathrm{Na}$ a assembléia realizada após Agamêmnon ter recebido o "sonho enganador", a cena de convocação é descrita de forma similar

\begin{abstract}
A deusa Aurora ('Hìs) aproximava-se do vasto Olimpo, a fim de anunciar a luz a Zeus e aos outros imortais. Então o rei ordenou aos

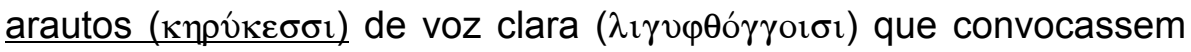
os cabeludos Aqueus para a praça. Os arautos convocaram e eles se reuniram rápidamente ${ }^{8}$.
\end{abstract}

Também encontramos os mesmos elementos narrativos, apresentados com algumas variações, na convocação da assembléia feita por Alcínoo na Feácia. Para convocá-la, ele se levanta bem cedo e, junto com Odisseu, dirige-se para a praça.

Logo que, nascida pela manhã, raiou a Aurora de róseos dedos, o forte e valoroso Alcínoo saltou da cama, e de igual modo se levantou o descendente de Zeus, Ulisses saqueador de cidades. E o valoroso Alcínoo guiou-o a caminho da ágora dos Feáces, edificada perto de suas naus. Chegados lá, sentaram-se um ao lado do outro sobre as pedras polidas. Entretanto ia através da cidade Palas Atena, sob os traços de um arauto do prudente Alcínoo [convocar para a assem${\text { bléia }]^{9}}^{9}$

Um cenário semelhante é descrito por Nestor, na llíada. Ele nos conta que em uma expedição punitiva contra os Eleios, devido a um caso de roubo de bois, obteve grandes despojos, posteriormente divididos entre os que foram roubados pelos Epeus. Para realizar a partilha, Neleu convocou uma reunião: 
Os arautos convocaram claramente, ao surgir a Aurora, os que eram credores de uma dívida na divina Élide; e reunidos, os condutores dos Pílios fizeram a partilha ${ }^{10}$.

Mark Eduard (1988, p.71) observa que os leitores de Homero notam não somente adjetivos formulares recorrentes, mas também cenas repetidas como as de sacrifícios, preparação de carne, combates singulares, visitas de divindades. Cenas de vários tipos que constituem uma vasta gama de atividades pertencentes ao dia a dia, aos cenários de batalhas ou dos momentos de celebração. As type-scenes, como são chamadas, teriam sua contrapartida na forma padronizada com que certas práticas sociais seriam mantidas, constituindo-se em ferramentas para a composição oral dos poemas ou sua memorização, pois a familiaridade com a seqüência uniforme dos elementos de uma cena reduziria o perigo de omitir aspectos importantes de sua estrutura, como também permitiria a elaboração reduzindo a cena a elementos mínimos ou enriquecendo-a com detalhes. No caso da assembléia de Telêmaco,

${ }^{10}$ llíada 11.685-88.

$\mathrm{Na}$ assembléia, Neleu reservou uma manada de bois e um grande rebanho de carneiros para si, pois era credor da maior dívida, dando o resto para o dêmos, sendo a partilha feita pelos chefes dos

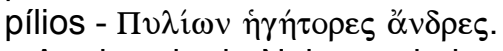

A primazia de Neleu poderia ser motivada por três elementos: ele era o rei e gozava dessa prerrogativa; sendo um botim realizado pela sua casa na figura de seu filho, os despojos the pertenceriam, justificando-se assim sua atitude; como ele teria sido o mais ofendido pelos epeios a ele também caberia a maior parte. Não é possível decidir por nenhuma delas, e nem se é necessário tomá-las separadamente. Seja como for é Neleu quem toma a iniciativa na assembléia, separa a parte do botim que lhe interessa, e dá o resto ao povo.

A partilha foi realizada pelos chefes dos pílios. Quem seriam eles? A cena da convocação contém a menção que os convocados para a reunião eram aqueles que foram ofendidos pelos Epeus. Todos eles seriam chefes dos pílios de tal modo que entre os que foram roubados não haveria quem não fosse chefe?

O contexto não permite tal reflexão, pois não fornece nenhuma informação a respeito. Porém podemos considerar que o relato de Nestor aponta para uma diferenciação, embora não seja possível identificar sob quais bases sociais ela se sustenta. Nela identificamos a figura de Neleu, em uma posição de destaque; os chefes condutores dos pílios; e, por inferência, aqueles que seriam seus seguidores. Quais seriam os conteúdos sociais dessa diferenciação? A narrativa de Nestor não encerra elementos que permitam a responder essa pergunta. 
teríamos uma narrativa expandida, ricamente elaborada, no da "assembléia de Aquiles", um dos exemplos mais econômicos presentes na épica

Durante nove dias caíram sobre o exército as flechas do deus. Ao décimo, Aquiles convocou a tropa (laós) para a ágora. ${ }^{11}$

A cena de convocação da "Assembléia de Telêmaco" constitui-se em uma typescene bem definida, possuindo elementos formulares que indicam a presença de um esquema formal de composição claramente delimitado ${ }^{12}$. Ao amanhecer ordena-se aos arautos de vozes sonoras a convocar para a agorá os aqueus de longos cabelos, que se reúnem rapidamente ${ }^{13}$.

A fórmula "aqueus de longos cabelos" é empregada de maneira genérica para designar o conjunto do agrupamento formado pela tropa de Agamêmnom em Tróia. No contexto troiano, ela é utilizada tanto para a convocação dos homens para a assembléia ${ }^{14}$, como para a batalha ${ }^{15}$. Os aqueus de longos cabelos formam o laós de Agamêmon, como os homens convocados por Telêmaco formam o laós de Ítaca ${ }^{16}$.

\footnotetext{
${ }^{11}$ llíada.1.52-3.

${ }^{12}$ Lord (1960) define a épica oral como poesia narrativa composta em várias gerações por cantores de histórias que não sabiam ler, consistindo-se de estruturas de versos métricos construídos por meio de fórmulas, expressões formulares e da construção por temas. Fórmula é definida por um grupo de palavras regularmente empregadas sob as mesmas condições métricas para expressar uma dada idéia essencial. Expressão formular é o verso ou o meio verso construído sob o modelo de fórmulas. Os temas são os incidentes e as passagens repetidas, descritas em uma canção.

Segundo Lord, um dos temas mais facilmente isolável é o da assembléia, por ter início e final obvio. O tema está presente em vários momentos da épica, marcando a condução da trama, servindo como um dos principais espaços de interação social.

${ }^{13}$ Ilíada 2.51-52 = Odisséia 2.6-8 são formulares.

${ }^{14}$ Ilíada 2.11, 28, 51, 65.

15 llíada 2.443.

${ }^{16}$ Odisséia 2.41.
} 
É o laós de Ítaca que está presente na assembléia para ouvir as queixas de Telêmaco contra os pretendentes: o conjunto formando pelos que estão em condição de lutar, o bando guerreiro constituído pelos homens da comunidade. O povo (laós) estando reunido, começam os trabalhos. Egípcio, descrito como o mais velho, e pai de um dos pretendentes, é o primeiro a falar, perguntando se quem os havia convocado tinha notícias do exército ( $\sigma \tau \rho \alpha \tau o \widehat{)})$ ou algum outro negócio público ( $\delta \eta_{\mu 1}$ tratar

Escutai, Itacenses o que eu tenho para vos dizer. Nunca mais a nossa assembléia se reuniu e nós deliberamos desde que o nobre Ulisses partiu nas suas côncavas naus. Então quem nos convoca hoje? Quem sentiu essa premente necessidade? É um jovem ou um velho? Acaso ouviu falar do regresso do exército e quer dar a conhecer o que soube antes de nós? Ou terá algum outro assunto de interesse público a comunicar e a expor a nossa deliberação? ${ }^{17}$

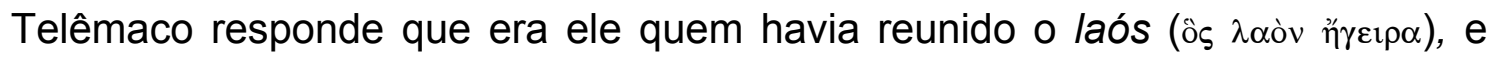

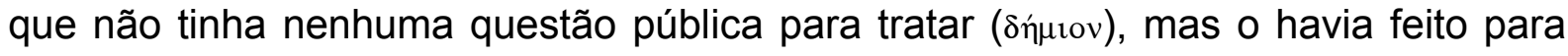
tratar de um negócio de sua própria casa (ơ̌k $)^{18}$

Ancião, não está longe o homem que convocou o povo (laós), e tu vais conhecê-lo sem demora; fui eu próprio, eu a quem a dor atinge mais do que qualquer outro. Não vou falar do regresso do exército; não tenho a intenção de vos dar a conhecer uma notícia de que ti-

\footnotetext{
${ }^{17}$ Odisséia 2.25-32.

${ }^{18}$ Para contrapor o argumento de Finley que o pano de fundo histórico da épica homérica situar-se-ia nos séculos $\mathrm{X}$ e IX, pois não encontraríamos nela a instituição da pólis, Morris afirma que a distinção entre público e privado já estaria bem estabelecida e que o poder da assembléia homérica era considerável. Para ele, a afirmação de Finley de que o mundo de Ulisses seria basicamente fundado no oikos seria equivocada, pois a comunidade, por meio das reuniões da ágora decidem as questões que ameaçam seu equilíbrio. Um dos exemplos que fornece para justificar sua opinião são os versos Odisséia 2.45-6. Finley (p.76) comentando essa passagem, observa que a ágora e a distinção entre questões públicas e privadas eram noções bem estabelecidas na épica, sendo o resultado do lento reaparecimento da comunidade, após a derrocada micênica, porém a Ítaca de Ulisses ainda seria muita ligada à organização familiar e de parentesco.
} 
vesse sabido antes de vós; e não pretendo comunicar e expor à vossa deliberação qualquer assunto de interesse público; sou apenas eu que necessito da vossa ajuda, porque a desgraça caiu sobre minha casa... ${ }^{19}$

Para contrapor o argumento de Finley de que o pano de fundo histórico da épica homérica situar-se-ia nos séculos $\mathrm{X}$ e IX, pois não encontraríamos nela a instituição da pólis, Morris (1986, p.101) afirma que a distinção entre público e privado já estaria bem estabelecida e que o poder da assembléia homérica seria considerável. Para ele, a afirmação de Finley de que o mundo de Ulisses seria basicamente fundado no oikos seria equivocada, pois a comunidade, por meio das reuniões da ágora decidiriam as questões que ameaçassem seu equilíbrio. Um dos exemplos que fornece para justificar sua opinião são os versos Od.2.45-6, nos quais Telêmaco faz menção à natureza da questão que trazia à agorá, dizendo que o assunto que trazia era particular, referente à sua casa. Porém, Finley (lbid., p.76) ao comentar essa mesma passagem, também observa que nela se opera uma distinção entre público e privado, o que seria uma evidência de que essas noções seriam bem estabelecidas na épica, distinção que seria resultado do lento reaparecimento da comunidade, após a derrocada micênica, porém afirma: a Ítaca de Ulisses ainda seria muita ligada à organização familiar e de parentesco. Os dois não negam a importância dos versos como evidência da presença da noção de "público", que teria na assembléia um de seus espaços de manifestação, mas fazem julgamentos diferentes quanto à sua importância na organização da sociedade homérica.

${ }^{19}$ Odisséia 2.32, 45-6. 
Qual seria a importância de cada uma dessas esferas de organização? Em um comentário geral em que fornece um exemplo da llíada, Vidal-Naquet (2002, p.71) observa que é difícil determinar o que constituiria a estrutura dominante do mundo de Homero: a pólis propriamente dita, com seus órgãos de deliberação e decisão, ou o oîkos, o domínio territorial sobre o qual se apoiava o poder dos chefes de guerra. Porém ao se referir explicitamente à Ítaca, comenta que, do início ao fim, o que vemos funcionar não são as instituições da pólis, mas sim o oîkos de Odisseu, que é pilhado pelos pretendentes e sobre o qual se apóia para vencê-los. Nesse sentido, Finley (Ibid. p.88) argumenta que, nessa assembléia, não se dirige uma vez só ao povo, falando somente aos pretendentes. Somente ao seu final é que Mentor se volta para o dêmos censurando-o por não intervir na questão, o que evidenciaria o fracasso de seu projeto de mobilizar a opinião pública contra os pretendentes, transformando assim uma questão privada em uma questão pública.

Essas considerações de Finley possuem lacunas que julgamos interessantes como fontes de questionamentos. Sua observação de que ele fala somente aos pretendentes não seria contraditória com sua conclusão de que Telêmaco havia falhado em seu obejtivo de transforma uma questão particular sua em uma questão pública. Se a sua intenção é a de mobilizar o povo a seu favor por que não se dirigir diretamente a ele? E se, como nos diz Finley, Telêmaco fala somente aos pretendentes, quais argumentos ele teria apresentado para tentar transformar o seu problema particular em um problema público? Aquém Telêmaco se dirige na assembléia? A questão é importante para podermos delinear os contornos dos limites do que seria público ou privado nessa assembléia, e assim identificar o papel a assembléia como espaço deliberativo para solução de conflitos que ameacem o equilíbrio social. 
Na seqüência de sua fala, Telêmaco diz que, contra a vontade dela, sua mãe estava sendo assediada pelos pretendentes. Na corte que faziam a ela, estavam consumindo suas riquezas sem que pudesse fazer alguma coisa, pois não tinha forças suficientes para contê-los. Segundo ele, os pretendentes temiam ir à casa de Icário, pai de Penélope, onde ele próprio contrataria o casamento da filha, com quem Ihe aprouvesse. Ao invés disso, freqüentavam sua casa consumindo seus bens

\begin{abstract}
Certos pretendentes assediam minha mãe contra a vontade dela: são os filhos dos homens que são príncipes (áristoi) de Ítaca; eles não se atrevem a ir a casa de seu pai, Icário, que fixaria os presentes habituais, dando-a depois a um deles, escolhido e preferido por si. Acostumados a passar todo o dia em nossa casa, a sacrificar os nossos bois, as nossas ovelhas, as nossas gordas cabras, eles festejam, bebem o nosso vinho de reflexos de fogo, sem conta; grande é o estrago; pois não há um homem aqui que se possa assemelhar a Ulisses, para afastar a ruína da casa. Eu não estou ainda em condições de o fazer, já que não tenho forças para repelir o mal. Ah! como gostaria de o fazer, se tal poder tivesse $\mathrm{e}^{20}$.
\end{abstract}

Por que os pretendentes não se atrevem a ir à casa de Icário para resolver a questão? Qual seria o motivo projetado pela trama para que isso seja dessa maneira? A possibilidade de resposta para essa pergunta transcende os limites desses versos, exigindo uma análise de contexto mais ampla, porém, por ora, podemos evidenciar um ponto importante para essa discussão: na casa de Icário, os pretendentes iriam oferecer presentes a Icário ou receber dele um dote referente à sua filha? Heubeck (1990, p.133) observa que a resposta dessa pergunta se encontraria no

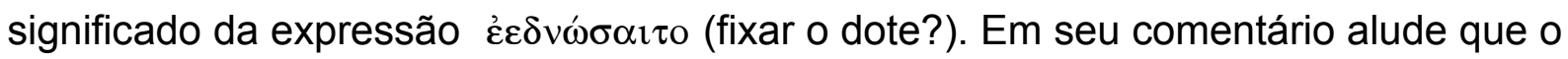
verbo ocorre somente nessa passagem em Homero. Sua interpretação apoiar-se-ia

${ }^{20}$ Odisséia 2.50-62. 
sobre o significado de ع้ $\varepsilon \delta v \alpha$, que na épica serviria para designar tanto os presentes oferecidos pelo noivo, como o dote oferecido pelo pai da noiva. Como ele considera

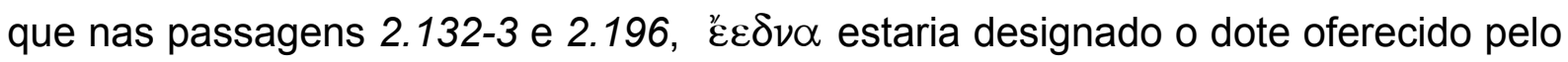
pai da noiva, julga que aqui seria mais natural tomar o significado da expressão

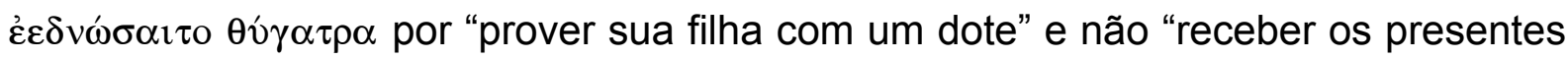
dos pretendentes de sua filha". Snodgrass e Finley, por sua vez, consideram que nesse caso o que estaria em jogo seria os presentes que os pretendentes ofereceriam a Icário e não o dote que receberia dele. Segundo Finley haveria mesmo uma virtual unanimidade entre os comentadores e tradutores que essa passagem estaria se referindo a presentes passando do noivo para os pais da noiva (Morris, 109).

A questão do dote na sociedade homérica é controversa. Snodgrass, argumentando que a épica não retrataria uma sociedade histórica, observa que nela coexistiram práticas de concessão de dotes que seriam incompatíveis de existirem em um único modelo social. Uma delas seria o procedimento do pretendente oferecer presentes para o pai da noiva (ver 8.318; 11.280; 15.16; 15.367; 16.391; 19.529; 21.161). A outra seria o procedimento contrário, o de o pai da noiva oferecer o dote que acompanharia sua filha $(1.277 ; 2.132,196 ; 4.736 ; 7.311 ; 20.341 ; 23.227)$. Por sua vez, onde Snodgrass enxerga a contradição de modelos contrastantes, que indicariam a não historicidade da sociedade retratada na épica, Finley observa um modelo funcional. Segundo ele, os bens oferecidos pelo noivo pela noiva seria um presente do noivo para o pai da noiva que, em compensação, propiciaria um contra dom, que teria como beneficiário o noivo e sua noiva.

Morris comenta que interpretar essa passagem como um exemplo de "dote" na sociedade homérica seria um erro. Para ele tanto Snodgrass como Finley teriam 
exagerado ao contrastar duas formas distintas de contratação de casamento em Homero. Para ele, seguindo Lacey (1966), a maior parte dos exemplos cotados como um caso de dote seriam equivocados, pois se tratariam de presentes ( $\delta \hat{\omega} p \alpha)$ trocados em ambas as direções para estabelecer boas relações entre os parentes da noiva e seus pretendentes potenciais. Segundo Lacey (Morris 106) o modelo padrão de prática de casamento em Homero iniciar-se-ia com essa prática, posteriormente os pretendentes ofereceriam seus presentes( $(\varepsilon \delta \delta \alpha \alpha)$ pela noiva. Assim para Morris, Telêmaco estaria aludindo que os pretendentes não queriam ir à casa de Icário para oferecer presentes a ele, porém discordando de Finley, considera que, eles ofereceriam presentes que não poderiam ser interpretados como um caso de dote (p.109).

Após ter feito o pedido para que os pretendentes fossem à casa de Ícario, Telêmaco observa que a situação em que se encontrava não era mais tolerável, então muda a tônica de seu discurso. Ele começara afirmando que trataria de uma questão de sua própria casa, observando que os pretendentes estavam se comportando de maneira errada, consumindo os seus bens, mas ao clamar para que saíssem de sua casa, não se dirige diretamente a eles, mas ao resto da assembléia: "Indignai-vos também vós outros; envergonhai-vos diante dos outros homens em nossa volta, os que habitam as vizinhanças; temai a cólera dos deuses!"

O comportamento dessa gente deixou de ser tolerável; a ruína da minha casa é uma infâmia. Indignai-vos, pois, vós também; temei o juízo de nossos vizinhos, dos povos que nos rodeiam; receai a cólera 
dos deuses; tende cuidado para que a ira deles não faça recair a pena de tais atentados sobre vós mesmos. ${ }^{21}$

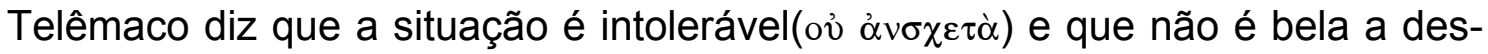

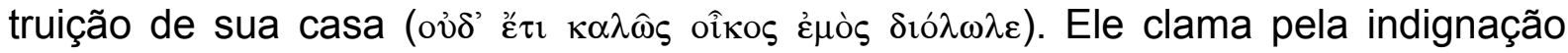
(nemesis) de todos contra os atos vis praticados pelos pretendentes, dizendo que eles têm que se envergonhar e temer a cólera dos deuses. O conjunto da comunidade é envolvido na questão. As más obra dos pretendentes deve motivar a indignação, levando-os a contê-los. Caso isso não ocorresse, todos deveriam temer a vergonha perante os homens e a cólera divina.

Então, após apelar para o sentimento de indignação contra os pretendentes, Telêmaco, de forma surpreendente, dirigindo-se para o conjunto da assembléia, pede para que os presentes se contivessem, a menos que seu pai, no passado, tivesse agido mal para com eles e, agora, instigando os pretendentes contra ele, estivessem se vingando na sua pessoa

Suplico-vos, por Zeus Olímpio, e por Têmis, que as assembléias dos homens dispersa e congrega, refreai-vos, amigos, e deixai-em só, consumido pelo amargo luto - salvo se , por acaso, meu nobre pai, Odisseu, agastado, tenha causado males aos aqueus de boas cmênides e vós, agastados estejai em desforra, instigando essa gente, afim de causardes minha ruina e dispersa (trad. Jaime Bruna) ${ }^{22}$. 
A opção por utilizar a versão de Jaime Bruna deve-se à tradução que Cascais

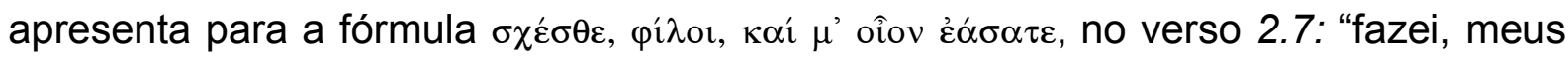
amigos, que esses abusos cessem, afim de que eu possa entregar-me ao luto que me aflige na solidão de minha casa". $Z \chi \varepsilon \dot{\varepsilon} \sigma \theta \varepsilon$ é a segunda pessoal do plural do aoristo imperativo médio de $\varepsilon$ k $\chi \omega$ (portar, reter, ter nas mãos, conter, ect) ${ }^{23}$. A opção pelo "fazei" de Cascais por si só não seria inconveniente, pois o problema se encontra no complemento que destina a ele: "que esses abusos cessem". Essa tradução pode induzir o leitor de que a suplica de Telêmaco dirige-se no sentido de pedir ajuda dos demais presentes na assembléia contra os pretendentes, já que os abusos estariam sendo praticados por eles. Mas esse não é o caso aqui, o que pode ser claramente percebido pela opção de Cascais ao traduzir essa mesma fórmula em uma passagem da llíada. Trata-se do verso 22.416 .

Aquiles, após ter matado Heitor, ultraja o seu cadáver diante dos muros de Tróia. Fura-lhe os tendões dos dois pés. Passa-lhes uma corda pelos furos e o amarra em seu carro, com a cabeça arrastando pelo chão. Desesperado diante dessa cena, seu pai, Príamo, busca transpor os muros da cidade para ir a direção ao seu filho. O povo tinha dificuldade para reter o ancião, que se zangava, impaciente por transpor as portas da cidade. Ele suplicava a todos, revolvendo-se na imundície, nomeando cada homem pelo seu nome:

Cessai, amigos, e deixai-me sozinho, apesar das vossas inquietudes, sair da cidade e ir aos navios para ir aos navios aqueus. Quero suplicar àquele homem louco de orgulho, àquele violento, para ver se respeita a minha idade e tem piedade da minha velhice.

${ }^{23}$ VECCHI, P. e SACCHI, F. Verbi Greci. 
Na fórmula em questão, $Z \chi \varepsilon \varepsilon \sigma \theta \varepsilon$ não tem complemento, é intransitivo. Príamo não está pedindo para que o povo "faça cessar" alguma coisa que fosse exterior a ele, mas pede para que ele pare de impedí-lo de sair. Para que cesse com o próprio comportamento e não com os dos outros. O inconveniente da tradução apresentada por Cascais, na Odisséia, é que ao verter a fórmula por "fazei, meus amigos, que esses abusos cessem", pode-se induzir o leitor a pensar que Telêmaco, nesse momento, pede ajuda dos demais contra os pretendentes. Porém o que ele faz aqui não é isso, mas sim pedir para que todos se contivessem e se refreassem. Assim a opção de Jaime Bruna nos parece mais adequada: "refreai-vos, amigos, e deixai-me só". Como bem observa Heubeck, ao invés de apelar por ajuda contra os pretendentes, Telêmaco pede para que os Itacenses se contenham e parem de incentivar os pretendentes contra ele (135). O caso é particular, mas Telêmaco envolve toda comunidade. Segundo ele, os malfeitos dos pretendentes exigiam respostas de todos, a menos que todos os demais estivessem agindo em vingança contra ele, mas, nesse caso, ele diz: pilhai-me logo de uma vez! Como bem observa Heubeck, Ao invés de acusar diretamente os pretendentes, Telêmaco alude à possibilidade do conjunto da comunidade estar instigando os pretendentes contra ele.

Os elementos de sua fala se articulam de tal maneira, que nos alerta para a necessidade de cautela. As relações entre o que é uma questão pública ou particular não parecem ser bem definidas. Pela fala de Telêmaco, ela é particular, pois afeta a ruína de sua própria casa. Porém, segundo ele, as conseqüências dos atos dos pretendentes seriam de alcance coletivo, já que a vergonha e a cólera dos deuses recairiam sobre todos. 
Diante de uma injustiça que se praticava contra ele, Telêmaco acusa o povo (laós) presente na assembléia responsabilizando-o por apatia ou cumplicidade. Para Heubeck, sem explicar o por quê, tal comportamento deve ser visto como uma distorção emocional motivada pela juventude e inexperiência de Telêmaco. Não temos como inferir os motivos de seu julgamento, mas podemos analisar as suas implicações para nossa análise. Com o seu juízo, Heubeck mantém a questão como um assunto de ordem particular. A referência de Telêmaco, acusando o povo de responsabilidade por cumplicidade, refletiria um estado emocional típico de pessoas imaturas, que enxergam seus problemas sempre como culpa dos outros. Com esse comentário, a dimensão pública dos argumentos de Telêmaco é esvaziada, sendo interpretada somente como um desvio psicológico próprio da imaturidade. Porém consideramos que melhor seria observar essa manobra como uma estratégia discursiva, que demonstra a dimensão pública da questão. Ele não segue a risca o plano de Atena de convocar uma assembléia e lá, publicamente, exortar os pretendentes a abandonar sua casa. Aqui ele busca o apoio da assembléia contra eles. Para obtê-lo clama de tal forma que não the deixa a possibilidade da neutralidade: se a assembléia não agir, seus membros são responsáveis por apatia ou cumplicidade. Muito mais do que manifestação de sua inexperiência, consideramos o discurso de Telêmaco manifestação de uma tática discursiva altamente elaborada, estreitamente relacionada ao plano geral da narrativa.

Os elementos apresentados em sua fala encontram eco nos discursos que se seguem. O primeiro que se levanta em resposta é Antínoo, buscando negar um dos pontos basilares do argumento de Telêmaco: o de que sua mãe era assediada contra a vontade dela, e que os pretendentes se negavam ir à casa de Icário. Segundo ele, a própria Penélope era a culpada pela situação, pois a todos entretinha com es- 
peranças. Então aconselha Telêmaco a dispensar a mãe para a casa de seu pai e lá tomar as núpcias a quem aprouver a Icário

Telêmaco de alto falar, de imoderada audácia, que dissestes para nos cobrir de vergonha? Quererias sem dúvida amarrar uma ignomínia às nossas pessoas. Mas de quem é a culpa? Não dos pretendentes aqueus, mas da tua própria mãe; porque não há mulher alguma que seja mais entendida nas manhas. Há já três anos, em breve quatro, que ela ludibria o coração dos aqueus em seus peitos. A todos ela faz acalentar esperanças; a cada um de nós ela promete, envia mensagens; mas tem outros projetos na cabeça. Eis o último subterfúgio que o seu espírito imaginou: ela colocou no seu quarto um grande tear para nele tecer um véu fino e longo: no mesmo instante veio dizer-nos: "jovens, meus pretendentes, instais pelo meu casamento; o ilustre Odisseu morreu; esperai então até eu ter acabado este véu; evitai que todos esses fios sejam em pura perda; será a mortalha do senhor Laertes, no dia em que ele tiver sucumbido ao golpe funesto da Morte cruel. Não façais de modo algum a que alguma das mulheres de Acaia vá falar ao povo contra mim, indignada por ver sem sudário um homem que ganhou tantos bens!" Eis o que ela dizia, e nós rendemo-nos, mau grado o orgulho de nosso coração. Então, de dia ela tecia o grande véu, e, à noite, desmanchava a sua obra, à luz das tochas. Assim, durante três anos, ela soube esconder o seu ardil e enganar os Aqueus. Mas quando, com o retorno das estações, chegou o quarto ano, uma das suas mulheres, que sabia tudo, revelou-nos o seu artifício, e nós surpreendemo-la desfazendo o brilhante tecido. Foi desta maneira que ela teve de acabar a obra, de má vontade e constrangida. Eis o que te respondem os pretendentes, para que no teu coração saibas a verdade, e que todos os Aqueus a conheçam. Manda embora a tua mãe, insiste para que ela case com aquele que seu pai designar e souber agradar-lhe ela própria. Mas se, graças a tantas demoras, ela continuar a vexar os filhos dos Aqueus, vaidosa em seu íntimo por Atena a ter contemplado com os seus dons mais do que a qualquer outra, ciência dos esplêndidos lavores, agudeza de espírito, ardis tais que os não tiveram noutros tempos aquéias famosas, mulheres de belos caracóis, Tiro e Alcmena e Micena de brilhante diadema - nenhuma possuía tanta astúcia como Penélope -, desta vez o seu cálculo sai falso. Pois os pretendentes comerão os teus víveres e os teus bens durante tanto tempo quanto ela se obstinar no desígnio que os deuses lhe incutem no peito. Ela ganha para si uma grande glória, mas para ti o pesar por tantos víveres! Nos não iremos para as nossas terras nem para sítio algum antes de ela ter desposado o aqueu que souber agradar-lhe ${ }^{24}$. (grifo nosso)

${ }^{24}$ Odisséia 2.85-128. 
Antínoo articula a questão "da causa" no sentido contrário ao de Telêmaco, dizendo que sua mãe era a culpada pela desgraça que se abatia sobre sua casa. De forma também surpreendente, ele afirma que Telêmaco deveria mandar sua mãe de volta para a casa de seu pai, para que lá eles pudessem pedí-la em casamento, dizendo claramente que não eram eles que se recusavam ir a casa de Icário, mas que seria isso exatamente que fariam, caso Penélope fosse mandada para lá.

"Telêmaco, nós vamos a casa de Icário, conquanto que você envie sua mãe para lá" é a resposta que Antínoo lhe dá. A estratégia discursiva de Antínoo obriga Telêmaco a mudar, pois seus argumentos iniciais foram derrubados. Telêmaco se recusa dispensar sua mãe contra a vontade dela. Mandar sua mãe de volta desse modo seria um malfeito e como tal acarretar-lhe-ia sanções. Procedendo assim, teria de pagar alta compensação a Icário, sofreria a indignação dos homens e a perseguição das Erínias.

Sua resposta articula três esferas distintas que se incumbiriam de vingar o ultraje cometido à sua mãe. (1) Ele sofreria retaliação do outro oîkos envolvido, tendo de restituir o dote de sua mãe. (2) Estaria sujeito a indignação do conjunto da sociedade, que reprovaria sua conduta. E, finalmente, a terceira, seria perseguido pela cólera divina. Telêmaco diz temer exatamente as três esferas que alude ao clamar para os pretendentes abandonem sua casa: o oîkos, a comunidade e os deuses

Antínoo, seja como for, não posso expulsar de casa contra a sua vontade aquela que me deu à luz e me criou. Não sei se meu pai está vivo algures ou se faleceu. Seria desgraça para mim pagar tanto a Icário, se porventura me resolver a despedir minha mãe. Além dos males que terei de suportar por parte de seu pai, um demônio enviar- 
me-á outro; pois a minha mãe invocará contra mim as Erínias, por ter partido de casa, e ainda ficarei exposto à indignação dos homens. Por isso não espere que eu pronuncie tal sentença $a^{25}$.

Na resposta que Telêmaco dá a Antínoo é aberta mais uma frente de argumentação. Ao lado dos empecilhos à devolução de sua mãe, ele traz à tona outro ponto: Odisseu estaria vivo ou morto. Para Heubeck (Ibid.), esse verso se encontraria solto em seu contexto, pois o fato de Odisseu estar vivo não seria um obstáculo aparente para a corte que faziam, pois na seqüência os próprios pretendentes aludem que o enfrentariam se ele voltasse. Porém não é isso que nos parece. A observação de Telêmaco está estreitamente relacionada ao jogo de argumentação e contra argumentação presente nessa discussão. Antínoo havia dito que era o comportamento dúbio de Penélope, a dar esperança a todos, que instigava os pretendentes em sua corte, e que eles não se recusam ir à casa de Icário, pois seria exatamente isso que fariam, se Penélope fosse mandada de volta para a casa do pai. Com tal observação, a estratégia inicial de Telêmaco, afirmando que eram os pretendentes que temiam ir à casa de Icário, perde sentido. Agora ele precisa de outro argumento. Diante da dúvida da morte ou não de seu pai, como mandar sua mãe embora?!

Antínoo invertera a situação, o que primeiro fora apresentado como causa do comportamento inadequado dos pretendentes, ele agora apresenta como causados pela própria Penélope e Telêmaco. Para ele, não é o comportamento dos pretendentes que o levará à ruína, mas o de Penélope que, agindo assim, obtém fama e renome, porém deixa-lhe a ruína e uma vida futura desprovida de conforto. "Se livre dela que você se livrará de nós" é o seu conselho. Porém Telêmaco não pode fazer

${ }^{25}$ Odisséia 2.130-7. 
isso, sofreria sanções terríveis se assim procedesse. Ele não nega o comportamento de Penélope, apenas diz que não pode mandá-la de volta, contra a vontade dela. Seria um malfeito que the acarretaria a sanção da casa de Icário, desonra e perseguição divina! Antínoo, de maneira hábil, opõe os interesses de Telêmaco ao de Penélope.

A situação é difícil para Telêmaco, que não tem forças para expulsá-los, nem pode mandar sua mãe embora. É nesse momento que ele alude à possibilidade de seu pai estar vivo, como mais um motivo para justificar sua posição. Então, finalmente, como assim aconselhou Atena, exorta os pretendentes, se quiserem continuar a corte, a providenciar banquetes, consumindo os próprios recursos

\begin{abstract}
Se o vosso coração censura o vosso comportamento, saí do meu palácio, preparai outros festins, comei os bens que vos pertencem, banqueteando-vos uns em casa dos outros alternadamente. Se vos parece mais proveitoso e mais digno consumir sem qualquer reparação a subsistência de um só pois bem, pilhai-o! Por mim, elevarei o meu grito aos deuses eternos, e veremos se Zeus castigará estes excessos. Então, poderíeis perecer no meu palácio sem serdes vingados $!^{26}$
\end{abstract}

Nesse momento, quando a tensão da assembléia começa subir, Zeus envia um sinal, interpretado por Haliterses, que Ihes diz que deveriam refrear os seus comportamentos, pois Odisseu não restaria por muito tempo longe, e muitas calamidades sobreviriam com sua volta

${ }^{26}$ Odisséia 2.138-45. 
Escutai agora, Itacenses, o que eu vou dizer. É sobretudo aos pretendentes que se dirige a minha profecia; pois na direção deles rola um grande desgraça. Ulisses não ficará por muito tempo longe dos seus; já bastante perto, ele prepara para todos aqueles o assassino e a morte; e haverá ainda muitos outros que padecerão entre os que habitamos Ítaca visível ao longe. Procuremos, sem esperar, os meios de fazer cessar os excessos dos pretendentes. Mas seria preferível que eles renunciassem por si mesmos; é do seu interesse tardar o menos possível. ${ }^{27}$ (grifo nosso)

A fala de Haliterses segue em conexão estreita com a discussão que se estabelecera. Telêmaco exortara os pretendentes a realizar a corte consumindo os seus próprios recursos, caso não quisessem sofrer as punições de Zeus. É exatamente após essa afirmação que Zeus envia-lhes essas duas águias. Ao interpretar o vôo delas, Haliterses elucida um importante ponto de dúvida lançado anteriormente por Telêmaco: seu pai estaria vivo ou morto?

Envolvendo o conjunto da comunidade, ele, como Telêmaco, não trata a questão como se fosse exclusivamente privada. Diz falar principalmente aos pretendentes, porém adverte sobres os males que recairiam sobre muitos outros, pedindo então que, se os pretendentes não cessassem tais abusos por conta própria, todos os outros deveriam pensar uma maneira para refreá-los. Em resposta, Eurímaco, um dos pretendentes, ameaça Haliterses. Não aceitando o vaticínio, diz-Ihe que Odisseu está morto. Assim ele não deveria incitar a cólera de Telêmaco, pois que nada poderia fazer diante do maior número que os pretendentes representavam. Então, repete o conselho de Antínoo, dizendo a Telêmaco que enviasse sua mãe para a casa de seu pai, pois lá seriam preparadas as bodas, e expostos copiosos presentes de núp- 
cias, todos quantos devem acompanhar uma filha dileta. Enquanto isso não fosse feito, eles continuariam em seu solar, consumindo os bens de sua casa

\begin{abstract}
Velho, farias melhor se tornasses a casa e guardasses as tuas profecias para os teus filhos, aquém pode vir acontecer uma desgraça. Em adivinhação sou bem melhor profeta do que tu. Há inúmeras aves que andam sempre para cá e para lá sob os raios do sol sem anunciarem sempre os fados. Quanto a Ulisses, pereceu longe daqui, e lamento que tu não tenhas perecido com ele; não emitirias tantas profecias, e não excitarias assim a cólera de Telêmaco, na esperança de que ele te faça um presente útil para tua casa. Vou-te dizer uma coisa, que certamente se realizará: se abusares da tua velha, da tua grande experiência para enganar um jovem, se as tuas palavras o incitarem a teimar, é acima de tudo a ele que isso mais custará; e os que nos escutam impedi-lo-ão sem dúvida de fazer seja o que o que for $^{28}$.
\end{abstract}

O tom de Eurímaco é agressivo. Assume um discurso de força, dizendo que os pretendentes não temiam ninguém. Porém aqui encontramos explicitado um elemento que reforça a análise que fizemos dos discursos de Telêmaco e de Haliterses. Eurímaco diz que Haliterses não deveria incitar a cólera de Telêmaco, porém notamos que não é a Telêmaco que Haliterses se dirige, mas sim ao conjunto dos habitantes de Ítaca. Em sua predição, a vingança de Odisseu recairia sobre todos, e é ao conjunto da comunidade que exorta agir para cessar o comportamento abusado dos pretendentes. Haliterses, como Telêmaco, alçou a questão para o nível comunitário, retirando-a da esfera particular. Eurímaco, por sua vez, diz que o adivinho estaria incitando a cólera de Telêmaco, quando na verdade vimos que incita o povo todo contra eles. Notamos ai a mesma estratégia discursiva apresentada na altercação 
Telêmaco-Antínoo. Um lado se esforça para dar a questão um tom comunitário, o outro para mantê-la na esfera particular.

A radicalização de Eurímaco coloca Telêmaco em uma situação difícil, pois a esse restaria apenas aceitar o conselho de mandar sua mãe embora, coisa que não queria fazer, ou abertamente lutar contra os pretendentes, coisa para qual não possuía forças. Encurralado, Telêmaco muda de assunto, dizendo que não falaria mais a respeito das bodas de sua mãe. Então pede para que lhe fosse fornecido um barco veloz para ir a Pilos e Esparta indagar sobre seu pai. Caso, depois disso, viesse a saber que seu pai estivesse morto, voltaria e daria sua mãe a um marido

\begin{abstract}
Eurímaco e vós todos, nobres pretendentes, não vos solicito mais sobre esse assunto; não volto a falar-vos dele: os deuses e todos os aqueus sabem agora aquilo com que devem contar. Mas dêem-me uma nau veloz e vinte companheiros para a ida e a volta. Irei a Esparta e Pilos das Dunas informar-me do regresso de meu pai há já tanto tempo ausente: talvez algum mortal me fale disto, ou ouça uma voz vinda de Zeus, que é o que a maior parte das vezes traz notícias aos homens. Se me comunicarem que meu pai está vivo e deve voltar, então, não obstante minha ruína, aguardarei ainda um ano; se me disserem que está morto e desaparecido, tornarei ao meu país a fim de lhe erguer um monumento, de lhe prestar todas as honras fúnebres a que tem direito, depois darei a minha mãe um marido ${ }^{29}$.
\end{abstract}

Então diante da passividade da assembléia, que não se manifestava, Mentor, tomando a palavra, profere seu famoso discurso, no qual faz alusão ao "dêmos"

Escutai agora o que vou dizer, itacenses. Para que serve um rei munido de ceptro, seguir o seu pendor para a douçura e a clemência, mostrar sentimentos de eqüidade? Tanto melhor se ele for sempre cruel e se os seus atos forem iníquos, já que ninguém se recorda do

${ }^{29}$ Odisséia 209-23. 
divino Ulisses entre este povo (laói), de que ele era rei e para o qual tinha a douçura de um pai. Que os pretendentes sejam arrogantes, vá; que eles cometam suas violência e se entreguem à sua malignidade, vá. Porquanto eles jogam as suas cabeças, no momento em que, por um abuso de força, devoram a casa de Ulisses, afirmando que ele já não volta. Mas é o povo (dêmos) cuja conduta me indigna: pois como ficais aí sem dar palavra nem dirigir censuras a este punhado de pretendentes, sem por termo a seus excessos; e todavia sois o número! ${ }^{30}$

Aqui a estratégia de alçar a questão para a esfera comunitária se apresenta novamente. Em sua fala, Mentor fixa-se no principal motivo apresentado por Eurímaco para justificar a força que possuíam: eles formavam o maior número, e Telêmaco estava sozinho, por isso deveria aceitar os conselhos dos pretendentes.

Mentor dirige-se aos itacenses em geral e não aos pretendentes, articulando elementos que justificariam o levante do povo contra eles. Para ele, o fato de Odisseu sempre ter sido cordato e reinado com a brandura de um pai é colocado como fundamento básico para a ação em favor de Telêmaco. Ele não ameaça o povo com a punição divina, mas alude à lealdade que deveriam prestar a sua casa. Mentor fecha o círculo. Telêmaco havia começado pedindo para que todos os outros também se indignassem com os abusos cometidos contra sua casa. Agora, Mentor indigna-se com o povo em geral. E se Telêmaco nada podia fazer, pois os pretendentes infringiam danos pela utilização da força, a mesma coisa não justificaria a passividade do povo (laói), já que eles contavam com a maioria e os pretendentes formavam um pequeno número.

Evernor, o último a falar, acusa o golpe, respondendo prontamente. Chamando Mentor de louco, censura-o por tentar levantar os outros contra eles, dizendo que

${ }^{30}$ Odisséia 2.229-41. 
mesmo a gentes mais numerosas seria difícil enfrentá-los. E até mesmo Odisseu, se voltasse, morreria em seu solar

Insolente Mentor, espírito em demência, que palavra te saiu dos lábios! O quê! Excitas o povo contra nós! É penoso ainda que se tenha vantagem do número, correr o risco de uma batalha por um festim. Se o itacense Ulisses, surgindo em pessoa, sentisse no coração a vontade de expulsar os nobres pretendentes surpreendidos a festejar na sua sala grande, o seu regresso não seria uma alegria para a esposa, que tanto o deseja, e ele encontraria logo ali um fim vergonhoso contra adversários superiores em número ${ }^{31}$

Evenor não apenas responde a Mentor, afirmando que eles, os pretendentes, não temiam o resto do povo (dêmos), mesmo esse sendo em número superior, mas também faz alusão às observações de Haliterses que havia afirmado que Odisseu ainda estaria vivo. Sua resposta de que mesmo se Odisseu voltasse não poderia enfrentá-los, demonstra que ele não está vinculando a corte que fazia, consumindo os bens da casa de Telêmaco, ao caso de Odisseu estar vivo ou não, apoiando assim o seu comportamento simplesmente na força que possuíam. Suas palavras aludem que os pretendentes não sairiam da casa de Odisseu mesmo com a sua volta. A mesma situação parece também ocorrer quanto ao casamento de Penélope com algum deles.

A questão que se coloca aqui à interpretação é a de que, havendo o casamento de Penélope, os pretendentes abandonariam o solar de Odisseu, deixando-o para Telêmaco, ou não? Esse mesmo problema também aparece na fala em que Atena aconselhou Telêmaco a convocar a assembléia. Ela Ihe diz que era para ele fazer

${ }^{31}$ Odisséia 2.243-56. 
uma viagem para ir buscar informações sobre o seu pai, observando que, se ele viesse a saber que Odisseu vivia, seria para agüentar mais um ano. Caso se informasse de que ele estivesse morto, seria para dar sua mãe em casamento e arrumar um jeito para matar os pretendentes ${ }^{32}$. Comentando essa passagem, Page (1955, p.56) exemplifica o problema da contradição que ela encerraria com um diálogo imaginário, em que Telêmaco responde a Atenas que entenderia a ordem de matar os pretendentes antes dela se casar com algum deles, mas o que justificaria matá-los após ele ter casado sua mãe, pois ao ser ver, com o casamento, os pretendentes abandonariam sua casa. Assim, a Page, as palavras de Atena surgem como contraditórias.

Em seu comentário sobre essa questão, Thorton observa que os estudos homéricos têm sido abordados pelo viés da Questão Homérica. Nela, os analistas, partindo do que consideram inconsistências, construiriam hipóteses para explicá-las. A principal suposição subjacente, a orientar os seus estudos, seria a questão da múltipla autoria, que teria resultado em um poema composto como se fosse uma colcha de retalhos, cheio de contradições e inconsistências. O outro campo seria formado pelos unitaristas, que entenderiam a obra como um conjunto coeso, sem inconsistências e contradições. Thorton recusa a hipótese de que a fala de Atena seria contraditória, refletindo assim um amalgama de tradições. Segundo ela, uma obra poética deve ser analisada pelo todo e não pelas suas partes. Assim busca elementos no conjunto do poema para explicar a fala da deusa em termos de coerência a um plano geral. Para Thorton, ela guardaria coerência com o quadro geral, pois a real intenção dos pretendentes seria a de destruir a casa de Odisseu e não a de

${ }^{32}$ Odisséia 1.289-96. 
casar com Penélope, como estaria claro principalmente nas palavras de Evenor, em 16.387-92. Desse modo, mesmo após Penélope ter se casado, Telêmaco teria que lutar contra os pretendentes.

Temos, portanto, falas dos pretendentes sinalizando que eles sairiam da casa de Telêmaco, após o casamento de sua mãe, como também temos falas que sinalizam para o sentido contrário, pois o assédio a Penélope se realizava conjuntamente com o assalto à casa de Odisseu, sendo que os pretendentes não estariam dispostos a deixar Telêmaco em paz após o casamento de sua mãe. Seriam as palavras dos pretendentes, afirmando que sairiam da casa de Telêmaco, apenas um jogo retórico criado conscientemente por Homero com a finalidade de contrastar com as suas reais intenções, ou o resultado dos amalgamas produzidos pelo processo de composição do poema?

Outro elemento contraditório também parece ser a apreciação que se faz do povo presente na assembléia. Mentor diz de forma clara que o resto do dêmos, o povo presente na assembléia, deveria coibir os pretendentes, pois se Telêmaco nada podia fazer por ser um só e fraco, eles eram a maioria, portanto os mais fortes. Assim Mentor fica indignado com a falta de ação deles. Qual seria o motivo do silêncio do povo presente na assembléia? A resposta de Evenor parece sugerir que a falta de reação seria motivada por medo, pois, como ele diz, seria difícil mesmo a gentes mais numerosas obrigarem os pretendentes a saírem da casa de Odisseu.

Mas quem seria esse povo que resta mudo na assembléia de Telêmaco? Na primeira altercação, entre Telêmaco e Antínoo, ele aparece como "vós outros". Aqueles a quem Telêmaco, primeiramente, exorta à indignação e, posteriormente, responsabiliza por cumplicidade ou omissão. Na Segunda altercação, entre Haliter- 
ses e Eurímaco, como os "muitos outros" itacenses que deveriam tomar medidas para coibirem os pretendentes, pois os males que sobreviriam, com a vingança de Odisseu, também recairiam sobre as suas cabeças. Nas palavras de Mentor, são os laóis (os homens do bando/bandos) e o resto do dêmos. Na cena de convocação, são os "aqueus de longos cabelos".

Embora, quanto à composição social do agrupamento que se reúne na assembléia o quadro apareça indefinido, a censura de Mentor costuma ser utilizada como um dos principais exemplos de que a sociedade em Ítaca seria bipartida, estando de um lado os "aristoi" (os nobres) e de outro uma camada subalterna, mal definida, identificada pela palavra dêmos. O dêmos restaria mudo, pois fariam parte das camadas inferiores da sociedade. Porém, em que medida, nós poderíamos considerar a grande maioria citada por Mentor como representante de um estrato social inferior? Como "vós outros", "itacenses" e "aqueus cabeludos" não nos dizem muita coisa a respeito das suas condições sociais, uma possível solução para a questão restaria nos significados de dêmos e laós. Mas como resolver o problema da questão da composição social da assembléia pela definição de seus significados, se a respeito deles também não há concordância?

Para nós, o episódio não fornece respostas para essa indagação. A pré-fixação dos significados de dêmos e laós, utilizada como forma de romper a aporia, que essa linha de investigação nos leva, deveria ser considerado mais um problema a ser resolvido do que a solução para o mesmo. Não há concordância a respeito de seus significados, como não há também concordância a respeito de como se estruturaria a sociedade homérica. $\mathrm{O}$ dia em que alguém conseguir, de forma inconteste, definir a estrutura dos grupos que a formariam, de imediato, também se resolveria a questão dos significados dessas duas palavras. Elas aparecem de forma indefinida para 
nós, pois os contextos em que se inserem também são indefinidos. Portanto tentar chegar a uma descrição precisa dos grupos que conformariam a sociedade homérica, por meio de uma operação filológica que busque apreender os verdadeiros significados de dêmos e laós, longe de resolver o problema da aporia, apenas a desloca para outro campo. Se a definição de seus significados passa pela própria compreensão da sociedade homérica, como então utilizar seus significados para desvendá-la? Se o que se busca é identificar os grupos sociais que estariam representados nessa assembléia, não podemos fixar o significado de dêmos, como faz, por exemplo, Finley, pois é evidente que o significado adotado irá determinar a conclusão. A análise empreendida pelo paradigma da "sociedade bipartida" somente se impõe aqui pela fixação dos significados de dêmos e laói, a partir de elementos externos à passagem, vinculando-os a raia-miúda. Temos assim um caso claro de inversão da "regra do contexto", como preconizada por Langlois e Seignobos. Não é a partir do contexto que se acaba fixando o significado do vocábulo, mas sim se utiliza a prédeterminação do significado do vocábulo para se fixar o contexto.

Mas a maneira indiferenciada com as quais as personagens se dirigirem aos presentes na assembléia seria um fator conclusivo para se entender a sociedade homérica também como indiferenciada, sem a presença de grupos sociais distintos? Quem seriam aqueles a quem Mentor recrimina? Teriam o mesmo status social de Telêmaco e os pretendentes, ou fariam parte da raia-miúda? A linguagem empregada pelas personagens, sugerindo a indistinção, referindo-se aos presentes pelos termos genéricos de aqueus ou itacenses, seria a comprovação, como quer Halverson, de que o povo presente nas assembléias homéricas seria composto de um único grupo social? 
Qual seria o melhor encaminhamento. Relacionar os vocábulos dêmos e laós a esses termos genéricos e concluir que também laós e dêmos não expressariam um conteúdo especializado, identificando um grupo social específico, ou seria melhor pré-fixar os seus conteúdos e, a partir deles, interpretar um contexto indefinido quanto a composição social da assembléia? Os dois caminhos têm suas validades, como também apresentam seus problemas. Ambos contribuem a seu modo com o desenvolvimento dos debates e o aprofundamento da questão.

Mas se o povo é chamado à ação, por que ele permanece inerte? Segundo Finley (lbid., p. 88) porque ele restaria neutro e desinteressado, pois tratar-se-ia de uma vingança privada. Trabulsi e Morris que discordam de Finley, quanto ao fato dele considerar que a base da sociedade homérica fundamentar-se-ia basicamente sobre o oîkos, também fornecem a mesma resposta, porém para justificar a importância da assembléia como instância de discussão!

Telêmaco alude a uma questão particular, porém a envolve em um contexto comunitário. A injustiça que se pratica contra a casa de Odisseu pode gerar como resultado a indignação/irritação da comunidade e dos deuses, o que motivaria um movimento de retaliação, punindo os culpados. Mentor apela para a lealdade que povo deveria prestar a Odisseu e, de forma significativa, ao invés de ameaçar-Ihe com a justiça divina, observa que doravante nenhum rei venha ser thano e cordato como ele, pois que isso de nada Ihe havia valido. Há aqui uma clara alusão ao princípio da reciprocidade, que caracteriza o mundo homérico. Odisseu fora bom com o povo e agora esse não the retribuía. Não se indignar, em uma situação dessa, rompendo com um dos princípios básicos da conduta heróica, o da reciprocidade, aca- 
ba por se consistir também em uma falta passível de punição, tanto que Zeus enviaIhes um sinal, advertindo-lhes a respeito da conduta correta. Assim não pensamos que esse episódio caminhe no sentido de evidenciar, mesmo que de forma embrionária, o que é particular e o que é comunitário. Estamos diante de uma situação em que as coisas que se relacionam com a casa real assume conotações e conseqüências comunitárias. Não há aqui um princípio do que é particular se opondo ao que é público, mas sim a interpenetração dos dois. Um esquema de composição que permeia toda a épica. A ofensa de Agamêmnon a Crises e a Aquiles resultou no sofrimento de toda a tropa presente em Tróia. O comportamento de Páris, levando Helena, na destruição de Tróia. De que tipo de reflexão social esse esquema de composição seria reflexo?

Assim nos fica o problema: o povo, denotado nos vocábulos dêmos e laós, seria subalterno aos pretendentes, ou simplesmente não se interessou pela questão? Pergunta que nos remete a outra, já feita anteriormente, quem seria esse povo e quais as suas relações com os pretendentes? E sobre quais bases fundamentar-seia a sociedade itacense e qual seria o papel da assembléia dentro dela? Seria a sociedade homérica relacionada a uma organização tribal, ou refletiriam fortes elementos políades? A resposta pende para um lado ou para outro de acordo com a autonomia que se destina à assembléia como instância de decisão. Essa assembléia, isoladamente, não nos permite responder a essas perguntas. Resta-nos comparála com outros contextos proporcionados pela própria narrativa. 


\section{2 - A Reunião dos Pretendentes}

Se os pretendentes não manifestam preocupação com os demais presentes na "Assembléia de Telêmaco", posteriormente, em outra reunião, se comportam de maneira diferente, temendo a reação do povo (dêmos) contra os atos que vinham praticando. Trata-se de uma reunião restrita. Embora tenha ocorrido na agorá, eles não deixaram ninguém participar dela, nem jovens, nem anciães. Eles se dirigiram para lá após tomarem conhecimento de que Telêmaco, escapando da emboscada que haviam preparado para ele, voltara de sua viagem. Antínoo foi quem começou a falar, dizendo que era necessário que eles pensassem em um meio para matar Telêmaco, pois não cria que eles pudessem realizar seus intentos estando ele vivo

Que contrariedade! Por que seria que os deuses salvaram este homem da morte? Os nossos homens iam postar-se todo o dia nas falésias batidas pelos ventos, revezavam-se sem descanso, e quando o sol se punha nunca passávamos a noite em terra firme, mas vogávamos pelo mar, sobre a nossa nau ligeira, à espera da brilhante Aurora e à espreita de Telêmaco, para o apanharmos e lhe darmos a morte. E durante esse tempo uma divindade conduziu-o a casa. Nós, aqui, preparemos-lhe uma má morte, a esse Telêmaco, e quem dera que ele nos não escapasse; porque, enquanto viver, pelo menos assim o creio os nossos planos não se realizarão. Ele é cauteloso, possui inteligência, decisão, e o povo já não se mostra favorável a nosso respeito! Não deixemos a esse adversário tempo para reunir os Aqueus na ágora; sentirá aversão por nós; de pé, dirá diante de todos que tramávamos traiçoeiramente a sua perda, e que falhamos o nosso golpe. E o povo não nos aprovará, quando the contarem as nossas censuráveis acções. Acautelemo-nos para que não nos inflijam um castigo severo, expulsando-nos de nossa terra, obrigando-nos a procurar refúgio num outro pais. Antecipemo-nos ao nosso inimigo; apoderemo-nos de sua pessoa, longe da cidade, no campo, ou na estrada que conduz até lá; deitemos mão às suas riquezas, a todos os seus bens; partilhemo-nos equitativamente entre nós; e dêmos a sua casa a sua mãe e a quem a desposar. Se esta proposta não vos agrada, se quereis que ele viva e conserve todo seu patrimônio, não 
voltemos a nos reunirmos aqui para the devorar à porfia os seus recursos, caros ao coração do homem, e que cada um, da sua própria casa, prossiga o despique por meio da oferta de presentes. Em seguida, Penélope desposará aquele que Ihe tiver dado mais, e que a sorte lhe destina. ${ }^{33}$

Antínoo agora não demonstra o mesmo desprezo que Evenor manifestou anteriormente pelo povo. Ele teme a sua reação e não quer que Telêmaco convoque uma assembléia para contar-Ihe que sofrera uma tentativa de assassinato, por parte dos pretendentes. O seu temor tem seus motivos, pois seu pai já havia sofrido na própria pele a ira do povo, fato que Penélope Ihe lembra, ao saber da trama contra seu filho

\begin{abstract}
Antínoo, homem insolente e pérfido, dizem em Ítaca levas a palma a todos da sua idade em sabedoria e eloqüência; mas afinal afinal não eras o que se diz! Insensato! Que leva, a ti, a maquinar assassínio e morte contra Telêmaco? Não tens respeito algum pelos suplicantes, cujo queixume é no entanto ouvido por Zeus. Constitui-se um sacrilégio tramar-se a perda dos outros. Que! Não sabes que teu pai chegou aqui fugitivo, por receio do povo, cujo furor era extremo; ele havia se conluiado com os piratas Táfios e molestara os Tesprotos, que eram nossos aliados. Queriam tirar-Ihe a vida, arrancar-Ihe o coração, devorar os seus recursos, cuja quantidade excitava a inveja. Mas Ulisses parou, conteve o povo, não obstante o seu furor. E é agora a casa de Ulisses que tu devoras, sem puxar pelos cordéis à bolsa; requestas a sua mulher, querer matar o seu: e a mim torturasme o coração. Ah! Suplico-te que cesses, e que acalmes os outros. ${ }^{34}$ (grifo nosso)
\end{abstract}

O mesmo povo que os pretendentes diziam não temer agora aparece de maneira ameaçadora. Mudo na reunião de Telêmaco, um dia já quis dar cabo do pai de 
Antínoo, arrancando-Ihe o coração e devorando-lhe os bens. Quem eram eles, que Telêmaco acusa de conivência com os pretendentes, mas que, segundo Antínoo, os perseguiria se soubessem que tentaram matar o filho de Odisseu?

A questão envolvida nessa reunião difere da que foi discutida na assembléia convocada por Telêmaco. Aqui se trata do assassinato de um descendente da casa real. Assunto da mais alta gravidade como bem expressou Anfínomo, respondendo à proposta de Antínoo

Amigos, pela minha parte não consentirei em matar Telêmaco; é terrível fazer perecer o rebento de uma raça real. Procuremos antes de mais conhecer a vontade dos deuses. Se a decisão do grande Zeus nos for favorável, serei o primeiro a querer matá-lo, a incitar todos os outros ao assassínio. Mas se os deuses nos desviarem disso, aconselho-vos a renunciar ${ }^{35}$

Anfínoo é apresentado como um pretendente de coração reto cuja conversa era a que mais agradava a Penélope. A apresentação que lhe é feita antes de suas palavras, confere a ela um grau de adequação, demonstrando que sua opinião era a melhor a ser seguida. A aceitação de sua proposta, com a implícita concordância de todos que, para matar Telêmaco, seria necessário a anuência divina, expressa que aqui os pretendentes seguem um comportamento piedoso, demonstrando temor pelas conseqüências de seus atos. Se juntarmo as palavras de Antínoo, temendo a reação do povo, e a de Anfínoo, temendo a ira divina, notamos que, nessa reunião,

${ }^{35}$ Odisséia $16.400-5$ 
os dois argumentos levantados na "assembléia de Telêmaco", para tentar coibir a ação dos pretendentes também estão presentes. Nela, Telêmaco de forma clara, alegando a péssima conduta dos pretendentes, clama para que os presentes na assembléia, o povo, se voltem contra eles, além de ameaçá-los com a vingança divina, que nesse caso seria irremediavel.

Se as duas possibilidades de sanção, a perserguição do povo e a vingança divina, estão presentes nos discursos, tanto na "Assembléia de Telêmaco", como nesta reunião dos pretendentes, por que na primeira, os pretendentes não se sensibilizaram com elas, e na segunda sim? Na primeira assembléia o assunto em questão era o casamento de Penélope, na segunda, o assassinato de Telêmaco. Seriam dois assuntos de gravidades diferentes, o que justificaria a inanição do povo na primeira, e a crença da sua pronta ação na segunda? Seja como for estamos diante de duas percepções completamente distinta do povo: uma envolvendo fraqueza, omissão e conivência com os pretendentes, outra, força e intolêrancia para com os atos injustos. Como poderíamos resolver essa questão?

Embora deslocando o foco do argumento, das questões de ordem social, para o plano da composição da trama, Thorton com a sua discussão a respeito da contradição ou não da fala de Atena, quando aconselhou Telêmaco a matar os pretendentes após o casamento de sua mãe, nos põe diante de um problema de interpretação, que também nos foi posto pelo debate que apresentamos por meio das opiniões de Finley, Morris e Snodgrass, e que pode ser frutífero para pensarmos essa questão da apreciação do papel do povo na sociedade homérica. Trata-se do problema da coerência ou da incoerência que o texto homérico apresentaria. 
Para Thorton, a Questão Homérica teria sido anulada pelo trabalho de pesquisa de Milman Parry, demonstrando o funcionamento do processo de composição da poesia oral e determinando o papel da tradição como elemento social nesse processo. Porém consideramos que, se o debate a respeito da múltipla autoria foi abalado pela noção de tradição poética oral, a substância que o animava continua viva, ou seja, a questão da coerência ou não dos conteúdos e situações apresentados nos poemas.

Talvez não se discuta mais se a llíada e a Odisséia foram compostas por vários autores, ou foram o resultado do gênio de um único poeta, mas a questão da coerência ou da inconsistência dos elementos, que se apresentam na narrativa, continua viva. Tanto Finley, Morris ou Snodgrass, cada um a seu modo, aceitam o papel da tradição no processo de composição da épica, porém cada um deles continua argumentando em termos da coerência ou não das formas sociais contidas na épica, de maneira a considerar que um cenário coerente seria a validação de que os poemas retratriam uma sociedade histórica; por sua vez, um cenário incoerente seria indicação que se trata de ficção. Como, então, deveríamos encarar as distintas apreciações do povo contidas na assembléia de Telêmaco e na reunião dos prentendentes. Elas formariam um conjunto conjunto coerente, ou seriam contraditórias entre si?

Pensar como contraditória ou não a maneira como o povo se apresenta descrito nessas duas reuniões depende dos esquemas de referências que utilizamos para compreendê-las. Se considerarmos que o povo é passivo e não possui papel importante no cenário social da épica, a observação dos pretendentes nos aparecerá problemática. A mesma coisa ocorreria no sentido contrário, se considerássemos que na épica o povo teria um papel relevante. Nesse caso, o seu comportamento passivo 
na primeira assembléia é que teria de ser explicado. A idéia de contradição pode surgir mesmo sem apelarmos diretamente para qualquer comparação com possíveis contextos externos ao poema. Ela pode ser obtida nos próprios termos da narrativa, observando neste caso que em uma assembléia ele fora passivo e os pretendentes não o temiam, na outra é descrito como irascível, e que estaria disposto a vingar qualquer malfeito. Essas duas formas de apreciação do povo. A que foi primeiramente apresentada por Liócrito ao dizer que não o temia, mesmo sendo em maior número, e a apresentada por Antínoo, mostrando temor pela sua reação e força, seriam contraditórias ou coerentes nos termos da narrativa?

A questão é da mais alta importância. A idéia de contradição,ou de elementos polares, que formariam um todo coeso têm papel determinante na crítica textual contemporânea. Porém, para as preocupações que animam nosso trabalho não precisamos optar por nenhum desses dois paradigmas, mas apenas explicitá-los, mostrando suas implicações para a análise. Não julgamos necessário escolher nem um, nem outro. Muito pelo contrário, pensamos que o ideal é a utilização de ambos. $\mathrm{O}$ paradigma da contradição permite-nos perceber fissuras e ambigüidades, enquanto o da coerência possibilita-nos visualizá-las em termo de todo orgânico, de sua funcionalidade, tanto ao que se refere aos elementos puramente narrativos, quanto aos da estruturas sociais que servem de pano de fundo. Trata-se de executar um movimento de pêndulo, oscilando entre esses dois paradigmas de análise, percorrendo assim suas diversas possibilidades. 


\section{3 - A assembléia da vingança}

A questão do particular e do coletivo, do papel da assembléia como instância de deliberação e da importância do povo no jogo social também aparecem em torno das discussões que se estabelecem em torno da assembléia Odisséia 24.422, reunida após Odisseu ter matado todos que assediavam sua casa. Nela os parentes das vítimas tomam a palavra e clamam por vingança. Antínoo, o pai de um dos pretendentes, é o primeiro a falar. Vertendo lágrimas, diz que Odisseu perdera os homens e os barcos que levara para longe da pátria, e que agora, tendo retornado, matara muitos e valorosos aqueus. Ele então conclama para que agissem rapidamente, evitando que Odisseu não conseguisse fugir, pois não vingar os seus parentes, diz ele, seria uma vergonha até para as gerações vindouras.

Amigos são terríveis os golpes que aquele homem desferiu nos Aqueus. Quantos valentes ele levou consigo nas naus! Por ele pereceram as naus, e com elas os homens. Regressou e matou outros, a flor da nobreza cefalénea. Mas, vamos, sem esperar que ele se escape à pressa para Pilo ou para a divina Elida, reino dos Epeus, marchemos se não queremos ficar desonrados para sempre, pois cobrir-no-emos de vergonha que a própria posteridade não esquecerá, se os assassinos dos nossos filhos, dos nossos irmãos, permanecerem impunes. Por mim, nunca mais encontraria qualquer gosto pela vida: mais valeria morrer agora mesmo pertencer ao número dos que já não existem! Marchemos, não lhes dêmos tempo de fugir para o mar! ${ }^{36}$

${ }^{36}$ Odisséia 24.422-38. 
Sua fala emocionada arrebata o coração de todos os presentes, porém, vindos da casa de Odisseu, Medonte e o aedo Haliterses aproximam-se deles. Tomando a palavra, Medonte diz, em tom de advertência, que Odisseu não havia operado a vingança sem a ajuda de um deus. Ele mesmo vira um que, sob a aparência de Mentor, ora ficava a encorajá-lo, ora se lançava sobre os pretendentes, derrubando-os pelo salão

Escutai, habitantes de Ítaca. Não foi sem aprovação dos deuses imortais que Ulisses realizou aquelas acções. Eu vi, tal como me estás a ver, um deus imortal que se postava junto de Ulisses e se parecia absolutamente com Mentor. Este deus imortal ora surgia diante de Ulisses e excitava seu ardor, ora, para lançar a perturbação entre os pretendentes, se precipitava através da sala: eles caíam em monte. ${ }^{37}$

A fala de Medonte produz um sentimento de terror. Então Haliterses tomando a palavra, Ihes diz que tudo aquilo que havia ocorrido era culpa deles mesmos por não terem ouvido nem a ele nem a Mentor, quando Ihes aconselharam a fazer os pretendentes cessarem o assédio a Penélope. Ao final, opondo-se a Antínoo, clama para que ninguém marche contra Odisseu, evitando assim encontrarem um mal para eles mesmos

Escutai, habitantes de Ítaca; escutai minha voz. É a vossa apatia, meus amigos, a causa dos males presentes. Não seguíeis os meus conselhos, nem tão-pouco os de Mentor pastor de povos, quando vos exortávamos à por termo à loucura dos vossos filhos, que cedendo a uma fúria funesta, cometeram iniqüidade, devorando os

${ }^{37}$ Odisséia 24.442-9. 
bens, ultrajando a esposa de um homem da mais alta nobreza: pensavam que ele já não voltaria! Agora, possa a minha palavra ser ouvida; segui o conselho que vos dou. Não marcheis contra Ulisses; que cada um de vós receie atrair a desgraça sobre $\mathrm{si}^{38}$

As palavras de Haliterses produzem um alvoroço e divide a assembléia. Uma parte fica com Eupites, a outra prefere seguir Haliterses. Para Finley, o fato de o povo escolher entre um e outro caracterizaria essa assembléia como não formal. Lembremos, para ele a sociedade homérica seria ainda pré-política e a comunidade cívica, em Ítaca, estaria em uma fase de reaparecimento embrionária, "muito ligada à organização familiar e de parentesco", sendo muito mais um instrumento de consulta por parte do rei, do que uma instância de decisão e discussão propriamente dita. Seu Mundo de Ulisses, embora não sendo o micênico, ainda estaria longe da constituição da pólis. Faltar-Ihe-ia o primado do dêmos e a agorá ainda não havia se transformado em um espaço privilegiado de deliberação política. Ela apenas testava os humores da opinião pública, enquanto o conselho de anciãos representaria os sentimentos dos nobres. Assim, essa assembléia não poderia ser formal. Não poderia ser uma reunião do dêmos, pois em seu esquema ele é passivo e aqui, segundo ele, presenciaríamos seus participantes tomando decisão. Portanto, nela, não poderiam estar presentes os homens da plebe, e se estivessem, seria na condição de servidores das famílias nobres e não como membros da comunidade de Ítaca. A prova disso seria que, nessa passagem, Homero jamais utiliza termos como dêmos ou plêthos.

${ }^{38}$ Odisséia 24.454-62. 
A observação de Finley de que o poeta " nos diz claramente" que essa assembléia trata-se de uma reunião aristocrática merece ser analisada mais de perto. Quais seriam as evidências para tal conclusão? O critério validador para justificar a univocidade de sua observação não parece brotar diretamente do trecho citado. Ele afirma que era uma assembléia aristocrática, porém, parece que, mesmo ele, tem dificuldade em operar tal raciocínio, pois necessita criar uma válvula de escape que permita manter sua posição diante da impossibilidade de excluir de maneira objetiva, pela análise textual, a presença dos "do povo" nessa assembléia. Para tanto, afirma que: "mesmo que os homens da plebe estivessem presentes não seria na condição de membros da comunidade de Ítaca, mas como servidores das famílias nobres". Aqui se cria uma situação interessante. Finley considera que o mesmo grupo de pessoas possa estar presente em uma assembléia na condição de membros de uma comunidade e, em outra, na condição de subordinados às casas aristocráticas! Será que as relações de poder, tecidas socialmente no cotidiano, estariam sujeitas a uma modificação tão profunda em sua natureza, pela simples mudança formal do estatuto de uma reunião?

Trabulsi (2001, p.43) observa que Finley, ao considerar o "mundo de Ulisses" como pertencente ao século X e IX, diminui a importância da assembléia homérica e da participação popular nela. Ele, ao analisar essa mesma assembléia, chegou a conclusões bem diferentes. Enquanto para Finley, ela é de natureza aristocrática, para Trabulsi é claramente popular. Segundo ele, o dêmos de Ítaca - palavra que utiliza com o mesmo sentido dado por Finley - acorreu a ela com o coração cheio de 
tristeza $^{39}$. Porém Haliterses, com uma argumentação hábil, conseguiu reverter a situação, infundindo medo neles ao dizer que Odisseu recebia a ajuda de um deus. Como conseqüência de suas palavras, segundo sua tradução, "a maior metade do povo se levantou, mas os outros, permanecendo na sessão, condenavam a opinião de Haliterses e, seguindo Eupites, se lançaram às armas".

A ausência da palavra dêmos ou plethos não serviu de parâmetro conclusivo para que Trabulsi estabelecesse, como fez Finley, o caráter não popular dessa assembléia. Pelo contrário, nela, Trabulsi encontra grande significação popular e a utiliza como "prova" de que a sociedade homérica já possuiria fortes elementos de uma organização políade.

\begin{abstract}
Passagem extraordinária, sob vários pontos de vista: em primeiro lugar, porque mostra o poder limitado do discurso quando este não vai no sentido dos interesses dos destinatários (uma parte do público não muda de opinião); em seguida porque, desta vez pelo menos, não há unanimismo, mas não há exatamente uma cisão. A maneira muito clara de indicar a maior metade de um lado, a menor metade de outro, é já, quase, uma votação. (2001, p.43)(grifo nosso)
\end{abstract}

Como uma mesma passagem pode levar a interpretações tão distintas! E não se trata aqui de detalhe, mas de se considerar se a assembléia em questão era aristocrática ou popular e o grau de intervenção do povo nos processos de decisão! Vamos analisar essa reunião com um pouco mais de detalhes, para que possamos

\footnotetext{
${ }^{39}$ Trabulsi (TRABULSI, 2001, p. 34) também emprega dicotomia aristocracia $\mathrm{x}$ homens comuns para caracterizar a sociedade homérica. Segundo ele, as relações nas assembléias homéricas ocorrem em um quadro hierárquico extremamente polarizado: reis de um lado, povo de outro. Em um esforço de identificar qual seria o vocabulário utilizado para designar o "povo", nos diz que ora ele é a multidão (polús homilos, miríoi), ora o "laós" ou o "dêmos". Segundo ele, "laós" e "dêmos" seriam termos intercambiáveis e designariam um conjunto sem distinções internas.
} 
avaliar melhor o juízo de Finley e de Trabulsi sobre sua natureza social. O verso que informa que uns, decidindo se vingar, seguiram Eupites, e outros, preferindo o apaziguamento, ficaram com Medonte e Haliterses são vagos quanto a definição do es-

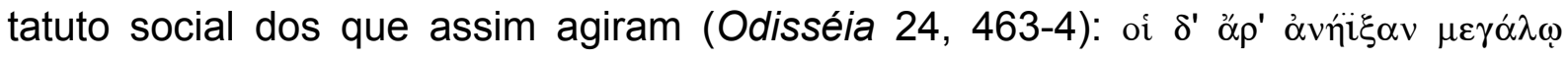

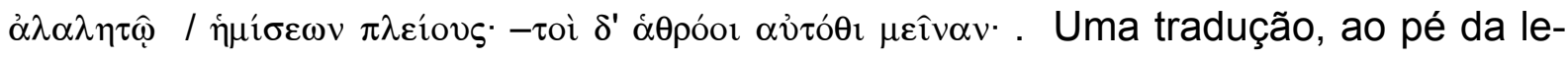
tra, para se preservar a indefinição do verso, seria: "então, uns, mais da metade, se levantaram em grande alarido. Os outros permaneceram cerrados no mesmo lugar." Quem seriam os "uns" e os "outros"

Assim falou, uns, mais da metade, se lançaram com grande alarido, os outros permaceram cerrados no mesmo lugar; pois as palavras não Ihes eram agradáveis... ${ }^{40}$

Em seu comentário sobre essa passagem, Heubeck observa que provavelmente não é possível chegar a uma decisão convincente sobre qual dos dois grupos apóia Haliterses ou Eupites. A quem as palavras de Haliterses não teriam sido agradáveis: aos que se lançaram em grande alarido, ou aos que permaneceram na assembléia? Os pronomes "uns" e "outros" [oi...toí] são indefinidos. A identificação de quem seriam passa pela questão de se saber a quem se refere a oração explicativa "pois as palavras não lhes eram agradáveis". A quem o pronome "Ihes" ( $\sigma \varphi v v)$ estaria relacionado. Heubeck relaciona-o a "uns, mais da metade, se lançaram com grande alarido", considerando assim que a maioria, após ter ouvido as palavras de Haliterses, teria se lançado em direção às armas para lutarem com Eupites contra Odisseu. E os que se deixaram levar pelas palavras de Haliterses teriam permaneci-

${ }^{40}$ Odisséia 24.461-3. 
do na assembléia. Porém, como ele mesmo comenta, um outro entendimento é possível para esse episódio, relacionando o pronome "Ihes" a "os outros permaceram cerrados no mesmo lugar", colocando-se ao lado de Haliterses a maioria que, após ter ouvido suas palavras, teria se lançado com grande alarido em movimento de fuga, enquanto aqueles que se decidiram por apoiar Eupites e lutar contra Odisseu, teriam ficado na assembléia, para logo em seguida se precipitarem em direção às armas.

Heubeck justifica sua opção por considerar que se lançar em grande alarido seria mais condizente com o ato de lutar do que o de permanecer na assembléia. Particularmente preferimos considerar que $o$ ato, que ele qualifica como sendo o mais adequado para o espírito de luta, estaria denotando exatamente o contrário: a idéia de fuga. Outro elemento plausível para justificar nossa posição é que a oração explicativa "pois as palavras não lhes eram agradáveis ao coração" colocada imediatamente após "os outros permaceram cerrados no mesmo lugar" parece estar em relação com esta e não com o "distante" "uns, mais da metade, se lançaram com grande alarido".

Se não é possível estabelecer de maneira conclusiva quem teria recebido o apoio da maior metade, e também não podemos fazê-lo em relação a natureza social dos indivíduos que compunham esses grupos. Seriam membros da aristocracia como quer Finley, ou do povo comum, como advoga Trabulsi?

A cena da formação da assembléia não é esclarecedora nesse sentido. Ela também foi descrita utilizando o pronome "eles" (ót): 
A Fama, rápida mensageira, ia através de toda cidade, contando a morte dos pretendentes e o seu pavoroso destino. Ouvindo esta notícia, os cidadãos ${ }^{41}$ acorriam de toda parte, gritando e gemendo diante da morada de Ulisses: eles levavam os cadáveres e sepultavam-nos com zelo; os mortos de outras cidades foram colocados sobre rápidas naus e pescadores receberam ordem de transportar cada um deles ao seu país. Em seguida os itacenses ${ }^{42}$ dirigiram-se em turba para o local da assembléia, de coração aflito. Quando estavam reunidos em grande número, Levantou-se para falar ${ }^{43}$

O conteúdo dos versos parece indicar que aqueles que se dirigem para a casa de Odisseu têm alguma relação com os pretendentes assassinados, pois "cada um levava e sepultava o cadáver de sua casa"; e que esse mesmo grupo foi o que se dirigiu para a assembléia, já que eles mesmos foram juntos para lá. Tal descrição confirmaria o juízo de Finley de que era uma reunião formada pelos membros das casas aristocráticas cujos parentes morreram na casa de Odisseu?

O recurso de buscar na forma como Eupites, Haliterses e Medonte se dirigem ao povo ali presente também não nos parece conclusivo. Eupites se dirige à assembléia chamando os presentes de "amigos". Tal alusão seria uma evidência de que todos que lá estavam seriam nobres? Medonte e Haliterses dirigem-se aos presentes chamando-os de itacenses. Estariam eles se referindo ao conjunto dos habitantes de Ítaca, ou apenas tomando a parte pelo todo como recurso estilístico?

\footnotetext{
${ }^{41}$ No texto grego não é utilizada nenhuma palavra que pudesse ser vertida por cidadão na função de sujeito do verbo "acorriam". Nele temos apenas a presença do verbo conjugado na terceira pessoal do plural com a supressão do sujeito, dando-lhe um caráter indeterminado. Para melhor manter a indeterminação, melhor seria verter o verso por "Ouvindo esta notícia, acorriam de toda parte".

${ }^{42}$ Aqui estamos diante do mesmo caso apontado na nota número seis. O verbo grego, traduzido por dirigir, não possui como sujeito a palavra "itacenses". Como no caso anterior, ele apenas aparece conjugado na terceira pessoa plural sem que se faça referência determinada de quem seriam esses. ${ }_{43}$ Seriam eles o conjunto da população, ou apenas os parentes dos pretendentes mortos?
} 
Difícil responder, consideramos que o que temos aqui, seguindo um exemplo muito bem dado por Duby, são relações e não fatos

os policiais procuravam fatos, mas encontraram relações. E logo ficaram desorientados: os métodos com que estavam familiarizados já não serviam. Tiveram de fiar-se em seu próprio faro, para não se perderem completamente no imponderável".(1993. p.60)

Estaríamos no campo do imponderável? Não há prova material positiva que ligue a conclusão de Finley com o conteúdo dos versos analisados. O poeta em nenhum momento afirma : nessa assembléia não houve a participação do conjunto da comunidade de Ítaca. Sua prova derradeira é a de que Homero não utiliza a palavra dêmos, ou seja, não faz nenhuma referência explicita "aos de baixo".

O faro de Finley é aguçado, mas quando nos encontramos no terreno do imponderável, ficar se preocupando se um juízo é verdadeiro ou não é uma atitude que consideramos de pouca validade. Além do que, para o desenvolvimento de nossa análise, tal juízo não se faz necessário. Importante para nós é a argumentação com qual ele justifica sua opinião de que assembléia seja aristocrática: "o poeta, diferentemente do que fez na primeira assembléia, não utiliza o vocábulo "dêmos". Nessa passagem, Finley leva ao extremo a prática de analisar as cenas de assembléias projetando-se nelas os significados que se atribui a esse vocábulo. Como ela não está presente, a assembléia não pode ser popular. Em sua argumentação, Finley evidencia que nela o seus participantes tomarem decisão, o que, para ele seria impensável para uma assembléia popular dos séculos XI e X. 
A crítica de Trabulsi também foca a questão dos participantes dessa assembléia tomarem decisão, mas diferentemente de Finley, toma isso como uma evidência de que se trata de um cenário já marcado pela influência da pólis. Para Trabulsi a assembléia conteria fortes elementos políades, pois encontraríamos nela algo muito perto do que chamou ser "quase" uma votação.

Aqui a palavra "quase" exerce um efeito interessante. Ela indica que o ocorrido na assembléia ainda não seria uma votação das que caracterizariam a pólis grega antiga, defendendo assim a sua posição diante dos que possam levantar argumentos no sentido de mostrar a distância que haveria entre os fatos descritos nela e os procedimentos adotados nas assembléias clássicas, mas, ao mesmo tempo, permite analisá-la como se fosse uma. Uma coisa que é "quase" às vezes é, e outras vezes não é. "Quase" não nos proporciona um enunciado preciso. Assim, em que sentido poderíamos afirmar que os acontecimentos relatados nela assemelhar-se-iam a uma votação?

Em seu esquema explicativo, Trabulsi considera que a assembléia homérica caracterizar-se-ia pelo unanimismo, com as decisões sendo tomada por aclamação, ou pela cisão, quando houvesse discordância a respeito do que deveria ser feito. Segundo ele, nessa assembléia, embora os grupos se dividissem, não haveria uma cisão propriamente dita. Mas se nela não houve uma cisão propriamente dita, o que teria ocorrido então? Segundo ele, uma "quase" votação, ou seja, uma votação que não seria uma votação propriamente dita.

Para destacar essa passagem como um momento extraordinário, sua análise

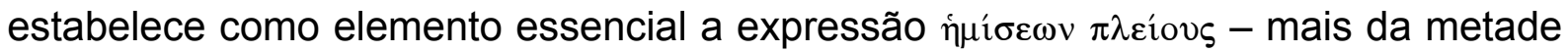
- que seria, segundo ele, uma maneira muito clara de indicar a maioria que confor- 
maria um dos lados, expressando assim já "quase" o princípio de votação. Para ele, o episódio mostra de maneira clara que o povo não é passivo nas assembléias homéricas e que precisa ser mobilizado. As palavras de Eupites, Haliterses e Medonte buscam convencer os presentes para suas finalidades políticas. Como o povo lá presente não se comporta de maneira monolítica, mas expressa capacidade de escolha entre um e outro, conclui que, na épica, as assembléias possuem papel político importante, pois é nela que se o mobiliza para a ação (coisa que Telêmaco tentou na primeira assembléia, mas não conseguiu).

Porém, apesar das diferenças, Finley e Trabulsi apresentam semelhanças importantes na compreensão que possuem do episódio. Ambos consideram que se trata de uma assembléia singular, pois o povo que participa dela toma decisão, escoIhendo por um ou por outro. A questão se encontra em determinar quem é esse povo. Para Finley tratar-se-ia da nobreza, para Trabulsi do povo comum. Vimos, porém, que o texto em si não apresenta definição quanto à origem social das pessoas que participam dela, como então chegaram às suas conclusões?

Finley utiliza dois argumentos, envolvendo tanto a questão da autoria como da composição. Para ele Homero utiliza fórmula "petrificadas pela tradição" que refletiria uma ordem social de 400 anos antes de sua época. O mundo retratado na llíada seria o dos séculos $\mathrm{X}$ e iX, e nele o povo comum não tomaria decisões nas assembléias populares. Segundo Finley, Homero teria mesmo consciência disso e para não deixar dúvidas de que tal assembléia não seria popular não utilizou as palavras dêmos. As questões da autoria, da composição e da atribuição de significados para a palavra dêmos são utilizadas como elementos ativos da interpretação. É por meio delas que Finley qualifica o ato de tomada de decisão ocorrido na assembléia. 
Trabulsi não vê problema em interpretar o episódio como um ato de afirmação do povo comum, que nela toma decisão. A respeito da interpretação de Finley sobre esse episódio, ele comenta:

\begin{abstract}
Alguns autores são levados a minimizar o papel das assembléias homéricas: Finley, na sua explicação sobre o "mundo de Ulisses" como pertencentes aos séculos X e IX, diminui sua importância, seu poder, sua precisão. Eu sei bem que podemos buscar em Homero informações sobre o segundo milênio, apesar de ser um trabalho muito difícil; podemos da mesma forma com ajuda de Finley (o grande advogado desta tese), ver o mundo dos poemas como sendo o dos séculos $\mathrm{X}$ e IX. Eu, quanto a mim, quis examinar os poemas no contexto de sua época de consolidacão e difusão. 44
\end{abstract}

Trabulsi interpreta a passagem contra o pano de fundo do ambiente sóciopolítico que acredita caracterizar o século VIII, momento de conformação da pólis arcaica. Sua metodologia para analisar o poema consiste, como explicitamos anteriormente, em situar a fonte no seu contexto de produção. Como Homero teria composto seus poemas no século VIII, eles teriam que refletir a sua época, portanto nada mais natural para ele que, neles, as assembléias já apresentassem elementos do mundo político que estava se formando.

Se prestarmos atenção ao texto, podemos perceber quais são as características que permitem que o episódio possa ser interpretado assim de maneira tão diversa. O contexto imediato que se apresenta configura-se como indefinido. $\mathrm{O}$ que nós temos nele é que uma quantidade de pessoas acorre à casa de Odisseu para pegar os corpos que jaziam diante dela e que, depois, se dirige à assembléia. Seriam todos nobres, ou formariam o povo comum de Ítaca, ou ambos? A referência a eles é feita por pronomes indefinidos que não permite identificação quanto suas condições 
sociais. O épos se refere ao povo que para lá acorre por "oí" e "toí" que podem ser vertidos por "eles", "uns" ou "outros". E a forma como os que pronunciam os discursos se dirigem ao povo também não nos sinaliza, pelo menos de maneira conclusiva, para a sua condição social. Palavras como "amigos" ou "itacenses" poderiam ser utilizadas como argumentos conclusivos para qualificar o povo presente na assembléia como pertencendo a nobreza?

Temos aqui constituído um problema. O mesmo episódio serve de testemunho para sustentar duas interpretações bem distintas, com cada uma delas enquadrando a sociedade homérica em um modelo diferente. Mas se, quanto à questão da composição social da massa anônima presente nela, o texto se apresenta como indefinido, como conseguiram chegar a conclusões tão precisas?

Suas conclusões são obtidas enquadrando-se a passagem em um contexto que transcende o texto. Seus argumentos pautam-se principalmente pela operação, tão bem explicitada por Trabulsi, de situar os poemas no seu contexto de produção: para Finley, os séculos X e IX; para Trabulsi, o século VIII. Ambos fundamentam seus enquadramentos a partir de interpretações a respeito do processo de composição dos poemas e do papel de Homero nesse processo. Com elas, modelam o episódio que, no tocante às questões que buscam, se apresenta como indefinido. É somente a partir, e dentro de seus enquadramentos, que conseguem interpretá-lo. As evidências internas do texto, de que lançam mão, de forma alguma são conclusivas e acabam, no fundo, exercendo uma função dupla, sustentando um argumento circular. Funcionam como espelho, refletindo, e confirmando, a imagem do contexto a partir do qual se interpreta o episódio. No caso de Finley, a ausência da palavra dêmos e plêthos, funciona como sua prova para confirmar seu juízo. Para Trabulsi, a expressão "mais da metade" significaria a consciência do princípio da votação, o que 
seria suficiente para sustentar sua posição de que a épica retrataria fortes elementos políades, que caracterizariam o mundo grego do século VIII. Seriam a ausência da palavra dêmos e a expressão "mais da metade" elementos fortes suficientes para sustentarem as conclusões a que chegam?

No trabalho de interpretação que executam, eles não partem da interpretação do episódio, para depois atribuir uma determinada época histórica a que ele se referiria. Não tomam o mundo social apresentado na épica como axiomas históricos a revelar uma sociedade realmente existente em algum período que se queira determinar. Mas, pelo contrário, a interpretam a partir de um eixo de referência situado em um contexto externo ao poema. O argumento da ausência da palavra dêmos somente adquire significado diante do pressuposto de que a épica retrataria, a grosso modo, o mundo do século $X$, que não seria nem micênico, nem arcaico. A mesma coisa podemos apontar para o argumento de Trabulsi a respeito da expressão "mais da metade". Como poderia interpretá-la como a manifestação de um elemento políade se não "acreditasse" que Homero estaria retratando a sua própria época, o século VIII. Os argumentos são claramente circulares, auto-confirmadores.

Ambos interpretam o episódio a partir dos eixos de referências externos a ele. Se ela se trata de uma assembléia popular ou aristocrática é uma resposta que necessita do conhecimento prévio do status social dos que nela participam, e de informações da estrutura social que os poemas representariam em seu conjunto. Mas como podemos obter essas respostas, se o episódio se apresenta indefinido em relação a elas? Como podem fixar os séculos $\mathrm{X}$ ou VIII como moldura a partir das quais interpretam o poema, se o poema é a principal fonte para se determinar essa moldura. A llíada e a Odisséia são fontes singulares em seu contexto de produção. 
No caso delas, texto e contexto se confundem, sendo que um não pode ser utilizado para explicar o outro.

A análise histórica da épica homérica não pode recorrer ao contexto externo como ferramenta de interpretação para estabelecer suas linhas de coerência. As questões da autoria e do processo de composição do texto épico são hipóteses que somente podem ser extraídas da análise dos próprios poemas, portanto não podem ser utilizados como chaves de suas interpretações. A velha prática preconizada por Langlois e Seignobos não é cabível de aplicação na análise da épica homérica.

Porém quais seriam as possibilidades de interpretação desse episódio sem se recorrer a contextos externos para corroborar a análise? Calhoun (1984), segundo suas próprias palavras, interpreta as evidências do poema de maneira objetiva e independente de conhecimentos prévios ou de outras fontes, ou seja não recorre a contextos externos ao poema. Para ele, essa assembléia seria uma manifestação definitiva e conclusiva de que Homero, na épica, estaria retratando uma sociedade homogênea, não dividida em classes, uma vez que, segundo ele, os parentes dos pretendentes mortos parecem compreender praticamente a totalidade do povo de Ítaca. Considera que o poeta teria no espírito uma sociedade muito simples, organizada em grupos de parentescos que se acreditavam eles mesmos ser homogêneos. O mundo retratado por Homero caracterizar-se-ia por uma organização tribal simples em que cada pólis seria dominada por um número indeterminado de pequenos reis cujos familiares imediatos partilhavam da sua iminência. O pequeno rei, em um estado tribal, situar-se-ia somente a poucos degraus do patriarca. Ele seria a cabeça de um grupo de parentesco que incluiria pessoas de status econômico e social diversos. O agregado desses grupos de parentescos compreenderia o conjunto da população livre. 
Para ele, o desejo de traçar a evolução da sociedade das primitivas fases homéricas, por uma ordenada sucessão de estágios, da qual a mais recente se aproximaria das instituições da primitiva época histórica, constituir-se-ia em uma desilusão, pois haveria um profundo corte entre Homero e a época histórica. Dessa forma seu argumento se contrapõe ao de Trabulsi, pois questiona a idéia de que a Odisséia representaria um mundo mais próximo da pólis. Mas também se contrapões ao de Finley, pois para ele a sociedade homérica seria homogênea.

Para chegar a conclusão de que a sociedade homérica seria de caráter tribal, Calhoun precisou fixar um elemento como pré-requisito da análise: o argumento de que "praticamente" todo povo de Ítaca seria parente dos pretendentes, resolvendo assim uma das questões que separa Finley e Trabulsi no entendimento dessa assembléia de maneira curiosa. Se para o primeiro, ela é formada somente pelos parentes dos pretendentes e, para o segundo, pelo povo todo, em Calhoun há a junção desses dois argumentos: nessa assembléia estaria o povo todo, que era formado praticamente pelos parentes dos pretendentes mortos. Como ele pode afirmar que tal juízo?

Finley, Trabulsi e Calhoun buscam interpretar a natureza dessa assembléia e o tipo de sociedade que ela representaria pela identificação da origem social dos elementos que a formam. Os argumentos de Finley e Trabulsi, realizados por meio de sua identificação a contextos externos, nos parecem equivocados, mas e o de CaIhoun seria sustentável? Seria plausível, porém não conclusivo. Também na interpretação dele o principal elemento da análise, aquele que estabelece as conexões que permitem a interpretação é frágil demais: todo o povo presente na assembléia de alguma forma estaria relacionado aos pretendentes? 
Se a observação de Calhoun estiver corretar, como deveríamos entender as palavras de Mentor, na assembléia de Telêmaco, ao afirmar que os pretendentes eram poucos e o resto de dêmos muitos? O resto do dêmos, a que Mentor se refere, também estaria presente nesta assembléia? Os versos indicam que sim, pois, ao comentar as palavras de Haliterses, diz que a causa da morte dos pretendentes seria eles mesmos, pois não ouviram as advertências que lhes foram feitas quando da assembléia de Telêmaco. Mas se os parentes dos pretendentes formam quase a totalidade da comunidade de Ítaca, Mentor, na assembléia de Telêmaco estaria pedindo a eles para contê-los? Nesse caso a divisão que estaria operando, em sua fala, seria entre os pretendentes e seus parentes?

Podemos obter ajuda, para o equacionamento dessas questões, pela análise do tema que se apresenta como ponto de discussão na assembléia: o tema da vingança. Ela nos proporciona a possibilidade de investigar o texto épico a partir de suas conexões internas, abrindo uma frente de argumentação alternativa, geralmente fecunda, que possibilita evidenciar aspectos que não podem ser desvelados pelos estudos que a contrapõe a um contexto externo pré-definido.

Nesta assembléia o que se discute é a vingança que deve ser operada contra Odisseu, pelas mortes que ocasionou. O tema do assassinato é um dos mais recorrentes da épica homérica. Na Odisséia, o caso mais ilustre é o de Agamêmnon, morto por Egisto e Clitemnestra, quando mal tinha chegado a sua casa. Sua morte foi vingada por Orestes, seu filho, matando Egisto e sua própria mãe. A narrativa do assassinato de Agamêmnom circunscreve-se à esfera familiar. Egisto, o assassino, era seu primo. Orestes seu vingador, seu filho. 
Outro caso de assassinato, narrado na Odisséia, é o que foi praticado por Teoclímeno. Telêmaco, retornando da viagem que fizera em busca de informações sobre seu pai, deparou-se com ele, que, fugindo, Ihe pedira abrigo. Ele matara um ho-

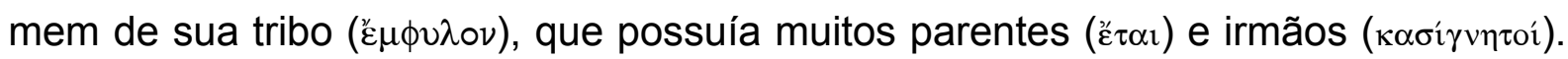
Fugia de sua pátria para escapar à morte.

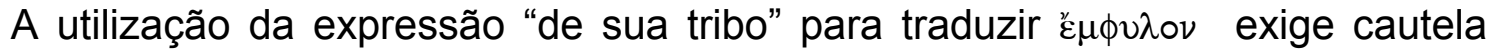
com o significado de "tribo". Tanto o vocábulo grego фú̃ov , como a palavra "tribo" está no centro do debate complexo que se trava em torno das questões que caracterizariam as organizações sociais primitivas. $\Theta v \hat{\lambda}$ ov com certeza trata-se de uma forma associativa, mas é muito difícil precisar sua natureza. A questão principal encontra-se em determinar em que medida ela se assentaria em relações de parentescos ou não, e qual seria sua abrangência. Estamos diante de questões polêmicas já discutidas anteriormente. $\mathrm{O}$ interessante nessa passagem é que o homem morto por

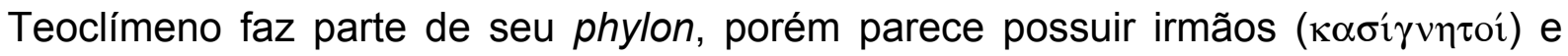

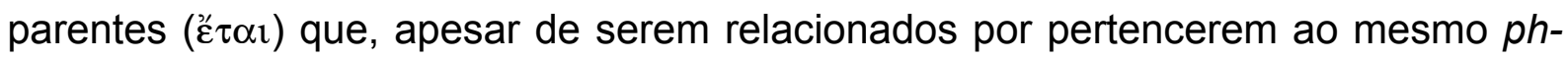
ylon, de alguma forma se diferenciam. Em que medida a parentela de Teoclímeno se diferenciaria da do morto? Ambos teriam parentes diferentes? Um phylon seria uma associação constituída de grupos de parentescos que aparecem como distintos? Questões polêmicas que não podem ser resolvidas pela pré-atribuição de significados para a palavra phylon, pois com isso estaríamos cometendo o mesmo erro que comentamos a respeito da prática dos que lançam mão de fixar significados precisos para dêmos e laós.

Na llíada, temos o caso de Tlepólemos, filho de Héracles que, matando seu tioavô materno, teve que fugir para escapar das ameaças dos outros filhos e netos de 
seu pai. Seria esse um caso semelhante ao de Teoclímeno $?^{44}$ Epigeu busca guarida junto a Aquiles por ter matado um primo ${ }^{45}$. Medonte fugiu por ter matado um parente de sua madrasta ${ }^{46}$. Licofone vivia junto a Ajax por ter matado um homem na Cítera ${ }^{47}$. E Pátroclo foi levado por seu pai até Peleu, por ter matado um rapaz involuntariamente, quando jovem ${ }^{48}$.

Os casos de assassinato relatados na épica mostram que o assassino sofre a ameaça de vingança por partes dos parentes dos mortos. Como observa Nestor, em um tom proverbial: "é bom para um homem assassinado ter deixado um filho homem, pois esse vinga a morte do pai” ${ }^{49}$. Essas palavras foram ditas à Telêmaci, ao referir-se a Menelau, irmão de Agamêmnom, observando que esse nada pôde fazer a respeito do assassinato de seu irmão, pois se encontrava ausente, errando por sete anos pelos lados do Egito, porém se tivesse voltado e deparado com Egisto vivo, ele o mataria ${ }^{50}$. Assim a morte Agamêmnom teve de esperar por sete anos, até que seu filho crescesse, para ser vingada. Na épica, a vingança de um assassinato aparece como ação da alçada dos parentes dos mortos. Como diz Odisseu, mesmo se forem em número reduzido, um assassino deve temer a vingança dos parentes da vítima e buscar escapar à morte pela fuga ${ }^{51}$.

Na llíada480-3, a entrada de Príamo na tenda de Aquiles para pedir o resgate do corpo de seu filho é comparada com a cena de alguém que, fugindo da pátria, busca abrigo em uma mansão nos estrangeiro:

\footnotetext{
${ }^{44}$ Odisséia 2.653-70.

45 Ilíada16.572-5.

46 Ilíada13.694-7.

47 Ilíada15.432.

48 Ilíada23.85-8.

49 Odisséia 3.198.

50 Odisséia 3.256-61.

51 Odisséia 23.118-23.
} 
Sem pelos outros ser visto, entra o grande monarca, e de Aquiles aproximando-se, abraça-lhes o joelho e beija as terríveis mãos homicidas, que muitos dos filhos the havia matado. Como se dá quando algum criminoso exilado da pátria busca, vencido da angústia, refúgio em mansão opulenta de potentado estrangeiro, deixando os presentes atônitos ${ }^{52}$.

A opção para um assassino não ter que fugir seria pagar o resgate, como podemos ver nas palavras de Ájax a Aquiles, ao afirmar que é comum se aceitar um resgate por um filho ou irmão assassinado.

Homem cruel que não presa a amizade dos fidos consócios, essa com que o distinguíamos, junto de nossos navios! Sem compaixão! É comum, aceitar-se o resgate, até mesmo pelo assassínio do irmão, pela morte do filho querido. Fica o ofensor no país, quando a multa adequada se acorda, pois o ofendido refreia no peito a paixão excruciante com o receber os presentes. ${ }^{53}$

A morte, o exílio ou o pagamento de resgate são as opções que a sociedade configurada na épica oferece a Odisseu por ter matado tantos homens. Porém recusando a três, ele opta por enfrentar os parentes de suas vítimas. Na "Assembléia da Vingança", temos o início da reação dos ofendidos, que buscam reunir forças contra Odisseu. Eles têm em Eupites seu representante. Em sua fala emocionada começa evidenciando os atos de Odisseu, colocando-o como um criminoso que muitos males causara aos aqueus:

52 llíada24.477-82.

53 Ilíada9.632-6. 
Amigos, que enormes desgraças tem esse homem causado aos aqueus; primeiro levou embarcados grande número de fidalgos e, além de perder os bojudos barcos, perdeu os homens; depois, voltando, assassinou os mais nobres dos cefalenos.

Eupites expõe a gravidade das ações de Odisseu. Ele, que iniciou sua fala dirigindo-se aos presentes como "amigos", dizendo que Odisseu causara muitos sofrimentos aos "aqueus", logo particulariza a questão exclamando que seria grande vergonha se não vingassem a morte dos filhos e dos irmãos. A lógica do discurso pronunciado por Eupites anula a questão de que se ele estaria falando a um público composto basicamente pelos parentes dos pretendentes mortos ou não. Aludindo à perda do exército que levou à Tróia, ele situa os atos danosos de Odisseu em uma esfera mais ampla, não restringindo somente ao assassinato dos pretendentes.

A perda do exército mais a morte dos pretendentes, oriundos das famílias mais nobres de Ítaca, deve ser um evento que se relaciona a grande parte da comunidade, senão toda ela. Ele quer perseguir Odisseu pelo conjunto da obra e não somente pelo assassinato dos pretendentes. Mas, se Eupites envolve o conjunto da comunidade, em sua mobilização contra Odisseu, seu discurso se desenvolve no quadro traçado pelo tema do assassinato, enquadrando a vingança na esfera da ação familiar: "devemos vingar a morte de nossos filhos e irmãos" é o que ele diz.

Em sua exortação, ele fala como se esperasse que a atitude natural de Odisseu fosse a fuga:

Eia, porém, marchemos antes que ele se vá correndo a Pilos ou à divina Élis, onde os epeus detêm o poder [...] Porém, vamos, não demos tempo para a travessia. 
As suas palavras comovem a todos. Levantarem-se contra Odisseu, seria o esperado. As perdas humanas que Eupites Ihe imputa são enormes, justificando a identificação que opera, em seu discurso, entre os cefalêneos como um todo e os parentes dos mortos. Eles eram maioria, e Odisseu estaria sozinho, não teriam assim o que temer. Porém, em meio a eles, Medonte toma a palavra e diz que Odisseu, ao matar os pretendentes, recebera a ajuda de um deus. Depois, Haliterses diz a eles que a culpa daquilo tudo ter acontecido era deles mesmos, pois não deram ouvidos às advertência que thes foram feita.

As palavras de Medonte e Haliterses, como vimos, provocam uma debandada de parte dos assembleiados, que se recusam a perseguir Odisseu, temendo uma sorte igual aos dos pretendentes. Embora fossem muitos, Odisseu contava com a ajuda de um deus! Esses que debandaram fariam parte da parentela dos que morreram, mas que por temerem a própria morte não vingam seus mortos, ou seriam membros da comunidade sem ligações de parentescos com os pretendentes?

O conteúdo dos discuros proferidos nessa assembléia, insere os presentes no âmbito das relações de parentescos, identificando as vítimas de Odisseu com o conjunto da sociedade. Entre os pretendentes se diz estar presente filhos oriundos de todas as famílias que senhoreiam em Ítaca. Agora, de que forma poderíamos entender o comportamento dos seus participantes: uns debandando, outros ficando para a luta? Em que medida poderíamos considerar esse acontecimento como um processo que habilitaria classificar a assembléia em questão como extraordinária em relação às outras que se apresentam na épica?

Consideramos difícil pensar os acontecimentos descritos nela em termos de uma votação, como faz Trabulsi, pois não houve uma. Como não consideramos 
também a idéia de cisão conveniente. Descartamos essas duas possibilidades pelo mesmo motivo: elas envolvem a constituição de um corpo coletivo pensado em termo de unidade, pelo menos ao que se refira a essa questão. O procedimento da votação somente tem sentido se for pensado como forma de se obter uma ação conjunta, na qual a minoria se obriga a acompanhar a decisão da maioria, e não é esse cenário que se configura na "Assembléia da Vingança". Os eventos nela descritos não podem ser caracterizados por uma consulta ao povo para se saber qual seria a sua vontade para traduzí-la em ação política, em nome do todo. Estamos muito longe das assembléias atenienses descritas por Tucídides, em que nelas o povo decidia as ações militares da cidade pela maioria. O episódio em que os atenienses deliberaram a respeito das punições que infringiriam aos mitilenos, após terem sufocado um movimento de revolta entre eles, é ilustrativo.

Eles haviam decidido, em uma assembléia, matar todos os homens adultos de Mitilene e escravizar suas esposas e filhos. Porém se arrependeram e resolveram deliberar novamente sobre o assunto. Nesta nova assembléia, foram apresentadas opiniões antagônicas, umas defendendo a manutenção da punição, outras a sua moderação. Os atenienses ficaram divididos a respeito da questão, porém em uma votação quase igual prevaleceu a opinião da moderação, e a ordem de execução foi suspensa pela assembléia.

Esse é um cenário em que a assembléia toma uma decisão que orienta a ação da cidade, obrigando seus cidadãos a acatá-la. Não se trata de uma decisão que seja facultativa seguí-la ou não . A suspensão da execução dos mitilenos não pode ser desobedecida pelas forças militares subordinadas aos decretos da assembléia. O cenário da "Assembléia da Vingança" nos parece bem diferente. Nela, pelo resultado, os presentes não se comportam como um corpo coletivo, decidindo a respeito 
de uma ação que deveria ser tomada conjuntamente por todos, mesmo pela minoria que fosse vencida pelo voto. Os seus membros simplesmente decidem por cada uma das opções. Poderíamos nesse caso falar em cisão? Consideramos que também não. Não ocorre aqui a divisão de um corpo coletivo que necessariamente levaria a um processo de disputa, motivando a ruptura política por meio da guerra civllíada A minoria não segue a posição da maioria, mas também não se volta contra ela, nem é perseguida por isso. Uma parte simplesmente debanda, não apoiando Eupites, mas também deixando Odisseu sozinho. Seria isso um cenário que se caracterizaria como uma "quase" votação, definindo essa assembléia com elementos "quase" políades? Como poderíamos interpretar esse episódio?

Nela a opção de vingar ou não os mortos é particular, condição que se encontra de acordo com a configuração do tema do assassinato, tanto na Odisséia como na llíada. É o valor e o sentimento da honra ferida que impele à vingança. Como nos diz Eupites, ele preferiria morrer a não vingar seus mortos, pois a desonra que the acometeria seria tão grande que atingiria até as gerações vindouras. Porém, o caso assume uma dimensão coletiva, pois a quantidade de oîkos atingida lhe confere um caráter público, que ao ser tratado na assembléia assume um aspecto comunitário, embora ele não perca o caráter de vingança particular, que deva ser empreendida pelo oîkos ofendido ao seu agressor. Estamos diante de um conflito, tornado público devido a sua extensão, mas que é percebido como de ordem privado pela narrativa. Estamos longe de uma situação "políade" e, no fundo, não importa saber se nessa assembléia estariam presentes somente membros das famílias vitimadas, ou não, pois, se levarmos em consideração o "tema do assassinato", vemos que se há um código de honra impulsionando a família de um homem assassinado a vingá-lo, também não há nada que a obrigue. Embora, para a conduta heróica, essa fosse 
uma prática desonrosa, o que justificaria praticamente a sua ausência no esquema formular que compõe o tema. Como alguém mais fraco poderia vingar a morte de um parente na pessoa de alguém que lhe fosse mais forte, possuindo uma dignidade heróica que Ihe fosse superior. Não seria esse o caso de Héracles que matou fulano, e ninguém apareceu para vingá-lo. Não seria esse o caso dos que debandaram na "Assembléia da Vingança", reconhecendo, por esse ato, uma estatura heróica superior a deles. Se Eupites, com suas palavras, expressa o ideal heróico em sua máxima extensão, preferindo morrer a não ir atrás de Odisseu, os outros parecem ter pautado suas atitudes por um conjunto de valores que representaria um plano não heróico da percepção da realidade: preferiram viver, mesmo que desonrados.

Como a parte que optou em ir atrás de Odisseu e a que preferiu fugir não estavam ligadas por laços indissolúveis nessa questão, pois a vingança é uma empresa privada, cada uma fez o que quis. Nada aqui sugere a constituição da assembléia marcando um espaço público de reunião de uma coletividade que se visse como um corpo coletivo único, mas o de uma coletividade, que se reúne em um espaço comunitário sim, mas que se vê como uma reunião frousmante amalgamada, longe de se constituir em um espaço político, em que a maioria na assembléia representaria a vontade da comunidade, que deveria ser seguida por todos.

Agora estamos em condições de verificar em que medida essa assembléia se distingue das outras, a ponto de Finley chegar a afirmar que ela não seria uma reunião formal e Trabulsi classificá-la como extraordinária. Para tanto, vimos que eles se apegam ao fato de que o povo presente nela toma decisão, porém também verificamos que essa tomada de decisão, quando interpretada a partir do "tema do assassinato", está muito longe de se configurar como um processo deliberativo da comunidade representada na assembléia. A escolha entre vingar ou não a morte dos 
pretendentes não aparece como ação da comunidade como um todo. Os que julgam assim necessário proceder vão contra Odisseu, os que não, simplesmente debandam.

Não é possível determinar como esse processo de escolha teria ocorrido na esfera das famílias envolvidas. Se o grupo que debandou era formado por famílias inteiras, ou se a divisão teria se operado no interior de cada grupo familiar, com alguns seguindo Eupites outros não. $O$ texto não fornece elementos para que possamos determinar se a escolha teria ocorrido na esfera do exercício de uma opção individual ou familiar, com o chefe do oîkos tomando uma decisão e todos os seus membros seguindo-na. Porém uma questão nos parece clara: nessa assembléia, os grupos presentes nela estão frouxamente amalgamados. A vingança é uma empresa de alçada familiar (oîkos) e não pública (dêmion) 
5- CONCLUSÃO: A CENA Final 


\section{5 - Conclusão: A Cena Final}

Heubeck aponta uma estreita relação entre as assembléias de "Telêmaco" e a da "Vingança". Segundo ele, a parte final do último livro seria devotada à confrontação e à reconciliação com os parentes dos pretendentes. Desde o início, a ação não estaria direcionada somente para o retorno do herói, a sua vingança e a reunião com seus familiares, mas também para a restauração da ordem em Ítaca. Nesse sentido, não haveria dúvidas de que a "Assembléia da Vingança" seria uma contrapartida estrutural da "Assembléia de Telêmaco".

Em seu plano de vingança, Odisseu pontua repetidamente que ela motivaria retaliação por parte dos parentes dos pretendentes. Em uma conversa com Atena, expressa a preocupação de como poderia dominar os pretendentes, que sempre estavam reunidos em grande número. E mesmo que pudesse matá-los, aonde iria se refugiar? ${ }^{1}$. Após ter consumado a vingança, Odisseu, ao se preparar para sair de seu solar, aconselha Penélope a ficar em seu quarto, pois seria inevitável que a notícia da morte dos pretendentes se espalhasse. O seu recado é claro: proteja-se pois os parentes ofendidos buscarão vingança ${ }^{2}$.

A extensão da vingança abrangeria toda comunidade, porém Odisseu era o rei, como então, depois dela, seria promoveria a reconciliação necessária entre ele e seu povo? De que maneira seria possível evitar a vingança por parte dos parentes

\footnotetext{
${ }^{1}$ Od.20.39-43.

${ }^{2}$ Od.23.361-5.
} 
ofendidos? Segundo Heubeck (Ibid.), é por meio dessas duas assembléias que o épos abre as condições para que a paz possa ser restabelecida.

Na primeira assembléia, toda comunidade é envolvida na questão, pois, diante dos malfeitos dos pretendentes, ela deveria interceder, fazendo-os cessar. Na segunda, Haliterses é bem claro: a culpa de tudo aquilo era da própria comunidade que não atendeu aos apelos de Telêmaco, quando este convocou a assembléia e solicitou apoio de todos eles contra os pretendentes. Agora a vingança divina se operava. E seria melhor, para que um mal maior não sobreviesse a eles, não marcharem contra Odisseu.

Por meio das duas assembléias a narrativa deixa claro: a vingança de Odisseu fora justa, o que havia colocado os deuses ao seu lado, não cabendo aos parentes vingarem seus mortos, pois, agindo dessa maneira, iriam buscar a própria morte. Mas Eupites não se preocupa com as conseqüências. Ele quer a vingança. Não operá-la seria desonroso. Para ele, seria preferível a morte, a viver de cabeça baixa por tal infâmia, então ele lidera os que o seguem contra Odisseu.

Na cena final da Odisséia, é narrado esse conflito. De um lado, estão os parentes ofendidos pelas mortes de seus entes queridos, de outro, Odisseu e seu pequeno grupo. Diante da situação, Atena, lá no Olimpo, expressa preocupação e fala ao seu pai ${ }^{3}$

Pai nosso, filho de Crono, supremo senhor, responde a minha pergunta; que desígnios escondes no íntimo? Acaso levarás por adiante 
essa guerra funesta, essa terrível refrega? Ou firmarás amizade entre as partes?

A vingança de Odisseu havia atraído mais vingança. Agora eram os parentes dos pretendentes que buscavam a restauração da honra. Atena preocupa-se, pois considera que é necessário evitar a guerra entre as partes. Zeus responde dizendo que o plano de vingança era obra da própria deusa, e que ela deveria agir como bem quisesse, porém conviria que Odisseu reinasse para sempre e que a morte dos pretendentes fosse esquecida, para que assim a paz e a riqueza se estabelecesse. Para tanto seria necessário que voltassem a se estimar mutuamente como outrora.

Minha filha, por que me perguntas e indaga isso? Não concebeste tu mesma o plano segundo o qual, regressando, Odisseu haveria de vingar-se daquela gente? Faze como queiras; dir-te-ei, embora o que convém. Agora que o divino Odisseu tomou, afinal, vingança dos pretendentes, que, depois de solenizarem um juramento fidedigno, reine ele toda vida e nós, por nossa vez, releguemos ao esquecimento o morticínio dos filhos e irmãos, para que se estime mutuamente como antes e sobeje riqueza e paz. ${ }^{4}$

Após as palavras de seu pai, Atena dirige-se para o solar de Laertes, onde a batalha já se preparava, e na figura de Mentor se alinha com seus protegidos. Com sua ajuda, Laertes, mesmo idoso, arremete sua lança, atingindo e matando Eupites, o líder do grupo inimigo, que anteriormente afirmará que preferiria morrer, a viver sem vingar seu filho. Atena concede-lhe o pedido! Em seguida, Odisseu e Telêmaco arremetem-se contra as fileiras inimigas, e teriam matado a todos se a deusa não interviesse

\footnotetext{
${ }^{4}$ Od.24.478-86.
} 
Sustai, Itacenses, a penosa batalha, para que vós possais separar quanto antes sem derramamento de sangue. ${ }^{5}$

Apavorados, os que buscavam vingança contra Odisseu largam as armas, dãoIhe as costas, e correm para a cidade. Mas Odisseu, tomado pela fúria, exacerba. Querendo a morte de muitos, ultrapassa os limites aquiescidos por Zeus, e persegue os fugitivos. Nesse momento, então, Zeus envia um sinal. Atena, entendendo a vontade de seu pai, contém o herói

Filho de Laertes, progênie de Zeus, engenhoso Odisseu, sustém , cessa o combate duma guerra funesta a ambos os lados, se não queres que Zeus, filho de Crono, de voz longe ouvida, se agaste contigo. ${ }^{6}$

Odisseu não deveria prolongar a luta além das necessidades de restabelecimento de sua honra. Há um limite para o exercício de sua vingança que, ultrapassado, o levaria a incorrer em erro. Então, ele prontamente houve o conselho da deusa, e um pacto é firmado entre os dois lados, restabelecendo a paz. Os últimos versos da Odisséia são destinados à celebração desse tema

Palas Atena, filha de Zeus, senhor da Égide, sob o aspecto de Mentor no corpo e na voz, selou entre ambas as partes um juramento de paz para o futuro ${ }^{7}$.

\footnotetext{
${ }^{5}$ Od.24.531-2.

${ }^{6}$ Od.24.542-44.

${ }^{7}$ Od.24.545-8.
} 
A Odisséia, em seu final, apresenta uma narrativa que confronta o cenário de uma guerra, que não seria boa para nenhum dos lados, com o cenário de uma vida de paz e riqueza, marcado pela amizade (philia), que deveria caracterizar a relação de Odisseu com seu povo. Para tanto, os parentes dos pretendentes deveriam esquecer os seus mortos, e Odisseu, por seu lado, deveria refrear sua cólera. A cena final da Odisséia é uma celebração da paz.

Para Heubeck, agindo assim, Zeus e sua filha substituem o velho sistema de justiça patriarcal, fundamentado no direito à vingança de sangue. Em seu lugar teriam estabelecido uma nova ordem moral, baseada na justiça guardada e garantida pelos deuses. Seria a Odisséia uma evidência de alterações profundas, que estariam ocorrendo na sociedade grega, refletindo a alteração do pacto associativo ,que caracterizaria as sociedades patriarcais, para uma forma associativa em que o direito vingança estivesse sendo limitado?

Segundo Finley (Ibid., p. 71), historicamente haveria uma relação inversa entre a extensão da noção de crime, concebido como um delito público, e a autoridade do grupo de parentesco, sendo que se poderia mesmo descrever o desenvolvimento da idéia de crime e de lei criminal como a história do enfraquecimento da onipotência familiar dos primeiros tempos. Finley deixa explícito em seu comentário, o que Heubeck deixa subtendido: a relação que ele opera entre o direito de vingança existente nas sociedades patriarcais, e a sua limitação nas sociedades estatais.

A conclusão de Heubeck a respeito das significações políticas do conflito estabelecido entre Odisseu e os pretendentes apóia-se em pressupostos que não podem ser deixados de lado na sua avaliação. A sua afirmação de que na Odisséia se opera a substituição do velho sistema de justiça patriarcal, apoiado no direito à vingan- 
ça, por um modelo de justiça mantido e garantido pelos deuses nos parece precipitada. Telêmaco, na primeira assembléia, fala exatamente sobre a vingança da qual os pretendentes seriam vítimas, que, por sinal, teria complacência divina, pela justiça que sua causa guardava. Atena participa ativamente no banho de sangue promovido por Odisseu, sendo que Zeus apenas intervém, fazendo-o cessar, quando ele transpõe os limites que considerava adequado. Para aceitarmos conclusão de Heubeck, teríamos de separar as mortes provocadas por Atena e Odisseu, da intervenção final de Zeus, considerando que suas atitudes seriam parte do modelo patriarcal, e a intervenção de Zeus, no novo modelo que se estabelecia. A paz obtida por esse meio, quebrando o ciclo de violência, que de outra forma não teria fim, refletiria um novo arranjo político.

Não nos parece que haja aqui a substituição de um modelo de justiça marcado pela vingança de sangue, por uma garantida pela ordem divina. $\mathrm{O}$ direito de vingança é relacionado por Telêmaco, desde o primeiro momento de suas falas, à esfera divina. Ele diz ao povo que eles deveriam temer a cólera dos deuses pelos malfeitos dos pretendentes, salvo se tivessem sido ofendido por Odisseu, e agora estivessem em desforra $\left(\dot{\alpha} \pi \circ \tau^{\prime} v \omega\right)$. Como esse não era o caso, e os pretendentes se recusam abandonar sua casa, Telêmaco ameaça-lhes invocar os deuses eternos, pois assim, quem sabe, Zeus consentisse ações punitivas que os fizessem perecer em seu solar, sem serem vingados (vímoเvoí).

Não nos parece que haveria um modelo patriarcal de justiça, baseada na vingança de sangue, e um outro baseado na garantia divina, mas sim que a vingança de sangue era garantida e patrocinada pelos próprios deuses, desde que a causa 
fosse justa. A causa de Odisseu era justa e ele mesmo, momentos antes de iniciar a matança, faz o relato das acusações que pesavam sobre os pretendentes ${ }^{8}$

Ah! Cães, julgáveis que eu nunca mais voltaria da terra troiana à pátria, e assim pilháveis a minha casa; obrigáveis as minhas servas a dormir convosco e, estando eu vivo, requestáveis a minha mulher, sem temer os deuses que habitam o vasto céu nem o desforço que um dia os homens os podiam tirar de vós! E agora a morte está suspensa sobre todas as suas cabeças!

Eurímaco, tentando salvar a própria pele, aproveitando que Antínoo já se encontrava morto, estendido pelo chão, joga toda a culpa nele, dizendo ter sido ele quem os havia instigado a tudo isso. Ele diz a Odisseu que Antínoo queria o casamento com Penélope para reinar sobre o dêmos de Ítaca, e pede para que ele os poupe. Em troca pagariam justa reparação por tudo o que fora consumido em sua casa. ${ }^{9} \mathrm{~A}$ isso, Odisseu responde-lhe ${ }^{10}$ :

Eurímaco, se me désseis como reparação todos os bens de vossos antepassados, se a todos os que possuí agora acrescentásseis ainda outras riquezas, mesmo assim eu não suspenderia o massacre com meu braço antes de ter feito pagar aos pretendentes todas as suas insolências.

Odisseu não aceita compensação em bens pela reparação de sua honra, então executa sua vingança e os mata. Porém, a morte de seus entes queridos levou os parentes dos pretendentes a buscarem vingança. No afã de mobilizar o povo, Eupi-

\footnotetext{
${ }^{8}$ Od.22.35-41.

${ }^{9}$ Od.22.45-59.

${ }^{10}$ Od.22.61-4.
} 
tes também fez um relato das faltas que Odisseu teria cometido. Ele diz que, Odisseu havia perdido os homens que levara com ele para Tróia e agora, voltando, matara muitos dos filhos dos aqueus. Na ótica de Eupites são mortes que devem ser retaliadas, caso seus parentes não queiram sofrer a desonra de deixarem seus mortos sem vingança. Porém a narrativa parece inocentar Odisseu dessas duas acusações.

Quanto à morte dos homens que levara à Tróia, o próprio poeta, na figura do narrador, ao fazer a invocação às Musas, diz que eles morreram por culpa própria, pois não ouviram as advertências de que não deveriam tocar no rebanho de Hélio. Sobre a morte dos pretendentes, Haliterses diz a assembléia que a culpa de tudo que havia acontecido era deles mesmos, pois não ouviram as advertências que lhes foram feitas por Telêmaco. A cólera dos deuses aos malfeitos dos pretendentes havia operado a vingança. Agora, eles se encontravam mortos, sem que os deuses consentissem a reparação. Tentar vingá-los seria buscar a própria morte. Então, parte da assembléia recua, parte avança contra Odisseu.

Pelo código de honra apresentado por Eupites, vislumbramos um sistema em que vingança atrai vingança em um ciclo que, pelo menos enquanto os lados envolvidos apresentassem condição para reagir, seria ininterrupto. Odisseu matara os pretendentes, e agora os seus parentes pretendiam matá-lo. Nesse aspecto, as duas assembléias da Odisséia contrapõem a vingança justa, consentida pelos deuses, e a injusta, condenada ao fracasso, pois não conta com o apoio divino. Na vingança justa, que Odisseu pratica, os ofensores morrem sem que haja reparação pelas suas mortes, restabelecendo assim a paz e o equilíbrio rompido. A idéia da justa vingança de sangue, garantida pelos deuses, opera assim como um importante instrumento no controle das tensões sociais que perturbam o equilíbrio da vida em comunidade. 
Por meio dela, Telêmaco busca inibir o comportamento dos pretendentes. Uma vez executada, suas vítimas morrem inultas.

No conflito que se estabeleceu, a comunidade foi chamada a intervir. Como poderíamos interpretar o seu papel nesse jogo de tensões? Por que o povo não se manifesta na primeira assembléia? Segundo Finley (Ibid., p. 88) porque o dêmos restou neutro e desinteressado diante da questão. Trabulsi diz explicitamente se tratar de uma questão particular, portanto não seria da alçada do povo participar dela. Para Calhoun (Ibid.), embora não se manifeste explicitamente sobre a primeira assembléia, poderíamos inferir, a partir de seus comentários sobre a segunda assembléia, que o povo não se manifesta, pois todos estariam ligados de alguma forma por relações de parentescos aos pretendentes. As duas opções nos levariam a problemas para interpretar a posição do "povo" aludida na "Reunião dos Pretendentes", onde se afirma que eles já não contavam com o apoio popular, e que se caso a tentativa de assassinato que operaram contra Telêmaco viesse à tona, facilmente, ele obteria o apoio da comunidade para expulsá-los de Ítaca.

Se optássemos pela interpretação de Trabulsi, poderíamos afirmar que o assédio dos pretendentes à casa de Odisseu fora entendido pelo povo como uma questão de ordem particular, e o assassinato de Telêmaco seria entendida como uma questão pública. Porém para aceitarmos tal hipótese teríamos que considerar as palavras de Telêmaco e Mentor, responsabilizando a todos pelo assédio dos pretendentes, como puro jogo retórico, que não teria obtido sucesso em granjear apoio da comunidade. Telêmaco ao apresentar a questão de forma a mostrar suas dimensões coletivas estaria tentando obter apoio dos presentes com um argumento que não condizia com a situação, o que teria levado a assembléia a não dar atenção aos seus queixumes? Para dar crédito à interpretação que identifica o silêncio do povo 
na "Assembléia de Telêmaco" como conseqüência de que nela se discute um assunto particular, teríamos de desconsiderar as palavras de Telêmaco, Haliterse e Mentor, que a alça para a esfera coletiva. Seria esse o motivo de Finley afirmar de forma categórica que "Telêmaco não se dirige uma só vez ao povo"?

Em seu discurso, embora Telêmaco inicie-o afirmando se tratar de uma questão de sua própria casa, ele rapidamente envolve a comunidade toda no conflito. Os malfeitos dos pretendentes deveriam provocar indignação a todos, motivando assim uma censura aos pretendentes, coibindo-os. Caso assim não procedesse somente poderia ser por conivência aos atos vis, por meio dos quais os pretendentes destruíam sua casa. O discurso de Telêmaco não apresenta espaço para a neutralidade: ou o povo apóia sua causa, que é justa, ou então é conivente, portanto também passível de punição divina, como os pretendentes. Mentor censura os laói e o resto do dêmos por não agirem contra os pretendentes, alegando que esses deviam lealdade ao bom rei que Odisseu sempre fora.

O que é justo e o que é justo ou não esta sendo determinado pelo princípio da reciprocidade. Telêmaco, anteriormente, já expressara reconhecimento de que seria aceitável a ação dos pretendentes, caso seu pai houvesse praticado coisas más. Agora, Mentor observa que, embora Odisseu tenha sido um bom rei, ninguém dos laói, naquele momento, se lembrava dele. Odisseu fora esquecido, e o povo não the oferecia a contrapartida da reciprocidade. Embora Telêmaco apresente o caso como particular, Odisseu por ser rei estava ligado por laços de lealdade com toda a comunidade, que deveriam ser recíprocos. Odisseu sempre fora leal e lhano com seu povo e agora esse virava as costas para ele. Agindo assim, o povo rompe com princípio da reciprocidade que deve embasar a relação entre ele e seu rei. Telêmaco, Haliterses e Mentor buscam em seus discursos mobilizar apoio contra os pretendentes, 
transformando uma questão que, de início, é apresentada como particular, em uma questão coletiva, envolvendo a todos. Nos parece que muito mais do que uma clara distinção do que seria público e particular, por se tratar de um assunto que envolve a casa real, haja uma confusão entre essas duas esferas. A questão é particular para Telêmaco, pois envolve a destruição da sua casa, do seu sustento, mas suas conseqüências são públicas, pois a vingança, por esses atos, afetaria toda comunida$\mathrm{de}^{11}$.

Mas se a questão também se apresenta como de alçada do povo, pela lealdade que esse devia a Odisseu, qual motivo o mantém passivo? Seria realmente por conivência, como alude Telêmaco? Ou seria por medo, como podemos inferir das palavras de Evenor que, respondendo a Mentor, diz que mesmo a gentes mais numerosas seria difícil enfrentar os pretendentes. Mas se o povo não seria forte suficiente para enfrentar os pretendentes, por que eles temem a sua reação na segunda reunião, a que realizam sem a presença de mais ninguém na praça de Ítaca?

A posição de Calhoun de considerar que a quase totalidade da comunidade de Ítaca estaria relacionada por laços de parentescos com pretendentes, embora seja um bom argumento, também apresenta seus problemas. Ela nos levaria a aceitar a acusação de conivência feita por Telêmaco, mas o problema estaria em como entender, por exemplo, as palavras de Mentor, afirmando que o povo deve lealdade a Odisseu. Nesse caso, estaríamos diante de uma situação difícil e equacionar: a quem o povo deveria prestar fidelidade? Aos seus parentes ou ao seu rei? Todas essas linhas de interpretação nos levam por caminhos interessantes, porém a ado-

\footnotetext{
${ }^{11}$ Esse padrão parece também ocorrer na llíada, na qual o castigo decorrente dos erros de Agamêmnon recaem sobre todo o exército. A mesma coisa poderíamos observar em relação às conseqüências do comportamento de Páris.
} 
ção de qualquer uma delas, como explicação definitiva para o comportamento do povo nessas assembléias, implica deixar de lado, obliterando-as, as inconsistências que cada uma delas evidencia nas outras que se lhe opõem.

Um ponto de vista fecundo é o de considerar o texto homérico como um todo coeso e apreciá-lo a partir de um todo cujas partes se integram na trama de maneira funcional, uma composição na qual seus elementos se ligam de forma a darem sentido uns aos outros. Assim, julgamos que uma forma de análise proveitosa é a de tomar as duas assembléias como um conjunto que exerce uma função determinada na condução da narrativa. É nesse aspecto que consideramos frutífera a observação de Heubeck de que, desde o início da narrativa, a trama é montada também no sentido de preparar a futura reconciliação entre as partes conflitantes. O sangue derramado por Odisseu, ao matar os pretendentes, não poderia desembocar em um ciclo de retaliações de ambos os lados, pois o seu retorno não implica somente no reencontro com os seus familiares, mas também a recuperação de seu reino. Odisseu como um rei Ihano e justo não poderia governar pela força, portanto a paz teria que ser restabelecida, reatando desse modo os vínculos que unem o rei ao seu povo.

Se prestarmos atenção às palavras de Haliterses, notamos que ele, ao justificar sua posição, de que eles não deveriam lutar contra Odisseu, não menciona que os pretendentes morreram por terem praticado ações vis, responsabilizando-os pela própria morte, mas sim responsabiliza os presentes na assembléia, dizendo que a morte dos pretendentes tinha sido responsabilidade de seus próprios pais que não puseram fim às atitudes insensatas de seus filhos. Assim notamos que a fala de Telêmaco, na primeira assembléia, longe de ser uma manifestação de sua ingenuidade, como aponta Heubeck, pelo contrário se insere no contexto maior da trama que visa responsabilizar os próprios familiares dos pretendentes pela suas mortes. 
Após Eupites ter dito que Odisseu havia matado seus filhos, Haliterses não responde dizendo que eles morreram pois eram culpados, mas sim que a responsabilidade das mortes era exatamente daqueles que agora queria vingá-las. Assim não Ihes caberia vingança por mortes que eles próprios seriam responsáveis. Dessem modo, se os presentes na assembléia foram ofendidos, nas mortes de seus filhos e irmãos, foi pela própria insensatez, o que os coloca no mesmo patamar dos homens que Odisseu perdeu na volta de Tróia, que morreram pela própria estupidez, pois foram advertidos a não tocarem no rebanho de Hélio. As palavras de Haliterses preenchem de sentido as de Telêmaco, responsabilizando o povo de Ítaca como conivente a tudo que acontecia.

A fala de Haliterses acusando os presentes na assembléia de não terem dado ouvidos nem a ele, nem a Mentor, pondo fim à monstruosidades praticadas por seus filhos, sugere que o grupo de parentes dos pretendentes deveria, pelo menos formar uma parte significativa da "assembléia de Telêmaco", senão a quase totalidade. Aqueles à quem Mentor pediu lealdade a Odisseu compunham uma parte significativa da parentela dos pretendentes que na "Assembléia da Vingança" queriam reparação. Talvez isso explique o silêncio deles na primeira assembléia. Entre manter-se fiel à Odisseu ou aos membros de seu oîkos, optam pelos membros de suas próprias casas. Assim estaríamos diante do choque entre dois princípios organizativos que marcaria a sociedade homérica: o da organização patriarcal e o da lealdade que se deve prestar a casa real, principalmente quando seu rei é bom e justo, o que implica no princípio da reciprocidade que deve ligar o rei e seu povo. Porém se essa explicação permite relacionar a "Assembléia de Telêmaco" a "Assembléia da Vingança" , como poderíamos entender a posição do povo (dêmos) aludida na "Reunião dos Pretendentes"? Por que nela, o povo que parece se compor de uma boa parte 
de parentes dos próprios pretendentes ficariam contra eles, diante da tentativa de assassinato de Telêmaco? Seria a gravidade do crime que faria de uma tentativa de assassinato uma pronta resposta da comunidade enquanto a destruição da casa de Telêmaco seria tolerada?

A exploração que fizemos até aqui nos permite colocar uma pergunta essencial: essas três reuniões realizadas na agorá representariam um cenário coerente ou modelos organizativos de sociedades distintas, amalgamadas no poema pelo processo de composição da poesia oral? Em que medida o comportamento do povo, na primeira reunião, diferenciar-se-ia do comportamento apresentado nas duas seguintes?

Se é difícil identificar a natureza social do povo homérico, consideramos que podemos evidenciar a justaposição de dois princípios organizativos que entram em choque, se opondo na querela de Ítaca. Na Assembléia de Telêmaco, temos o princípio da lealdade que o povo deve ao seu rei. Na "Assembléia da Vingança", o princípio da lealdade familiar na vingança de sangue.

O silêncio do povo, na primeira, mostra-nos que o princípio da lealdade ao bom rei não foi forte suficiente para mobilizá-lo contra os pretendentes. Quem seria esse povo e suas relações com os pretendentes? Vimos que não é possível tecer comentários conclusivos sobre essa questão, embora consideremos plausível, como mostramos acima, tomá-lo como sendo formado por grupos de parentelas ligados aos pretendentes. Na terceira reunião, a "Assembléia da Vingança", ao se retratar o debate ocorrido nela, temos os mesmo esquema formal de composição. De um lado, temos Eupites tentando mobilizar o povo contra Odisseu (na primeira é Telêmaco tentando mobilizar o povo contra os pretendentes); de outro, temos Haliterses ten- 
tando desmobilizá-lo para a ação (na primeira esse papel é dado aos pretendentes). Quando comparamos os argumentos apresentados por Telêmaco e Eupites - os dois que estão no papel de mobilizadores - percebemos que, enquanto o primeiro acentua a questão da lealdade do povo ao seu rei, o segundo argumenta nos quadros do "tema da vingança", apresentando a ação como uma questão que ocorre no âmbito do código moral que estabelece laços de solidariedades no interior do oîkos, com Eupites clamando que os filhos e os irmãos mortos deveriam ser vingados. É o princípio da organização patriarcal da comunidade, que se evidencia, no registro que a narrativa opera do motivo apresentado para que os parentes não lutem contra Odisseu. Haliterses não apela à solidariedade que o laós deve ao seu chefe, mas infunde nele o medo, alegando que um deus estava ao lado de Odisseu. É devido ao medo da ajuda divina recebida por Odisseu, que parte da assembléia debanda.

Tanto na primeira reunião, como na terceira, parece estarmos diante de uma sociedade em que seu povo se movimenta basicamente nos quadros de uma sociedade patriarcal em que os laços de sociabilidade se definem em relação às obrigações que cada indivíduo tem para com sua própria casa. É essa comunidade que Telêmaco chama em apoio de sua casa, e não obtém resposta. No plano da narrativa épica, a dos heróis e dos deuses, a realeza de Odisseu triunfa, porém no plano da comunidade, da estrutura social que Homero apresenta como pano de fundo de sua narrativa, ela estava destinada ao fracasso. 


\section{BIBLIOGRAFIA}

ADKINS, A.W.H. Homeric values and homeric society. THE JOURNAL OF HELLENIC STUDIES, v.XCI, p.1-14, 1971.

ANDREWS, A. Phratries in Homer. Hermes, Vol. 89, No. 2 (Mai., 1961), 129-140.

AUSTIN, M.; VIDAL-NAQUET. Economia e Sociedade na Grécia Antiga. Tradução Antonio Gonçalves e Antonio Nabarrete. Lisboa: Edições 70, 1972. 363 p.

AUSTIN, N. Archery at the Dark of Moon - Poetic Problems in Homer's Odyssey. 1975

BAKKER, E.J. Discourse and Performance: Involvement, Visualization and "Presence" in Homeric Poetry. CLASSICAL ANTIQUITY, v.12, n.1, p.1-29, April 1993.

BENVENISTE, E. O Vocabulário das Instituições Indo-Européias - Economia, parentesco e sociedade. Campinas: Editora Unicamp, 1995a. Vol.1.

BENVENISTE, E. O Vocabulário das Instituições Indo-Européias - Poder, direito e religião. Campinas: Editora Unicamp, 1995b. Vol.2.

BREMMER, J.N. A Homeric Goat Island (Od.9.116-41). The Classical Quartely, New Series, Vol.36, No. 1 (1986), 256-57.

BOUVIER, D. Le Sceptre et la Lyre: L'lliade ou les Héros de la Mémoire. Grenoble : Million, 2002

BOWDEN, H. Hoplites and Homer: Warfare, hero cult, and the ideology of the pólis. In Jhon Rich and Graham Shipley (Ed.). War And Society in the Greek World.

BRIQUEL, D. Des comparaisons animales homeriques aux guerriers fauves indoeuopeens. Kernos 8 (1995).

BURCKHARDT,J. Historia de la Cultura Griega. Trad. Eugenio Imaz. OBRAS MAESTRA

BYRE, C.S. Narration, Description, and Theme in The Shield of Achilles. The Classical Journal. Cidade, v.88, No.1, p. 35-42, 1992.

BYRE, C.S. The Rhetoric of Description in the Odyssey 9.116-41. The Classical Journal. V.88, No.1, p. 35-42, 1992.

CALHOUN, G.M. Classes and Masses in Homer II. Classical Philology, No 4 (Oct., 1934), 301-316.

CARTLEDGE, P. Hoplites and heroes: Sparta's contribution to the technique of ancient waefare. JHS, 97 (1977): 11-27.

CLARKE, M. Between Lions and Men: Images of the Hero in the Iliad. Greek-Romam and Byzantine Studies, Durham, v.36, No.2, p. 137-160, 1995.

CLAY, J.S. Goat Island: Od.9.116-141. The Classical Quartely, New Series, Vol.30, No. 2 (1980), 261-264. 
CLAY,J.S. The Wrath of Athena. New York: Rowman \& Littlefield Publishers,

COEN, M. Tradeuction Homeric et Phénomène de Traduction. LES ÉTUDES CLASSIQUES, tomo LVI, p.15-25, 1988.

COFFEY, M. The Function of Homeric Simile. AJPh, V.78, p.113-32, 1957.

COSSET, E. Esthétique et Systême formulaire dans L'lliade. LES ÉTUDES

CLASSIQUES, tome LIII, n.3/4, p. 331-340, 1985.

DETIENNE, M. La Phalange,in Problèmmes et Controverses.. In Jean-Pierre Vernant (org). Problèmes de la guerre en Grèce ancienne. Paris-La Haye, Mouton \& CO

DONLAN, W. Changes and Shifts in the Meaning of Demos in the literature of the Archaic Period. La parola del Passato, vol. 135 (1970), 381-95.

DONLAN, W. The Structure of Authority in the Iliad. Arethusa 12 (1979), 51-70.

DONLAN, W. The Aristocratic Ideal in Ancient Greece. In: The

Aristocratic Ideal and Selected papers. Coronado Press, 1980.

DONLAN, W. The Social Groups of Dark Age Greece. Classical Philology, Vol. 80, No.4 (Oct., 1985), 203-308.

DONLAN, W. The Pre-State Community in Greece. Symbolae Osloenses, No 67 (1989) 5-29.

DRIESSEN,J. Homère et les tablettes en linéaire B. L'ANTIQUITÉ CLASSIQUE, tome LXI, p.5-37, 1992.

DUBY, G. A História Continua. Trad. Clóvis Marques. Rio de Janeiro: Jorge Zahar Ed.,1993.

EDWARDS, M.W. Homer poet of lliad. London: The Jhons Hopkins Press Itd, 1988.

FARRAR, C. The origins of democratic thinking. Cambridge: Cambridge University Press, 1990.

FINNEGAN, R. Oral Poetry: Its Nature, Significance and Social Context. Cambridge.

FINLEY, M. Mito, Memória e História. In:

Paulo: Livraria Martins Fontes Editora, 1989. p. 3-27.

FINLEY, M.I. O mundo de Ulisses. Trad. Armando Cerqueira. Lisboa: editorial Presença, 1998.

FOUCAULT, M. A ordem do discurso. Trad.Laura Fraga de Almeida Sampaio. São Paulo: Edições Loyola, 2000.

FRIEDRICH, R. On the Compositional Use of Similes in the Odyssey. AJPh, 1981.

FRIEDRICH, R. Heroic Man and Polymetis: Odysseus in the Cyclopeia. Greek-Romam and Byzantine Studies. V.36, No.2 (Summer 1987), 121-33.

SALE, W.M. The Government of Troy: Politics in the lliad. Greek-Romam and Byzantine Studies. V.35, No. 1 (Spring 1994), 5-102. 
GADAMER, H.G. Verdade e Método I - Traços fundamentais de uma hermenêutica filosófica. Trad. Flávio Paulo Meurer. Petrópolis: Vozes, 1997.

GAGARIN, M. Drakon and Early Athenian Homicide Law. Cidade: Yale University, 1981.

GEDDES, A.G. Who's who in Homeric society. The Classical Quarterly. Oxford, v. XXXIV, No.1, p.17-36, 1984.

GINZBURG, C. Relações de Força - História, retórica e prova. Trad. Jônata Batista Neto. São Paulo: Companhia das Letras, 2002.

GOMME, G.L. On the Evidence for Mr.McLennan's Theory of the Primitive Humam Horde. The Journal of the Antropological Institute of Great Britain and Ireland. Vol. 17 (1888), 118-134.

GRAY, D.H.F. Metal Working in Homer. THE JOURNAL OF HELLENIC STUDIES, v.LXXIV-LXXV, p.1-15, 1954-55.

GRIFFTHS, A. Non aristocratic elements in the archaic poetry. In Anton Powell (ed.). The Greek World , p.85-103.

HALVERSON, J. Social Order in the Odissey. In: Emlyn-Jones, C. et al. (ed.) Homerreadings and images. Local: editora, ano, p.176-190.

HALVERSON, J. The Succession Issue in the Odyssey. GREECE AND ROME. Cidade, v. XXXIII, n.2, p.119-128, october 1986

HAMMER, D. The politics of the lliad. The Classical Journal. Cidade, v.94, No.1, p. 130, 1998.

HAUBOLD, J. Homer's People, Epic Poetry and Social Formation, Cambridge, 2000.

HAVELOCK, E. Prefácio a Platão. Tradução Enid Abreu Dobránzky. Campinas:

Papirus, 1996.

HERNANDEZ, P.N. Back in the Cave of the Ciclops. American Journal of Philology, 121 (2000), 345-366.

HEUBECK, A; WEST, S. A comentary on Homer's Odyssey. Oxford: Clarendon press, 1990, V.1 -3.

JULIEN, A. A coletividade na llíada. 2001. 134 f. Dissertação (Mestrado em História Social). FFCLH, Universidade de São Paulo, São Paulo.

KELLER, A.G. Sociology And The Epic. The Americam Journal of Sociology, Vol. 6, No. 2 (Sep., 1900), 267-271.

KELLER, A.G. Sociology And Homer. The Americam Journal of Sociology, Vol. 9, No. 1 (Jul., 1903), 37-45.

KIRK, G.S. War and warrior in the homerics poems. In Jean-Pierre Vernant (org). Problèmes de la guerre en Grèce ancienne. Paris-La Haye: Mouton \& CO,

KIRK, G.S. The Search For The Real Homer. Greece \& Rome, 2nd Ser, Vol. 20, No 2 (Oct., 1973), 124-139. 
KIRK, G.S. The Song of Homer. Cambridge, 1962.

KIRK, G.S. MYTH - its meaning \& functions in ancient \& other cultures. London: Cambridge University Press, 1998.

KNOX, M.O. House and Palace in Homer. THE JOURNAL OF HELLENIC STUDIES, v. XC, p.117-139, 1970.

LANGLOIS, C.V; SEIGNOBOS, C. Introdução aos Estudos Históricos. Trad. Laerte de Almeida Morais. São Paulo: Editora Renascença S.A., 1946.

LAZENBY, J.F. AND WHITEHEAD, D. The myth of the hoplite's. THE CLASSICAL QUARTERLY, v.XLVI, n.1, p.27-33, 1996.

LEAF, W. Homer and History. London, 1915.

LORD, A.B. Composition by Theme in Homer and Southslavic Epos. Transactions and Proceeding of the American Philological Association, Vol.82 (1951), 71-80.

LORD, A.B. The singers of Tale. London: Havard University Press, 1960. 307 P.

MCGLEW, J.F. Royal Power and the Achaean Assembly at Iliad 2,84-393. Classical Antiquity. California, v.8, No.2, p.283-295, 1989.

MINCHIN, E. The poet appeals to his muse. THE CLASSICAL JOURNAL, v.91, n.1, p.25-33, October-november/1995.

MONDI, R. The Homeric Cyclopes: Folktale, Tradition, and Theme. Transctions of the American Philological Association, Vol. 113 (1983), 17-38.

MORRIS, I. The use and abuse of Homer. CLASSICAL ANTIQUITY. Berkeley: University of California press, v.5, n.1, p. 81-1138 april 1986.

MOSSÉ, C. Dicionário da Civilização Grega. Trad. Carlos Ramalhete. Rio de Janeiro: Jorge Zahar Ed., 2004.

Nagy, G. The Shield of Achilles: Ends of the lliad and Beginnings of the Polis. In: Susam Langdon (ed.). New Light on a Dark Age: Exploring The Culture of Geometric Greece. Columbia: U.of Missouri Press 1997), 194-207.

NAGY, G. Greek Mythology and Poetics. Ithaca: Cornell University Press, 1990.

NAGY, G. The Best of Achaeans. London: The Johns Hopkins University Press, 1979.

NAGT, G. Homeric Questions. Austin: University of Texas Press, 1991.

NILSON, M. Homer and Mycenae. London, 1933; repr. New York, 1968. Oxford, v.XXXIII, No.2, p. 119-128, 1986.

OSBORNE, R. Homer's Society. In: Robert Fowler (ed.). The Cambridge Companion To Homer. Cidade: Cambridge University Press, ano.

PEEK, P.S. Propriety, Impropriety, and the Gaining of Kleos in the Phaiakian Episode. Vol. 43, No. 4 (2002/3), 309-39.

PIRES, F.M. Mithistória. São Paulo: Humanitas, 1999. 
POSNER, R.A. The Homeric Version of Minimal Estates. Ethics, Vol.90, No 1 (Oct., 1979), 27-46.

POSTLETHWAITE, N.. Thersites in the lliad. Greece \& Rome. Oxford, v.XXXV, No.2, p. 123-135, 1988.

RAAFLAUB, K.A. HOMERIC SOCIETY. In I.Morris, B.Powel (ed.)

ROSE, P.W. Class Ambivalence en the Odyssey. In: Emlyn-Jones, C. et al. (ed.) Homer - readings and images. Local: editora, ano, p.192-209.

ROSIVACH, V.J. THE CLASSICAL JOURNAL, v.76, n.4, p.289-297, april-may/1981.

RUNCIMAN, W.G. Origins of States: The Case of Archaic Greece. Comparative Studies in Society and History, Vol.24, No.3 (Jul., 1982), 351-377.

RUSSO, J. A; FERNÁNDEZ-GALIANO, M; HEUBECK, A.. Commentary on Homer's Odyssey, V.III, books XVII-XXIV.

SALE, W.M. The Government of Troy : Politc in the lliad. Greek-Roman and Byzentine Studies, Vol. 35, No 1 (spring, 1994), 5-102.

SEAFORD, R. Reciprocity and ritual - Homer and Tragedy in the developing city States. New York: Oxford University Press, 2000. 1a ed.1994.

SEGAL, C. Singers, heroes, and gods in the Odyssey. New York: Cornell University Press, 1994

SCHEID-TISSINIER, E. Laos et dèmos, le peuple de l'épopée. L'Antiquité Classique. Bruxelles, tome DEEL LXXXI, p.1-26, 2002.

SCHLEIERMACHER, F.D.E. Hermenêutica - arte e técnica da interpretação. Trad. de Celso Reni Braida. Bragança Paulista: Editora Universitária São Francisco, 2003.

SCHNAPP-GOURBEILLON, A. Lions, héros, masques - la representation de l'animal chez homère. Paris : François Maspero, 1981.

SEGAL, C.P. The Phaeacians and the Symbolism of Odysseu's Return. Arion, 1, 4 (1962).

SHEWAN, A. The Scheria of the Odyssey. The Classical Quartely. Vol. 13, No. 2 (apr., 1919), 57-67.

SNODGRASS, A.M. An Historical homeric society? JHS, 1994.

STAGAKIS, G. Homeric Warfare Practices. História, v.34, p. 129-152, 1985.

STANFORD, W.B. The Odyssey of Homer. London, 1954.

TAPLIN, O. The Shield of Achilles Within the lliad. Greece \& Rome, 2nd Ser, Vol. 27, No 1 (Apr., 1980), 1-21.

THALMANN, W.G. Conventions of Form and Thought in Early Greek Epic Poetry. London: The Johns Hopkins University Press, 1984. 263 p. 
THALMANN, W.G. Thersites: Comedy, Scapegoats and Heroic Ideology in the lliad. Transctions of the American Philological Association, Vol. 118 (1988), 1-28.

THORTON, A. People and Themes in Homer's Odyssey. London: Methuen \& Co.Itda, 1970.

TRABULSI, J.A.D. Ensaio sobre a mobilização política na Grécia Antiga. Belo Horizonte: Ed.UFMG, 2001. 145 p.

TRABULSI, J.A.D. Religião e política na Grécia, das origens até a pólis aristocrática. Revista Brasileira de Estudos Clássicos. São Paulo, v.5/6, p.133-147, 1992/1993.

VANSÉVEREN, S. La Formule Homérique, problèmes de définition. LES ÉTUDES CLASSIQUES, v.66, p. 225-236, 1998.

VIDAL-NAQUET, P. O Mundo de Homero. Trad. Jônatas Batista Neto. São Paulo: Cia das Letras, 2002.

WAKE, C.S. The Primitive Human Horde. The Journal of the Antropological Institute of Great Britain and Ireland. Vol. 17 (1888), 276-82.

WEES, H.V. Leaders of men? Military organization in the lliad. The Classical Quarterly, Oxford, v. XLVI, No.1, p.285-303, 1996.

WESS, H.V. The Homeric way of war: The lliad and Hoplite Phalanx (II). Greece \& Rome, Oxford, v.XLI, No.2, p. 131-154, 1994.

WESS, H.V. The Homeric way of war: The Iliad and Hoplite Phalanx (I). Greece \& Rome, Oxford, v.XLI, No.1, p. 1-17, 1994.

YAMAGATA, N. $\alpha 2 v \alpha \xi$ and $\beta \alpha \sigma \imath \lambda \varepsilon \dot{\varepsilon} v \varsigma$ in Homer. The Classical Quarterly. Oxford, v. XLVII, No.1, p.1-14, 1997. 